\title{
تأثير ظروف عملية المرسرة على تحسين خواص أقمشة هكملات الملابس المببوغة بالصبغات الطبيعية
}

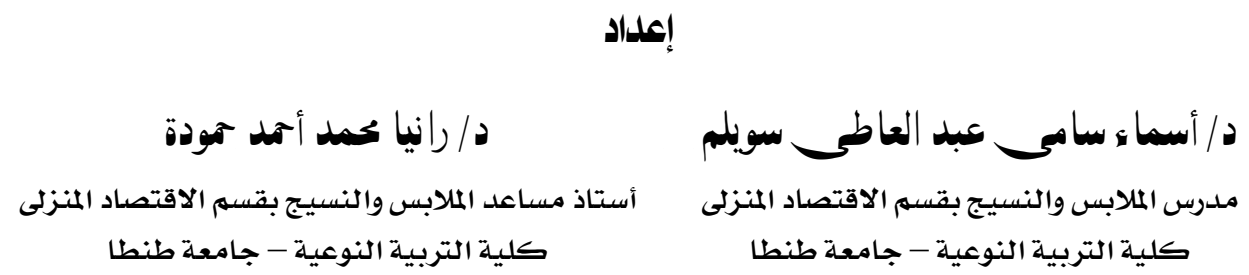

مجلة بحوث التربية النوعية ـ جامعة المنصورة

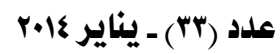


ـــأثير ظروف عملية المرسرة على تحسين خواص أقهشة مكملات الملابس المصبوغة بالصبغات الطبيعية ـ- 


\title{
تأثير ظروف عملية المرسرة على تحسين خواص أقمشة مكملات الملابس المببوغة بالصبغات الطبيعية
}

\author{
(إعداد \\ د/رانيا محمد أحمد حمودة** ت \\ * أسماء سامعبد العاطحسويلم
}

\begin{abstract}
تبرز الأهمية الكبرى لصناعة الغزل والنسيج والتريكو وكذلك صناعة التجهيز ( متضمنا

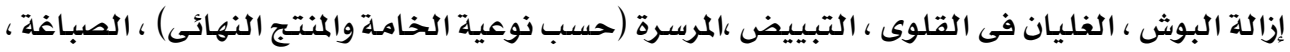

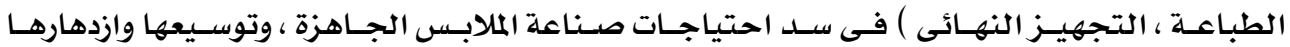

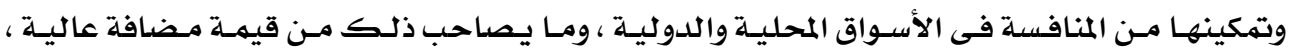

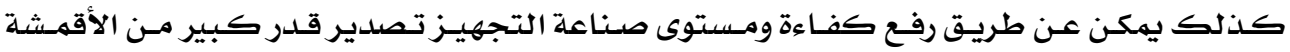

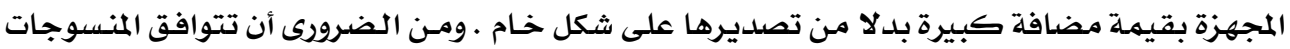

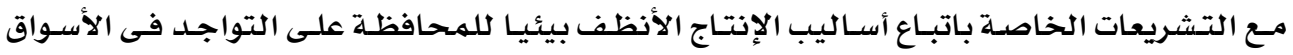
وزيادة القدرة على المنافسـة .

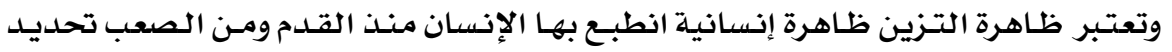

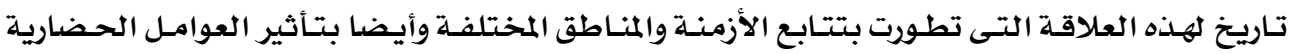

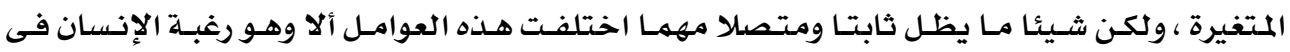

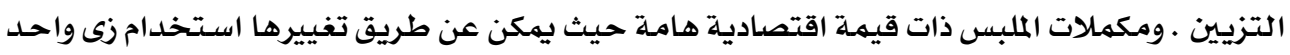

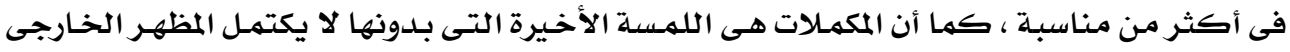

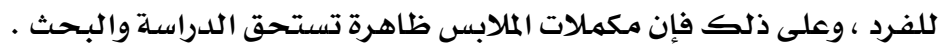

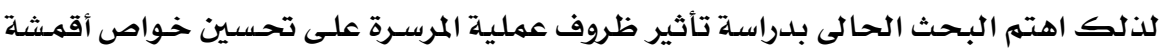

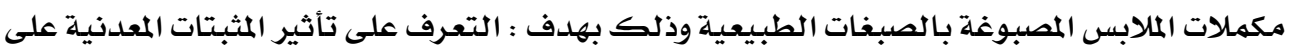

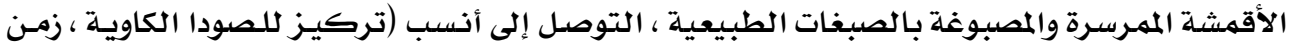

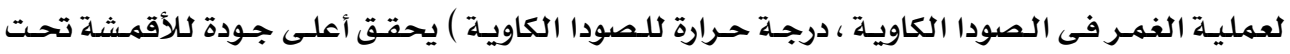

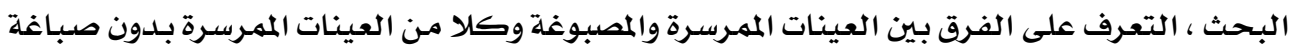
والعينات المصبوغة بدون مرسرة.

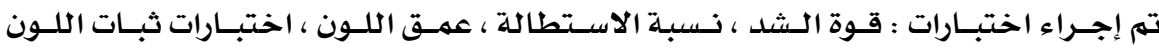

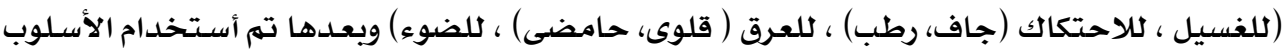

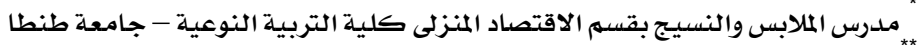

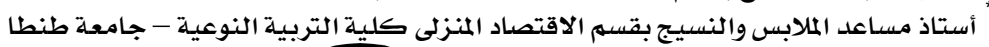




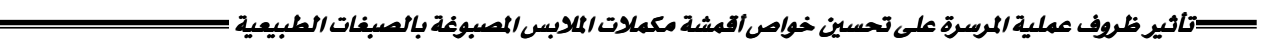
الاحصائى المناسب وإجراء تقييم الجودة لنتائج هذه الاختبارات ، وكانت أهم النتائج التى توصل لها البـحث :

ا- العينـات الممـرسـرة والمصبوغة باستخدام مثبـت الكروم Chrome حققت أعلى قيم للخواص

$$
\text { المقاسـة . }
$$

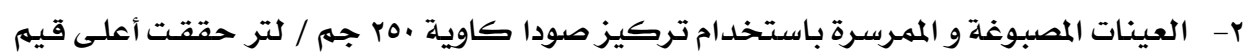

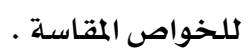

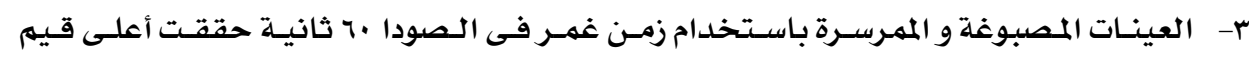

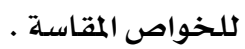

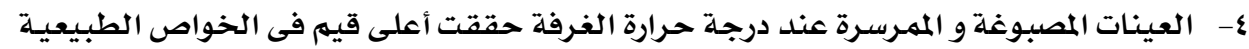

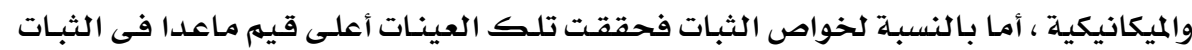

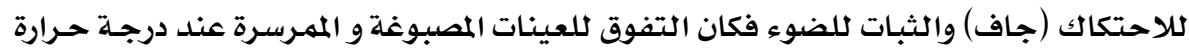

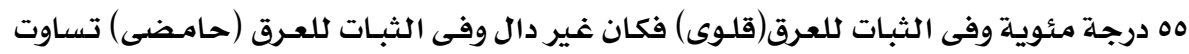

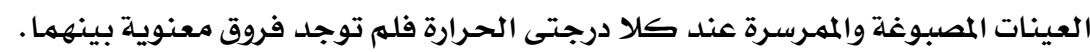

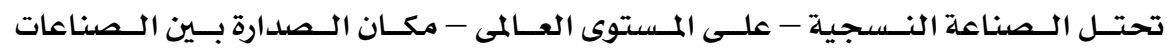

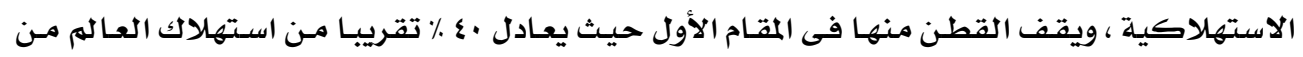

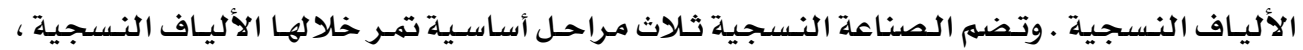

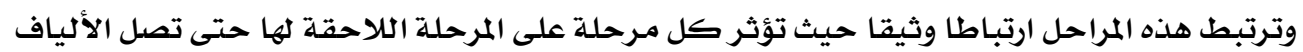

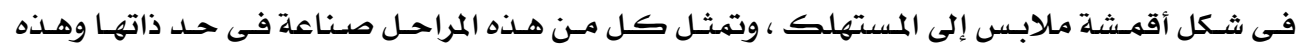

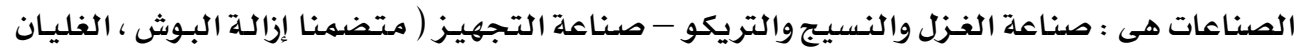

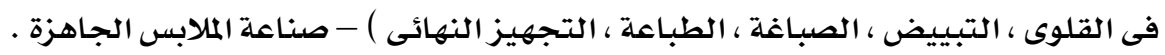

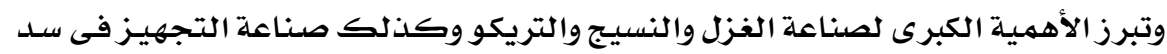

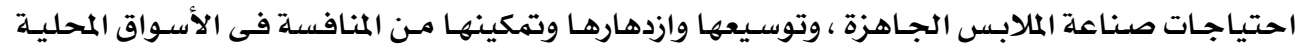

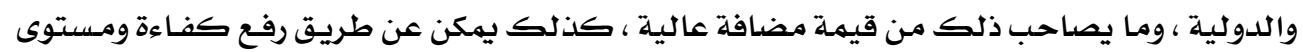

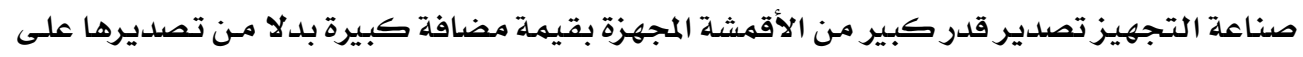
شكل خام .

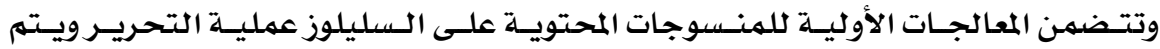

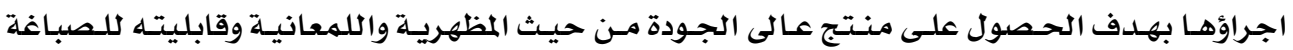

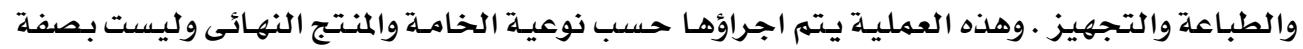
روتينية كما هو الحال فى باقى المعالجات الأولية .

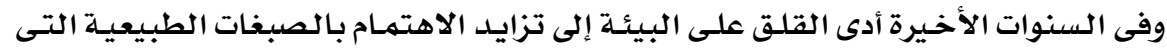

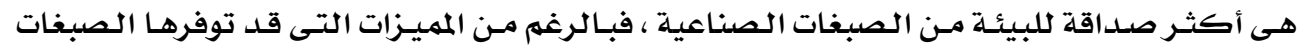




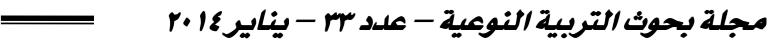

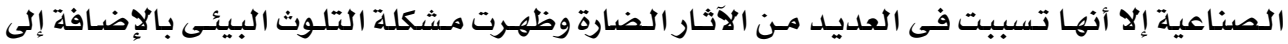

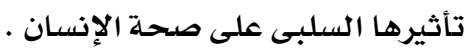

ولاشك أن مكملات الملابس لها أثر كبير على المظهر الملبسى ، هـذا إلى جانب اعتبارهـا مـن

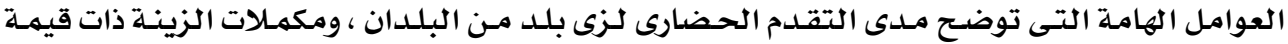

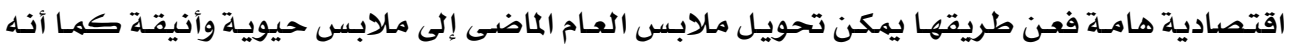

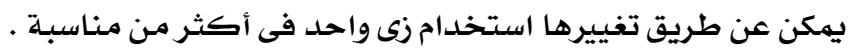
لهـذا تم اختيـار موضـوع البحـث تحست عنـوان : " تـأثير ظـروف عمليـة المرسـرة علسى تحسـين

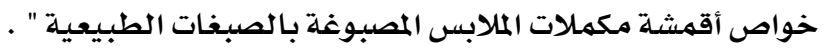

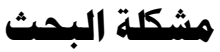
تظهر فى التساؤلات التالية :

1- هل تحسن عملية المرسرة من خواص أقمشة مكملات الملابس المصبوغة بالصبغات الطبيعية ؟

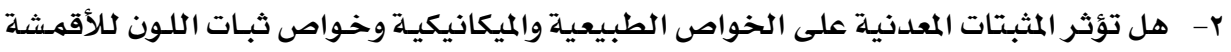

$$
\text { تحت البحث ؟ مل مأر المئينات }
$$

ب- ما أثر اختلاف تركيز الصودا الكاوية فى عملية المرسرة على خواص الأقمشة تحت البحث ؟

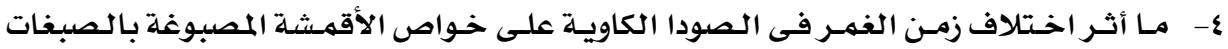

$$
\text { الطبيعية ؟ }
$$

ه- ما دور درجة حرارة الصودا الكاويـة في تحسين خواص الأقمشة تحت البحث ؟

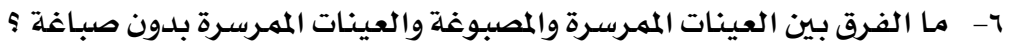

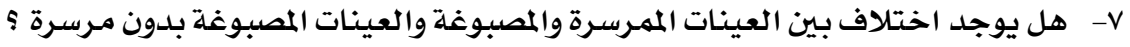

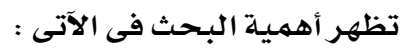

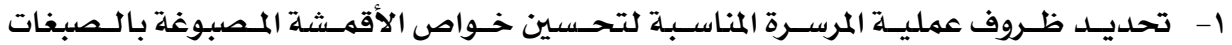

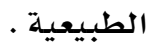

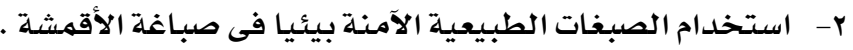

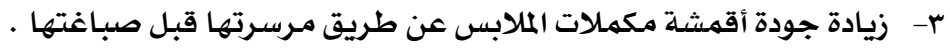

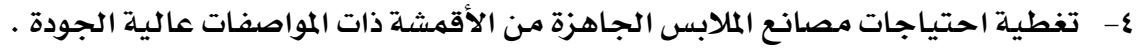

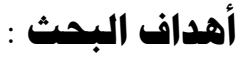

ا- دراسـة تأثير المثبتات المعدنية على الأقمشة الممرسرة والمصبوغة بالصبغات الطبيعية .

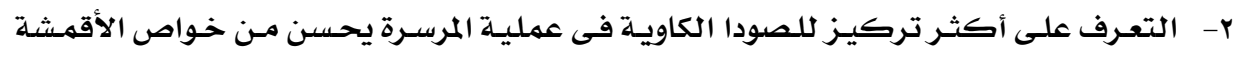

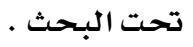

r- التوصل إلى أكثر زمن لعملية الغهر فى الصودا الكاوية يحقق أعلى جودة للخواص المقاسة. 


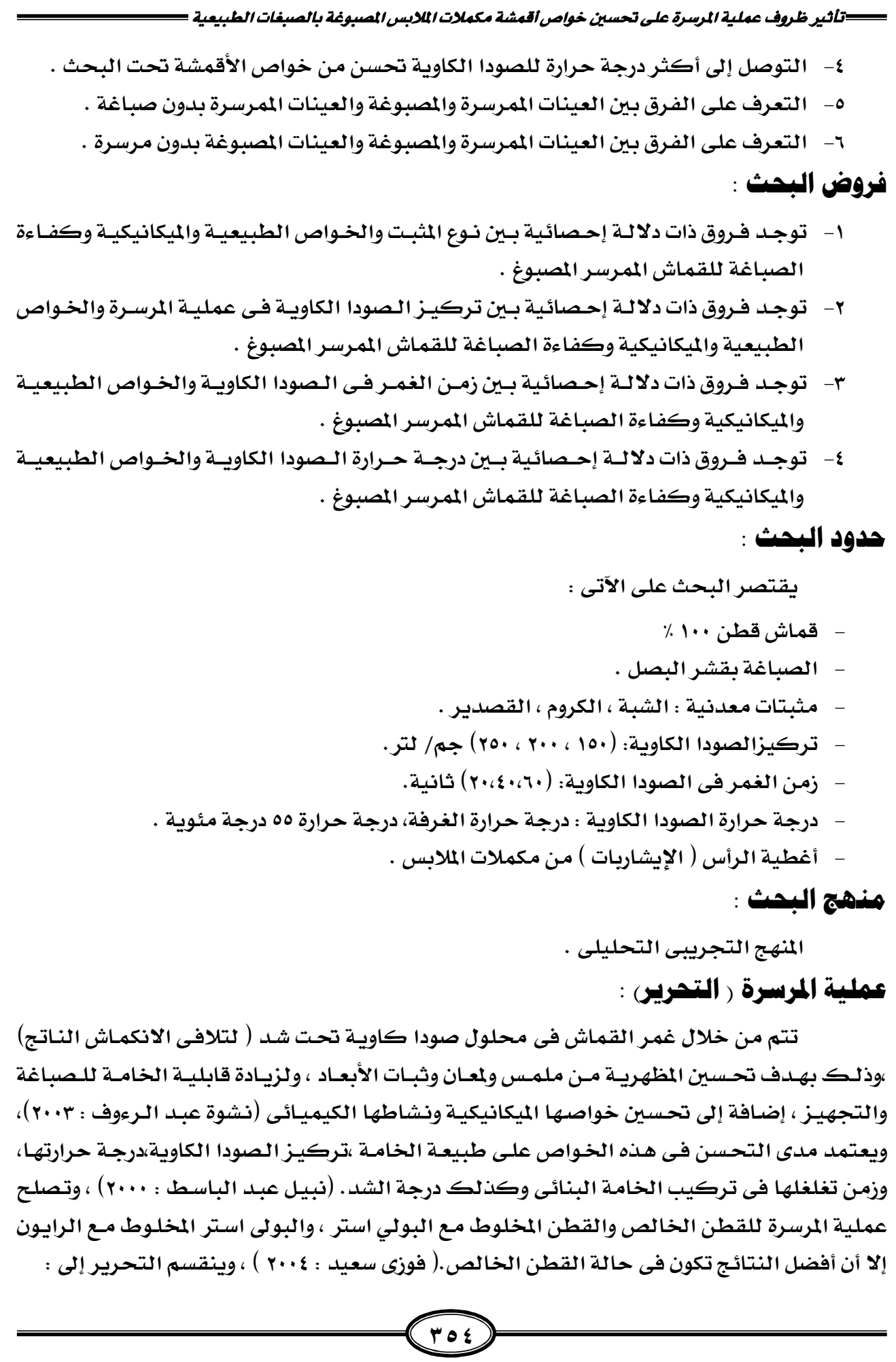


• تحرير كامل : وذلك للحصول على درجة لمعان عالية ، بزيادة تركيز الصودا الكاوية .

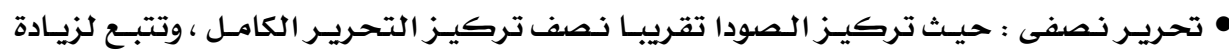

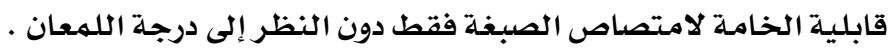
ورغمه أن التحريـر يـأتى بعـد التبيـيض ، إلا أنه يهكن إجراؤهـا على القهـاش الخـام إذا كـان

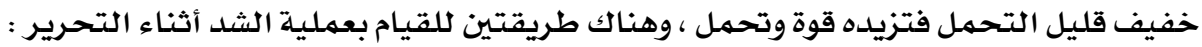

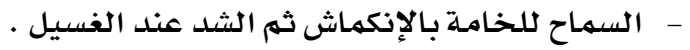

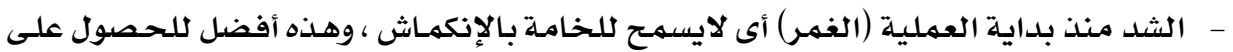

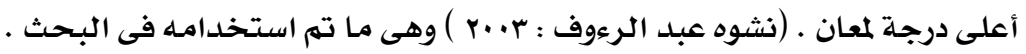

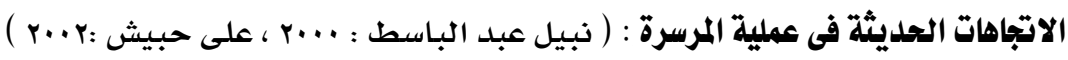

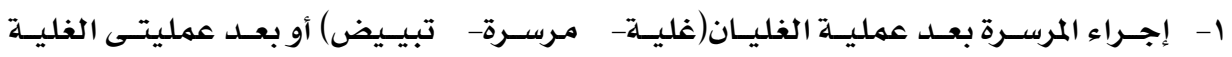

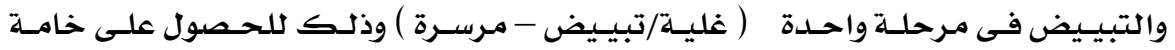

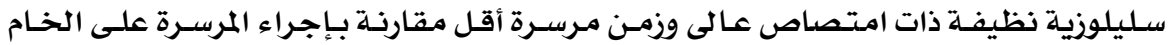

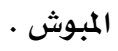

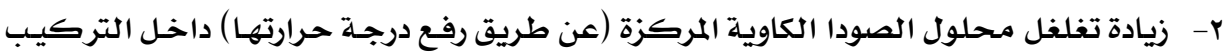

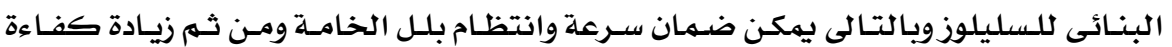

$$
\text { عملية المرسرة . ماتحى }
$$$$
\text { r- دمـج عملية المرسرة والغليان فى القلوى فى مرحلة واحدة . }
$$

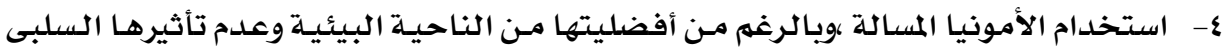

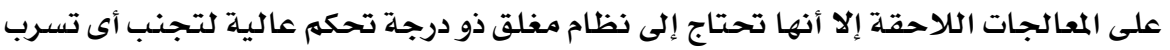

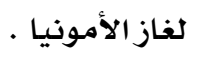

ه- استخدام ما يعرف بنظام الرغوة على القماش الجاف ، ولكنه لا يطبق عمليا .

$$
\text { 7- استرجاع الصودا الكاوية وإعادة استخدامهامها. }
$$

وتجرى عملية المرسرة عادة على المنسوجات أو الخيوط القطنية تحت نسب شد مختلفة وقد

$$
\text { أظهرت الدراسات : ت أجرى }
$$

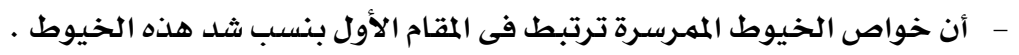

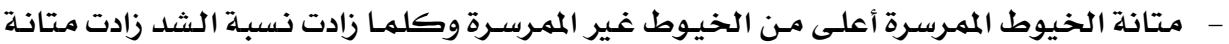

$$
\text { الخيوط الممرسرة. }
$$

- القطن الممرسر يتسهم بتركيب أكثر تجانسا يكفل توزيعا جيدا للقوى على طول الألياف .

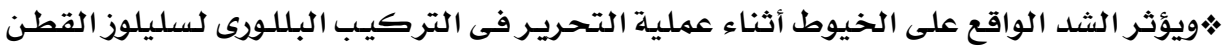

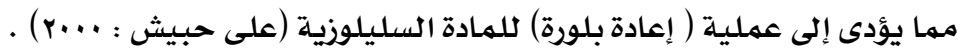


ــأثير ظروف عملية المرسرة على تحسين خواص أقمشة مكملات الملابس المصبوغة بالصبغات الطبيعية ـ هُتغير المرسرة فى نسبة السليلوز المتبلور حيث تنخفض كثيرا عن تلك فى القطن غير الممرسـر

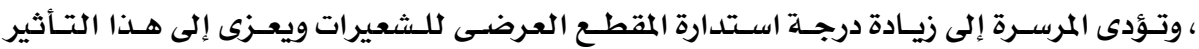

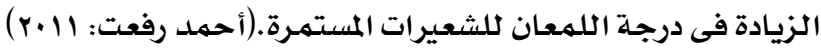

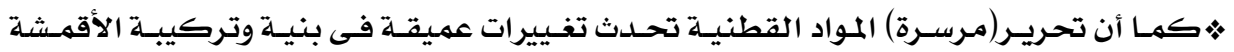

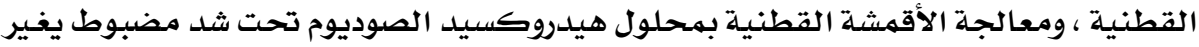

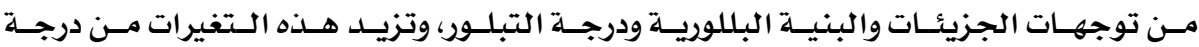

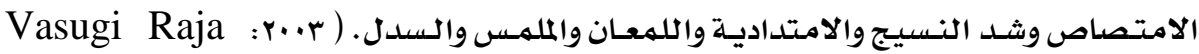
( ,Coimbatore ,V Subramaniam

\section{صباغة المنسوجات :}

هى عملية ريط ألياف الخام بهمادة عضوية ملونـة لها قدرة على الارتبـاط بها والثبـات عليها

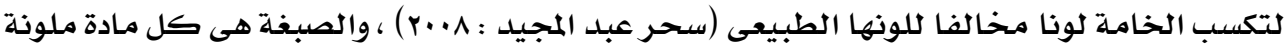

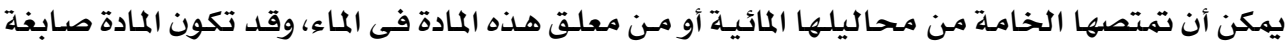

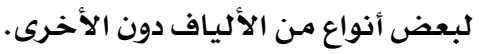

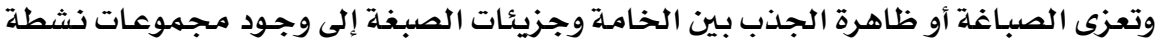

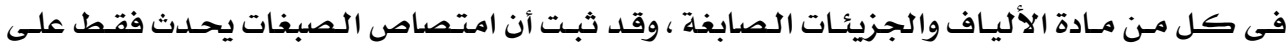

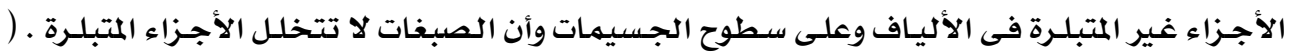

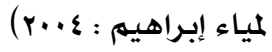

\section{ميكانيكية عملية الصباغة :}

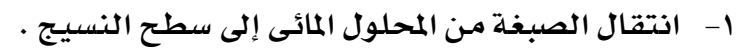

r- ب ادمصاص الصبغة بواسطة السطح الخارجى للنسيج.

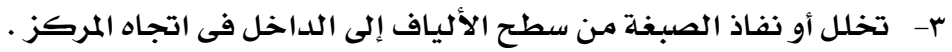

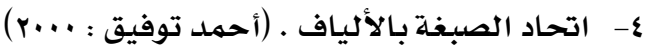

تقسيم الصبغات الطبيعية تبعا لأصل المنشأ :

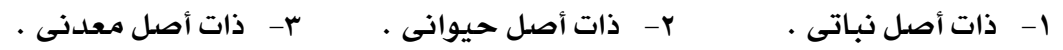

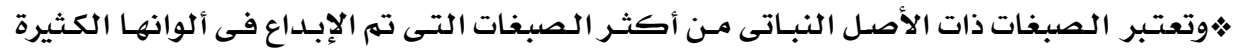

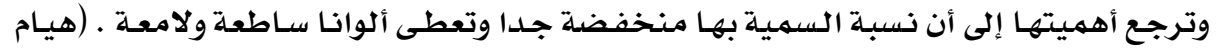

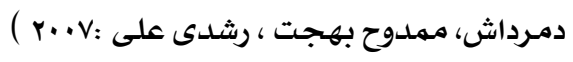

مزايا الصبغات الطبيعية :

1- يتم الحصول عليها من مصادر متجددة .

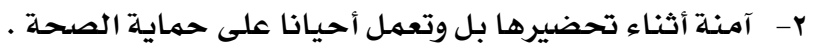

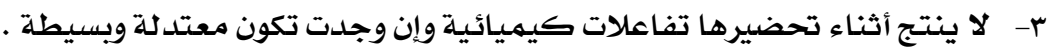




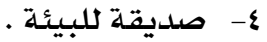

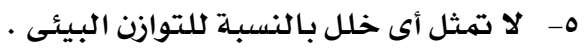

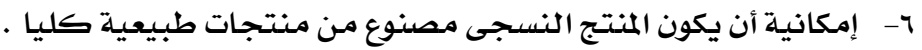

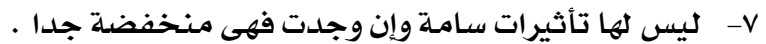

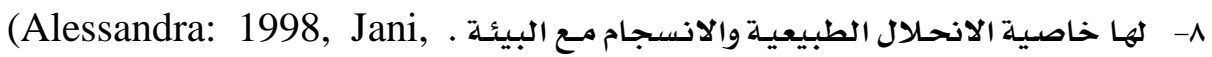

$$
\text { M.L.C.:1999) }
$$

$$
\text { 9- لها مظهر مميز وتعطى تأثيرات كثيرة لألوان نادرة. }
$$

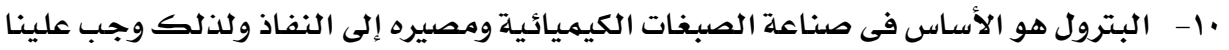

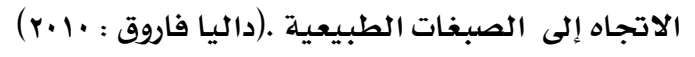

عيوب المببغات الطبيعية :

1- ق قلة المعلومات التكنولوجية الخاصدة باستخلاصها .

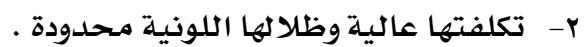

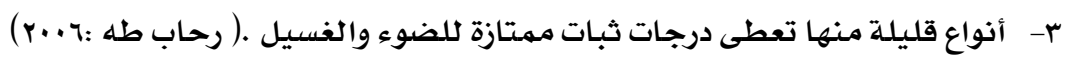

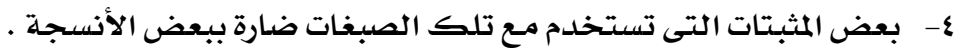

$$
\text { وللحفاظ على التوازن البيئى ينبغى : }
$$

- استخدام المواد المنتجهة للصبغات والتى تعد ذات قيمـة تجارية قليلة .

$$
\text { - تجنب استخدام المواد الخام ذات القيمهة الطبيـة . }
$$

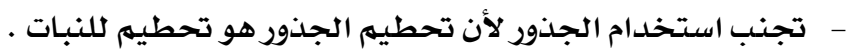

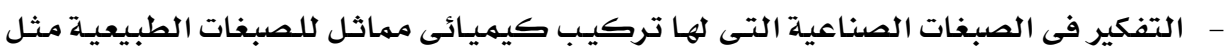

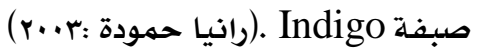

\section{الاتجاهات المديثة فى الصباغة بالصبـغات الطبيدية}

*المعالجة بالبلازما وتأثيرها على الصباغة بالصبفات الطبيعية :

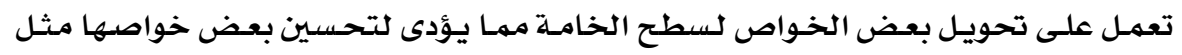

التطريـة- الصبـاغة- دجـة لمعـان الصبغة وخـواص الثبـات ومقاومسة الانكمـاث ، وهـذه الطريقـة آمنــة

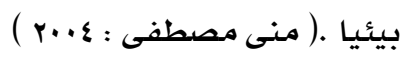

: Supercritical Fluid Carbon Dioxide (SFD) استخدام تكنيك :

هذا التكنيك محبـب للبيئة ويعطى خواص ثبـات جيـدة للضوء والغسيل وشـدة لـون داكنـة

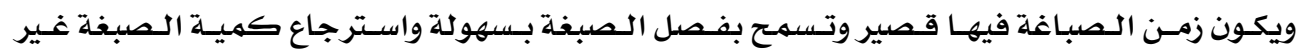
المستخدمدة واستخدلامها مـرة أخرى . 


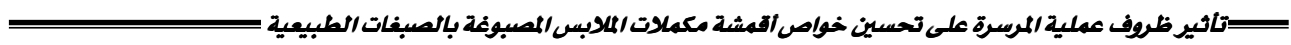
* استخدام حمام الصباغة أكثر من مرة فى عملية الصباغة :

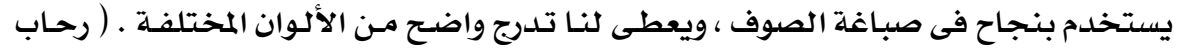

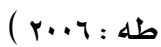
* صباغة القطز بالصبفات الطبيعية (كركم) مع المعالجة بالإنزيمات ( إنزيم السليلوز ) : أدى لزيادة امتصاص الصبغة الطبيعية وثباتها لكل الصفات التى تم قياسها قياسا بالعينات

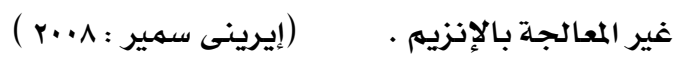

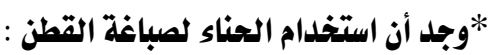

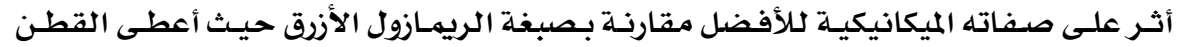

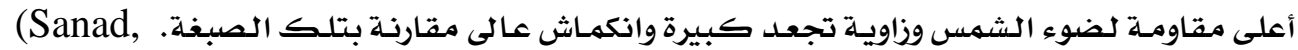
Suzan H., A.A.Ramadam:2004) *استخدام أشعة الألتراسونيك فى بحوث صباغة الألياف السليلوزية :

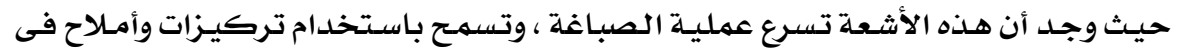

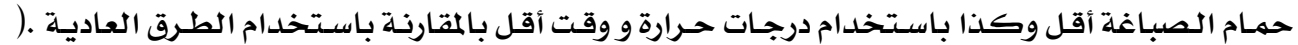

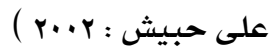

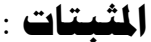

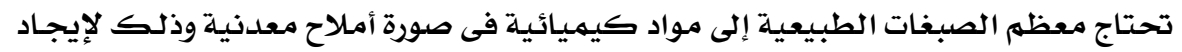
قوة جذب بين كل من النسيج والصبغة وبالتالى تحسين ثبات الألوان ، وهذه المواد تعرف بالمثبتات .

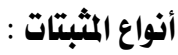

$$
\begin{aligned}
& \text { 1- أملاح معدنية أو مثبتات معدنية . }
\end{aligned}
$$

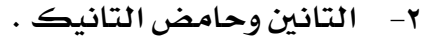

$$
\begin{aligned}
& \text { r- r- مثبتات زيتية }
\end{aligned}
$$

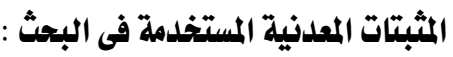

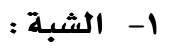

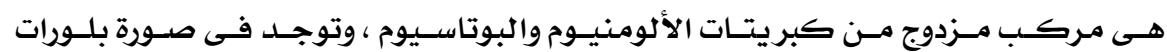

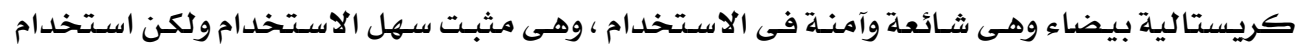

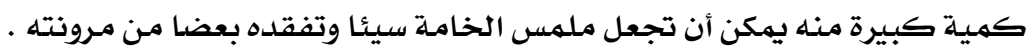

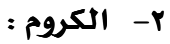

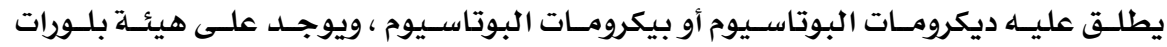

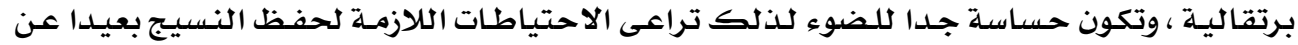

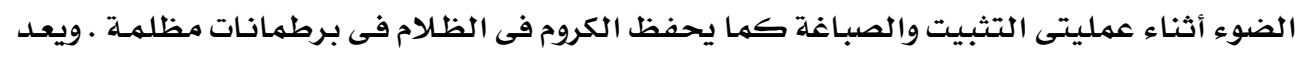




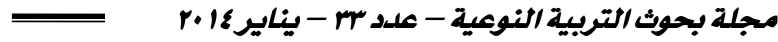

الكـروم مثبتا هامـا جــا وكذلك مرضى ومحبـب فى الاستخدلام كمثبـت حيث يعطى ألوانـا دافئسة

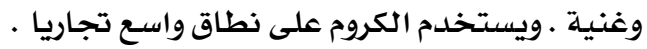

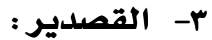

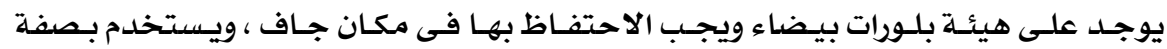

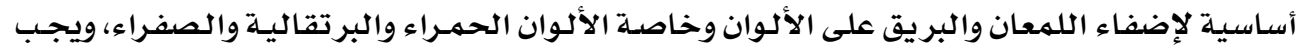

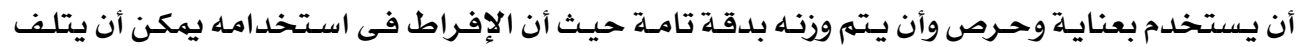
الخاملة ويجعلها خشنة الملمس هشة وسريعة التلف. طرق التثبيت :

$$
\begin{aligned}
& \text { 1- أبل عملية الصباغة . } \\
& \text { r- أثناء عملية الصباغة . }
\end{aligned}
$$

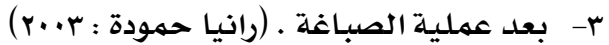

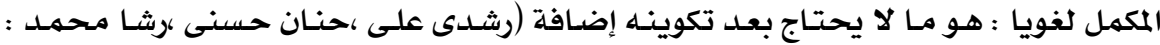

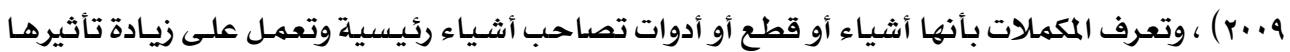

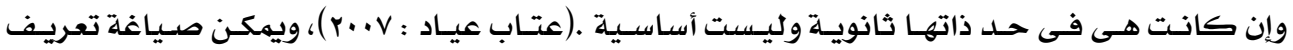

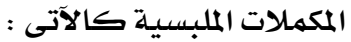

هى أشـياء أو قطـع أو أدوات تصـاحب الملابس تعمل على زيـادة تأثيرهـا مهـا يـؤدى إلى كمهال

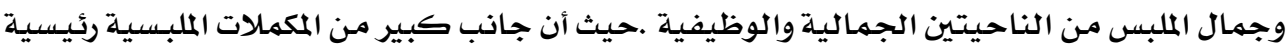

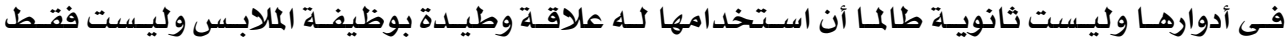

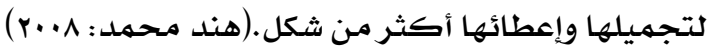
أهمية مكملات الملابس :

$$
\text { 1- تضيف لمظهر الشخص بريقا وجاذبيـة . }
$$

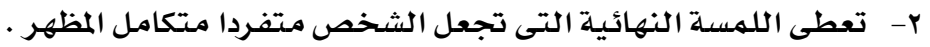

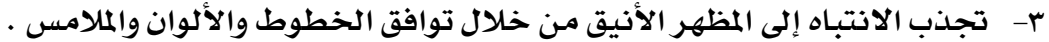

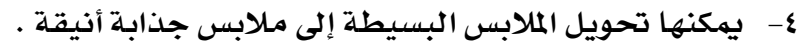

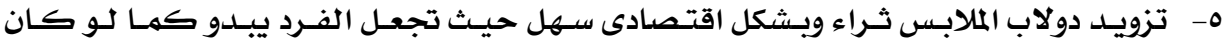

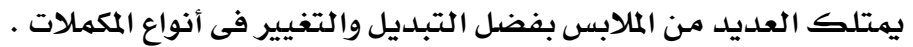

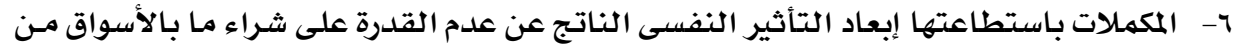
منتجات ملبسية

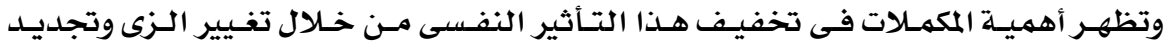

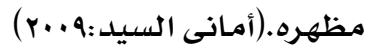




\section{ا- مكملات ثابتة أو متصلة (الكلف) :}

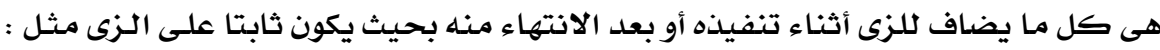

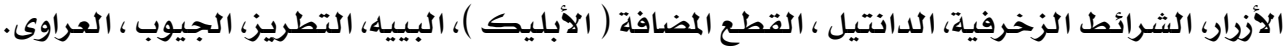

r- مكملات ملابس غير ثابته أو منفصلة ( الاكسسوار ) :

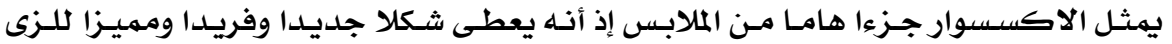

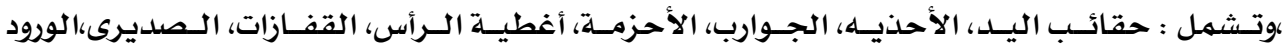

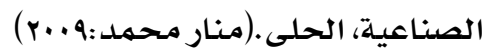

أغطية الرأس الصينة

وتشهمل القبعـات والبونيهـات والإيـشاريات ، وتعتـبر الإيشـاريـات مـن أكثـر المكمـلات المؤثرة

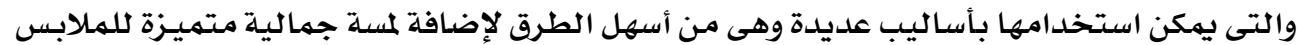

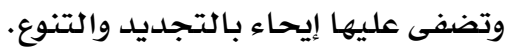

وينبغى مـراعاة أن الإيشارب يربط بين الألوان المتباينة فى الملابس ومكملاتها وله القدرة على لى

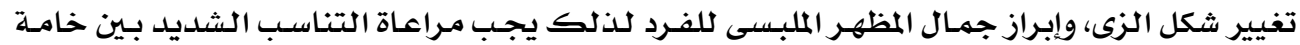

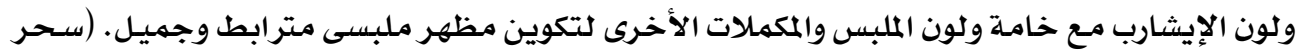

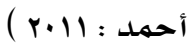

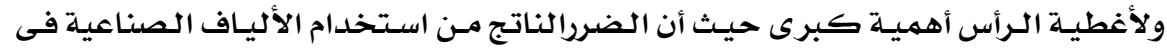

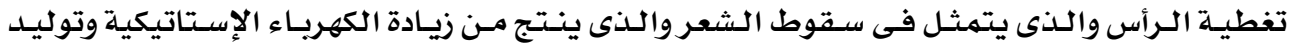

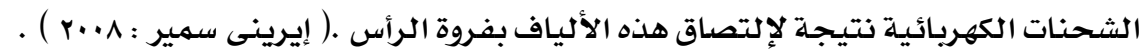

التجارب العملية والاختبارات المعملية :

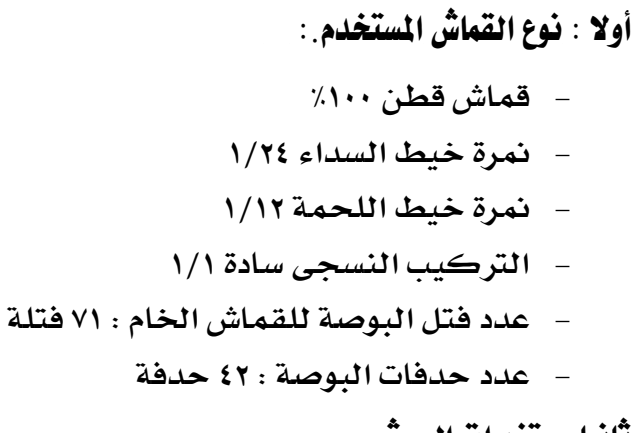

ثانيا : متفيرات البحث :

ا- نوع المثبت : الشبة Alum، الكروم Chrome، القصدير Tin

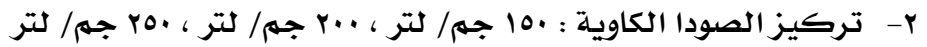

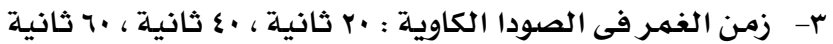




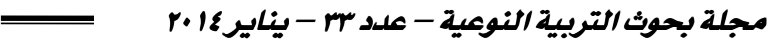

ع- درجة حرارة الصودا الكاوية : درجة حرارة الغرفة ، درجة حرارة هه درجة مئوية

ثالثا : عملية المرسرة ( التحرير ) :

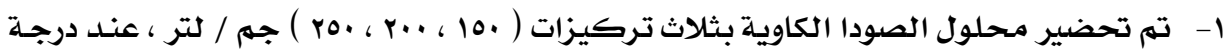

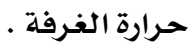

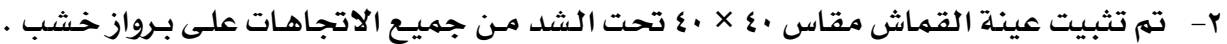

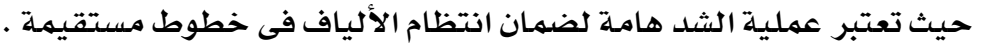

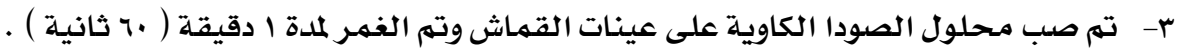

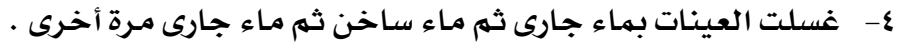

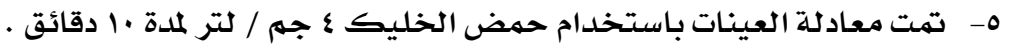

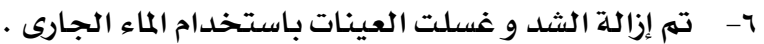

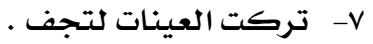

رابعا : نوع الصبفة الطبيعية :

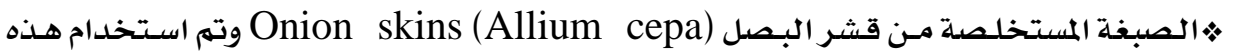

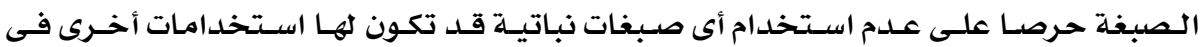

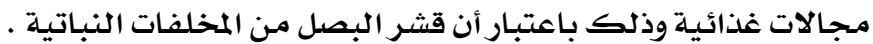

هُتركيز الصبغة : تم استخدام الصبغة بتركيز ع جم/ ..1 مل ماء

خامسا : المثبتات المستخدمة :

تم استخدام ثلاث أنواع من المثبتات المعدنية وهى :

ا- الشبة (KAL(SO4)2. 12H2O) Alum)

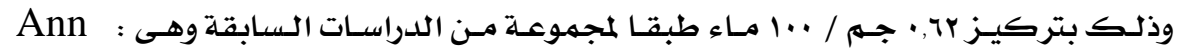

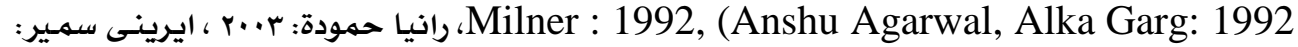

( r...

: ) Chrome (K2 Cr2 o7 الكروم

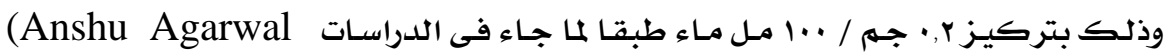

(r..r. : Alka Garg : 1992

r- القصدير Sncl2 .2H20) Tin)

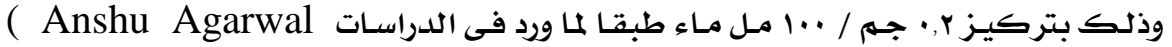

1992

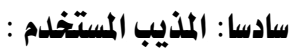

تم استخدام الماء كملذيب فى عمليتى استخلاص الصبغة ، الصباغة . 


$$
\begin{aligned}
& \text { سابعا : إجراsات الصباغة : }
\end{aligned}
$$

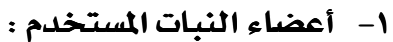

$$
\begin{aligned}
& \text { البصل وتم استخلاص الصبغة من قشر البصل . }
\end{aligned}
$$

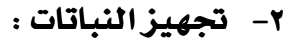

ا- تم تحضير قشور النبات الجافة التى سيستخلص منهها الصبغة .

r- تم تنقية القشور حيث تم التخلص مـن القشور غير السليمـة .

r- تم طحن القشور بقدر الإمكان حتى تتحول إلى قطع صغيرة للغاية .

ع- تم الاحتفاظ بها أوعيـة جافة ومغلقة لحين الاستخدام .

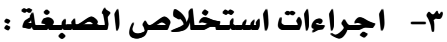

ا- تم تحضير كميـة الماء المطلوبـة تبعـا لوزن الخامسة المراد صسباغتها وذلك بنسبـة ( اجهم مسن

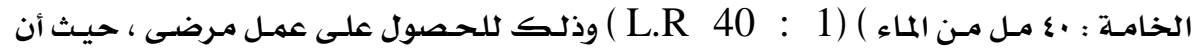
الإسـراف فى كميلة الماء يعد تبـذيرا فى حين أن المقدار غير الكافى مـن الماء قد يؤدى إلى تغلغـل

$$
\text { غير منتظظم وغير متتجانس · }
$$

r- ت تم تحضير الوزن الطلوب من الصبغة الجافة السـابق طحنها .

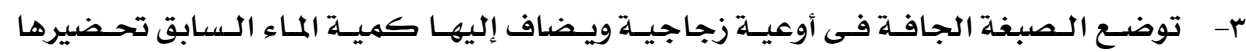

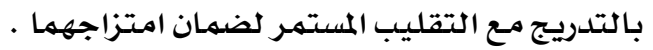
ع- تغطى الأوعية الزجاجية باستخدام غطاء محكمى أو باستخدام ورق الألومنيوم حتى لا تتبـخر أيسة كميلة من الماء.

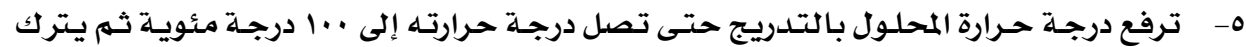
المحلول عند هذه الدرجة لمدة (1) سـاعة لإستخخلاص الكمية المناسبـة من الصبيغة . 7- بعد انتهاء زمن الإستخلاص ته نقل الأوعية الزجاجية بعيدا عن اللهب وتترك لتبرد .

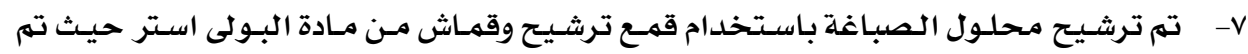

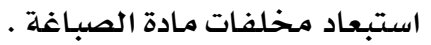

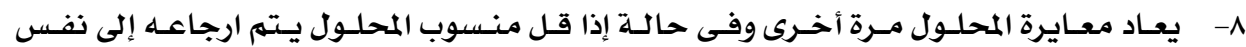

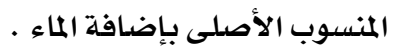
9- يعاد ترشيـح محلول الصبـاغة مـرة أخـرى للتخلص مـن أيـة شـوائب موجـودة وفى هـذه الحالـة

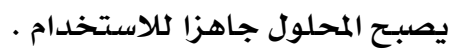
ع- مريقة المباغة :

ا- تم وزن وتحضير العينات التى سيتمر صبـاغتها حيث تزن العينة ( 9 جمر ) . ץ- تم تحضير حمام الصبـاغة الذى يحتوى على محلول الصبغـة حسب الكميـة المطلوبـة بنسبـة ا جم مـن الخامـة : · ع مل مـاء ، وبالتالى يحتوى حمام الصباغة للعينة الواحدة على ( • بس مـل ) من مححلول الصبـاغة لكل عينة تزن (و جمر ) . r- تمت عملية الصباغة باستخدام جهاز ( Launder-Ometer Standard Instrument ) . 


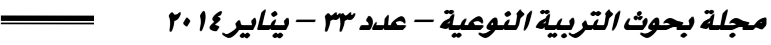

ع- يحتوى الجهاز على عدد خمس حوامل يثبت بها عدد مـن الأوعيـة محكمسة الغلق حيث يوضـع

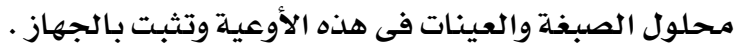

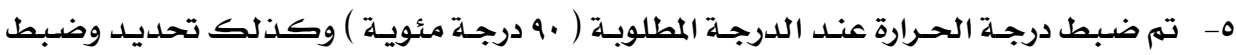

الزمن الذى ستستغرقه عملية الصباغة ( الساعة ) .

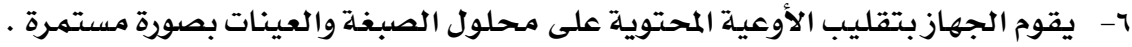

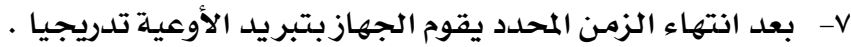

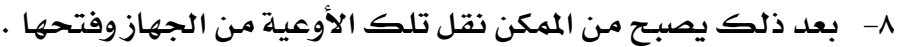

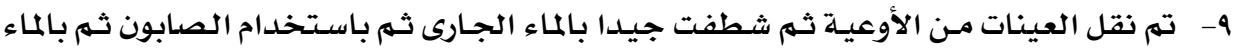

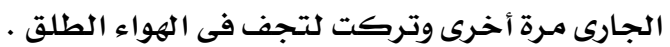

ثامنا : طريقة التثبيت :

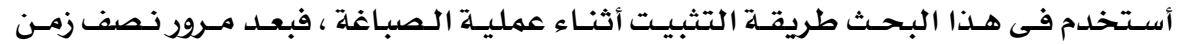

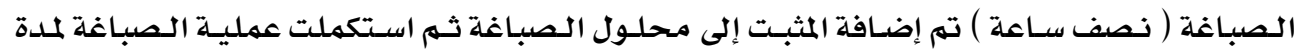

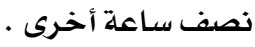

الطريقة :

1- - ت تم وزن المثبت المستخدم بدقة .

r- يذاب المثبت فى قليل من محلول الصبغة وذلك بعد مرور نصف زمن الصباغة .

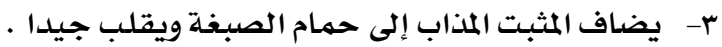

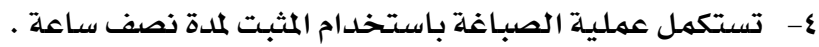

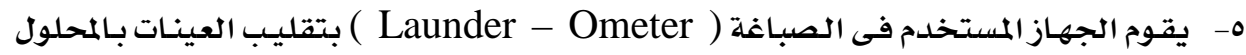

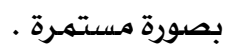

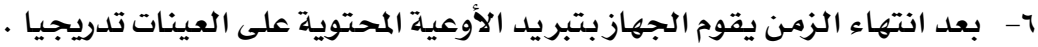

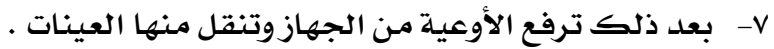

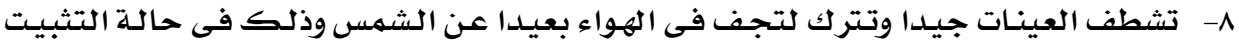

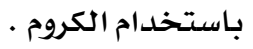

تاسعا : مراحل العمل :

المرحلة الأولى : دراسة تأثير نوع المثبت على الخواص الطبيعية والميكانيكية وكفاءة الصباغة للقماش

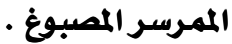

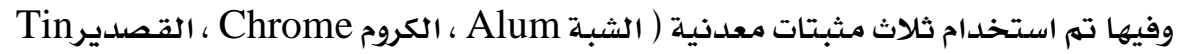

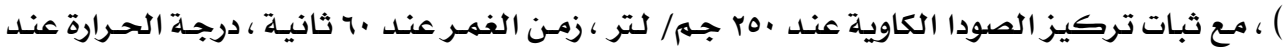

درجة حرارة الغرفة . 


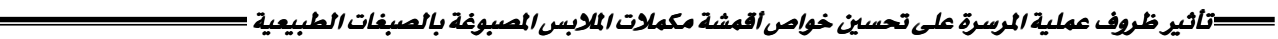

المرحلـة الثانيـة : دراسـة تأثير تركيز الـصودا الكاويـة فى عمليـة المرسـرة على الخـواص الطبيعيـة والميكانيكية وكفاءة الصباغة للقماش الممرسر المصبوغ •

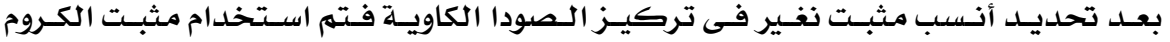

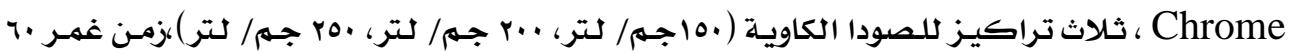
ثانية ، درجة حرارة عند درجة حرارة الغرفئة .

المرحلة الثالثة : دراسـة تأثير زمـن الغمـر فى الصودا الكاويـة على الخـواص الطبيعيـة والميكانيكيـة وكفاءة الصباغة للقماش الممرسر المصبوغ المرنه

بعد تحديد أنسب مثبت ، أنسب تركيز للصودا الكاويـة ندرس تأثير زمـن الغمـر في الصودا

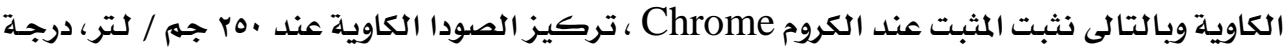

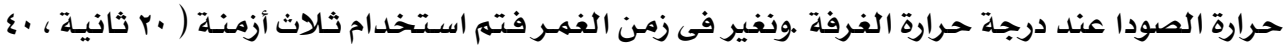

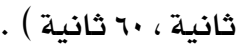

المرحلة الرابعة : دراسة تأثير درجة حرارة الصودا الكاوية على الخواص الطبيعية والميكانيكية وكفاءة

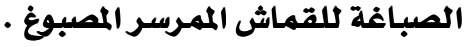

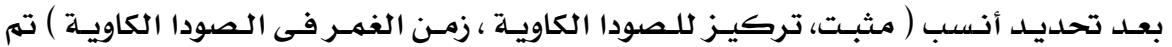

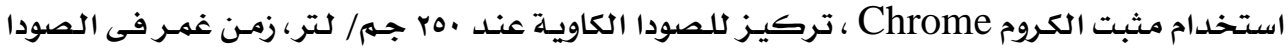

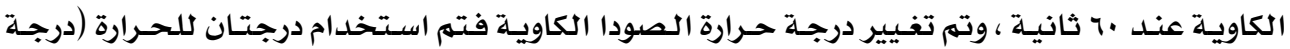

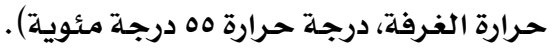

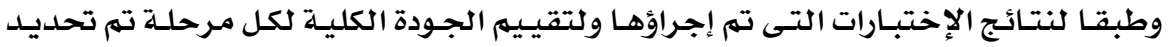

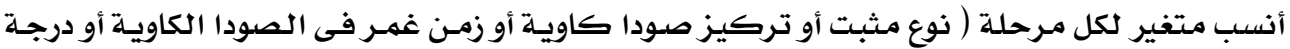

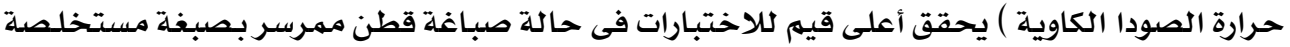

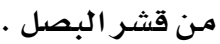
عاشرا: الاختبارات المعملية :

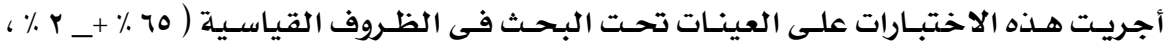

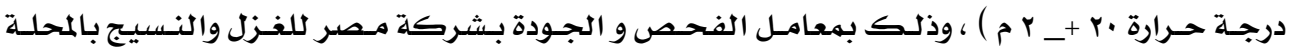

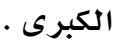
1- اختبار قوة الشد القاطع للقماث ( كجم ) .

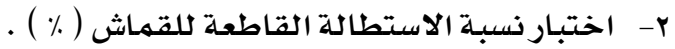
وقد تم إجراء اختبارات قوة الشد ونسبة الاستطالة طبقا للمواصفات القياسية المصرية رقم

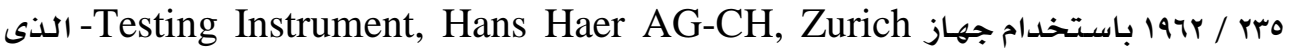

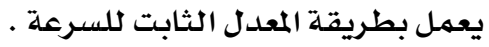


r- م/ اختبار قياس عمق اللون K/S :

Spectro Photometer,Data Colour International Model تم استخدام جهاز

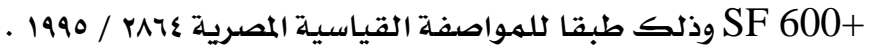
ع- اختبار ثبات اللون للغسيل :

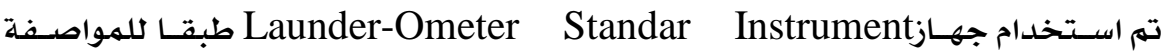

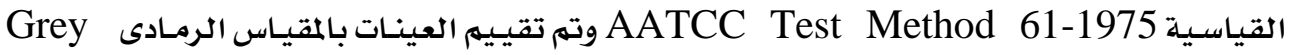
. Scale

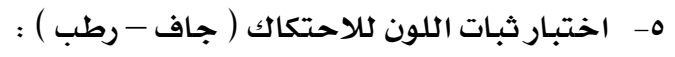

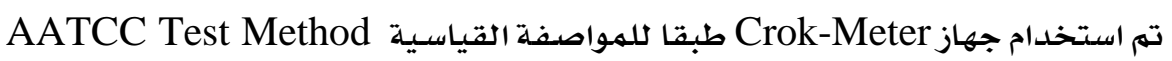

1977- 8 وتم تقييم مدى التغير فى لون العينات باستخدام المقياس الرمادى Grey Scale .

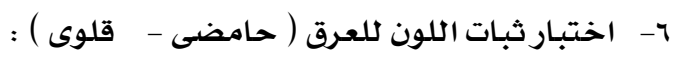

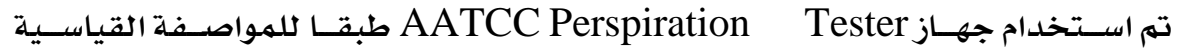

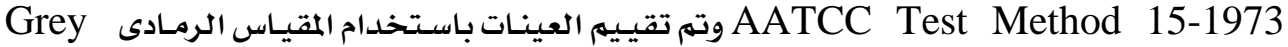

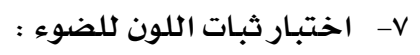

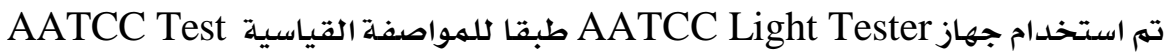

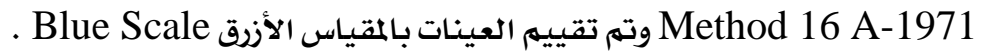

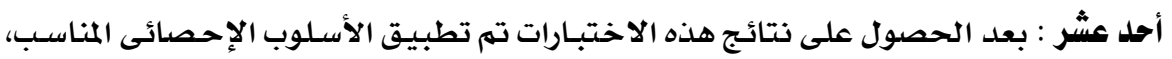

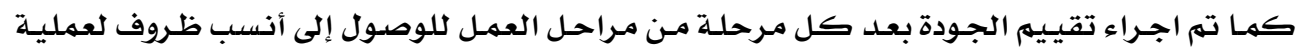

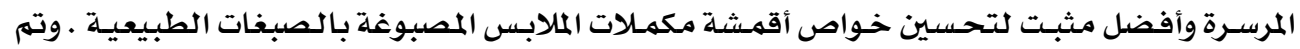

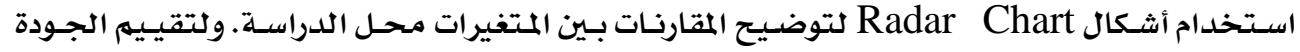

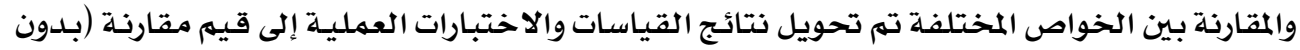

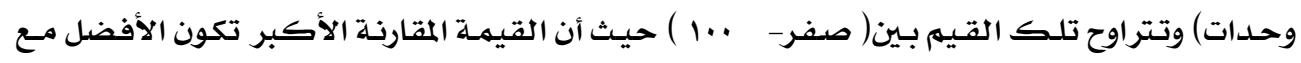

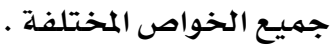

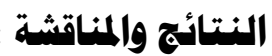

الفرض الأول : أن

توجد فروق ذات دلالة إحصائية بـين نوع المثبت والخـواص الطبيعيـة والميكانيكية وكفـاءة الصباغة للقماش الممرسر المصبوغ . 


\begin{tabular}{|c|c|c|c|c|c|}
\hline \multicolumn{6}{|c|}{ جدول ( 1 ) تحليل التباين لتأثير نوع المثبت على الخواص الطبيعية والميكانيكية للقماش الممرسر المصبوغ } \\
\hline الدلالة & قيمة ( ف) & 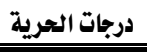 & متوسط المربعات & 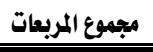 & \\
\hline \multicolumn{6}{|c|}{ ع/S ع عق اللون } \\
\hline \multirow{3}{*}{ 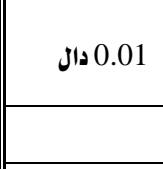 } & \multirow{2}{*}{40.579} & 5 & 27.326 & 136.630 & 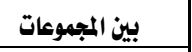 \\
\hline & & 12 & 0.673 & 8.081 & 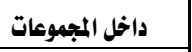 \\
\hline & & 17 & & 144.711 & 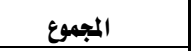 \\
\hline \multicolumn{6}{|c|}{ قوة الشد (كجم) سداء } \\
\hline \multirow{3}{*}{0.01} & \multirow{2}{*}{32.131} & 5 & 371.289 & 1856.444 & بين المجموعات \\
\hline & & 12 & 11.556 & 138.667 & داخل المجموعات \\
\hline & & 17 & & 1995.111 & المجموع \\
\hline \multicolumn{6}{|c|}{ لحمة } \\
\hline \multirow{3}{*}{0.010} & \multirow{2}{*}{28.722} & 5 & 110.100 & 550.500 & بين المجموعات \\
\hline & & 12 & 3.833 & 46.000 & داخل المجموعات \\
\hline & & 17 & & 596.500 & المجموع \\
\hline \multicolumn{6}{|c|}{ نسبة الاستطالة (\%) سداء } \\
\hline \multirow{3}{*}{0.010} & \multirow{2}{*}{7.499} & 5 & 76.653 & 383.265 & بين المجموعات \\
\hline & & 12 & 10.222 & 122.667 & داخل المجموعات \\
\hline & & 17 & & 505.932 & المجموع \\
\hline \multicolumn{6}{|c|}{ لحمة } \\
\hline \multirow{3}{*}{0.0100 دال } & \multirow{2}{*}{5.525} & 5 & 81.116 & 405.579 & بين المجموعات \\
\hline & & 12 & 14.681 & 176.167 & داخل المجموعات \\
\hline & & 17 & & 581.746 & المجموع \\
\hline
\end{tabular}

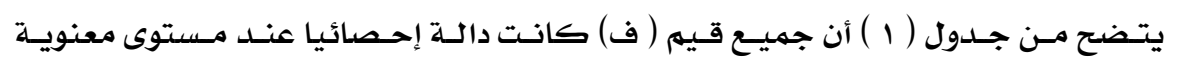

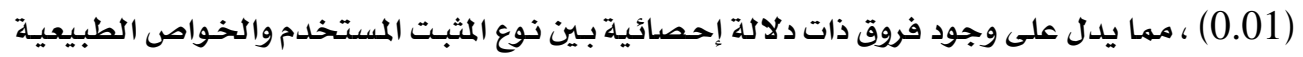

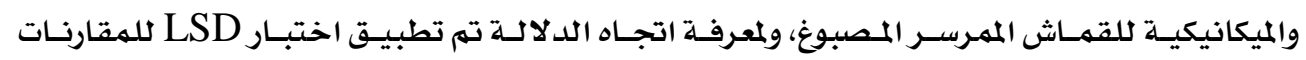

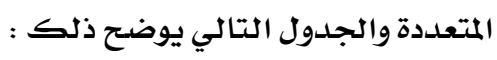




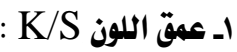

جدول ( r ) اختبـار LSD للمقارنات المتعددة لتأثير نوع المثبت على عمق اللون

\begin{tabular}{|c|c|c|c|c|c|c|c|}
\hline \multicolumn{3}{|c|}{ مصبوغ وممرسر } & \multicolumn{3}{|c|}{ مصبوغ بلدون مرسرة } & \multirow{3}{*}{\multicolumn{2}{|c|}{ عمق اللون }} \\
\hline \multirow{8}{*}{$\begin{array}{c}\text { Tin } \\
12.730= \\
\end{array}$} & Chrome & Alum & Tin & Chrome & Alum & & \\
\hline & $13.850=$ & $8.830=$ ? & $9.140=$ ? & $6.900=p$ & $6.500=$ & & \\
\hline & & & & & & Alum & \multirow{3}{*}{ مصبوغ } \\
\hline & & & & & -0.400 & Chrome & \\
\hline & & & & $* * 2.240$ & $* * 2.640$ & Tin & \\
\hline & & & -0.310 & $* * 1.930$ & $* * 2.330$ & Alum & \multirow{3}{*}{ ومبرغ } \\
\hline & & $* * 5.020$ & $* * 4.710$ & $* * 6.950$ & $* * 7.350$ & Chrome & \\
\hline & $* 1.120$ & $* * 3.900$ & $* * 3.590$ & $* * 5.830$ & $* * 6.230$ & Tin & \\
\hline
\end{tabular}

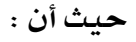

م متوسط النتائج ** معنوى عند مستوى ( 1 (.. ) * معنوى عند مستوى ( 0.. • ) - غير معنوى

$$
\text { يتضح من جدول (r) أن: }
$$

العينـات الممـرسـرة والمـصبوغة بـاستخدام مثبـت Chrome أعطت أعلى عمـق للـون ، بينهـا

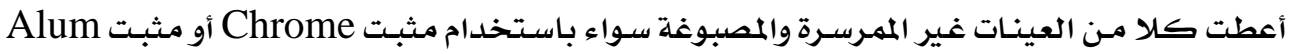

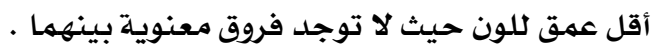
rـ قوة الشدل (كجم) :

أولا : قوة الشد فى اتجاه السداء :

جدول ( r ) اختبار LSD للمقارنات المتعددة لتأثير نوع المثبت على قوة الشد فى اتجاه السداء لهوه

\begin{tabular}{|c|c|c|c|c|c|c|c|}
\hline \multicolumn{3}{|c|}{ مصبوغ وممرسر } & \multicolumn{3}{|c|}{ مصبوغ بلدون مرسرة } & \multirow{2}{*}{\multicolumn{2}{|c|}{ سلداء س }} \\
\hline \multirow{8}{*}{$\begin{array}{c}\text { Tin } \\
71.000=\end{array}$} & Chrome & Alum & Tin & Chrome & Alum & & \\
\hline & $78.000=$ p & $73.000=p$ & $53.000=p$ & $58.000=$ & $56.000=p$ & & \\
\hline & & & & & & Alum & \multirow{3}{*}{ مصبوغ بلدون } \\
\hline & & & & & $* 2.000$ & Chrome & \\
\hline & & & & $* * 5.000$ & $* * 3.000$ & Tin & \\
\hline & & & $* * 20.000$ & $* * 15.000$ & $* * 17.000$ & Alum & \multirow{3}{*}{ مصبوغ وممرسر } \\
\hline & & $* * 5.000$ & $* * 25.000$ & $* * 20.000$ & $* * 22.000$ & Chrome & \\
\hline & $* * 7.000$ & $* 2.000$ & $* * 18.000$ & $* * 13.000$ & $* * 15.000$ & Tin & \\
\hline
\end{tabular}

يتضح من جدول (r) أن: 


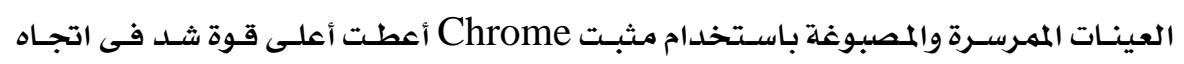

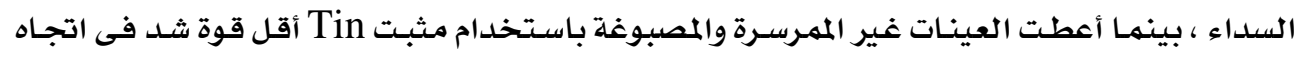

السسداء

ثانيا : قوة الشد فى اتجاه اللحمة :

جدول ( ع ) اختبار LSD للمقارنات المتعددة لتأثير نوع المثبت على قوة الشد في اتجاه اللحمة

\begin{tabular}{|c|c|c|c|c|c|c|c|}
\hline \multicolumn{3}{|c|}{ مصبوغ وممرسر } & \multicolumn{3}{|c|}{ مصبوغ بدون مرسرة } & \multirow{3}{*}{\multicolumn{2}{|c|}{ لحمة }} \\
\hline \multirow{8}{*}{$\begin{array}{c}\text { Tin } \\
60.000=\end{array}$} & Chrome & Alum & Tin & Chrome & Alum & & \\
\hline & $66.000=p$ & $62.000=p$ & $52.000=p$ & $54.000=p$ & $51.000=P$ & & \\
\hline & & & & & & Alum & \multirow{3}{*}{ مصبوغ بدون } \\
\hline & & & & & $* * 3.000$ & Chrome & \\
\hline & & & & $* 2.000$ & $* 1.000$ & Tin & \\
\hline & & & $* * 10.000$ & $* * 8.000$ & $* * 11.000$ & Alum & \multirow{3}{*}{ مصبوغ وممرسر | } \\
\hline & & $* * 4.000$ & $* * 14.000$ & $* * 12.000$ & $* * 15.000$ & Chrome & \\
\hline & $* * 6.000$ & $* 2.000$ & $* * 8.000$ & $* * 6.000$ & $* * 9.000$ & Tin & \\
\hline
\end{tabular}

يتضح من جدول (ع) أن:

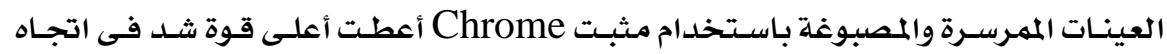

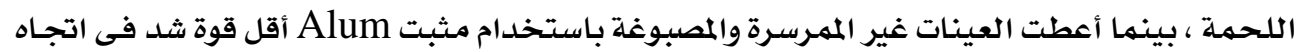

اللحمة .

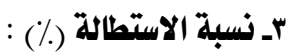

أولا : نسبة الاستطالة فى اتجاه السداء :

جدول ( ه ) اختبار LSD للمقارنات المتعددة لتأثير نوع المثبت على نسبة الاستطالة في اتجاه السداء

\begin{tabular}{|c|c|c|c|c|c|c|c|}
\hline \multicolumn{3}{|c|}{ مصبوغ وممرسر } & \multicolumn{3}{|c|}{ مصببو بلدون مرسرة } & \multirow{3}{*}{\multicolumn{2}{|c|}{ سلداs اء }} \\
\hline \multirow{8}{*}{$\begin{array}{c}\text { Tin } \\
17.500=\end{array}$} & Chrome & Alum & Tin & Chrome & Alum & & \\
\hline & $17.490=$ A & $16.000=$ & $14.960=\mathrm{A}$ & $16.500=A$ & $15.000=A$ & & \\
\hline & & & & & & Alum & \multirow{3}{*}{ مصبوغ بدون } \\
\hline & & & & & $* * 1.500$ & Chrome & \\
\hline & & & & $* * 1.540$ & -0.040 & Tin & \\
\hline & & & $* 1.040$ & $* 0.500$ & $* 1.000$ & Alum & \multirow{3}{*}{ صببوغ وممرسر } \\
\hline & & $* * 1.490$ & $* * 2.530$ & $* 0.990$ & $* * 2.490$ & Chrome & \\
\hline & -0.010 & $* * 1.500$ & $* * 2.540$ & $* 1.000$ & $* * 2.500$ & Tin & \\
\hline
\end{tabular}




$$
\text { يتضح من جدول (0) أن : }
$$

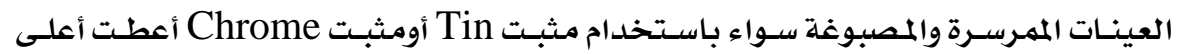

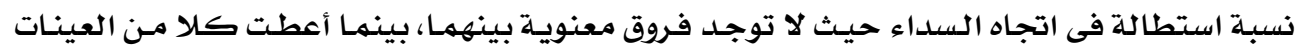

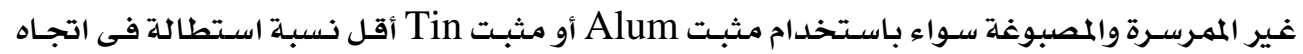

السداء حيث لا توجد فروق معنوية بينهما. ثانيا: نسبـة الاستطانة فى اتجاه اللحمة : جدول ( ا ) اختبـار LSD للمقارنات المتعددة لتأثير نوع المثبت على نسبـة الاستطالة في اتجاه اللحمة

\begin{tabular}{|c|c|c|c|c|c|c|c|}
\hline \multicolumn{3}{|c|}{ مصبوغ وممرسر } & \multicolumn{3}{|c|}{ مصبوغ بلدون مرسرة } & \multirow{3}{*}{\multicolumn{2}{|c|}{ لحمة }} \\
\hline Tin & Chrome & Alum & Tin & Chrome & Alum & & \\
\hline \multirow[t]{7}{*}{$17.490=\hat{~}$} & $19.000=p$ & $18.000=$ & $17.000=$ P & $17.480=\hat{R}$ & $17.500=$ & & \\
\hline & & & & & & Alum & \multirow{3}{*}{ مصبوغ بلدون } \\
\hline & & & & & -0.020 & Chrome & \\
\hline & & & & $* 0.480$ & $* 0.500$ & Tin & \\
\hline & & & $* 1.000$ & $* 0.520$ & $* 0.500$ & Alum & \multirow{3}{*}{ صببوغ وممرسر } \\
\hline & & $* 1.000$ & $* * 2.000$ & $* * 1.520$ & $* * 1.500$ & Chrome & \\
\hline & $* * 1.510$ & $* 0.510$ & $* 0.490$ & -0.010 & -0.010 & Tin & \\
\hline
\end{tabular}

$$
\text { يتضح من جدول (؟) أن: }
$$

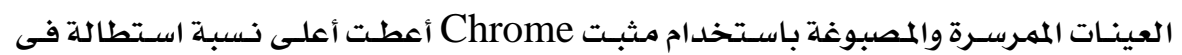

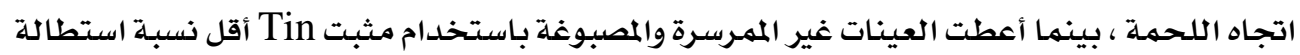
فى اتجاه اللحمة .

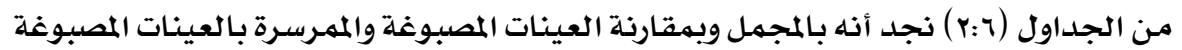

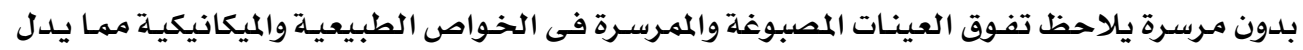

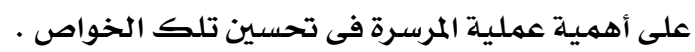




\begin{tabular}{|c|c|c|c|c|c|}
\hline \multicolumn{6}{|c|}{ جدول ( v ) تحليل التباين لتأثير نوع المثبت على خواص الثبات للقماش الممرسر المصبوغ } \\
\hline الدلالة & قيمة (ف) & درجات الحرية & متوسط المربعات & مجموع المربعات & \\
\hline \multicolumn{6}{|c|}{ الثبات للفسيل } \\
\hline \multirow{3}{*}{ ا 0.01 دال } & \multirow{2}{*}{8.365} & 5 & 5.593 & 27.966 & بين المجموعات \\
\hline & & 12 & 0.669 & 8.023 & داخل المجموعات \\
\hline & & 17 & & 35.989 & المجهوع \\
\hline \multicolumn{6}{|c|}{ الثبات للاحتكاك جاف } \\
\hline \multirow{3}{*}{ ا 0.01 دال } & \multirow{3}{*}{6.633} & 5 & 3.850 & 19.249 & بين المجموعات \\
\hline & & 12 & 0.580 & 6.965 & داخل المجموعات \\
\hline & & 17 & & 26.214 & المجموع \\
\hline \multicolumn{6}{|c|}{ رطب } \\
\hline \multirow{3}{*}{ ا 0.01 دال } & \multirow{3}{*}{5.629} & 5 & 5.453 & 27.266 & بين المجموعات \\
\hline & & 12 & 0.969 & 11.624 & داخل المجموعات \\
\hline & & 17 & & 38.890 & المجموع \\
\hline \multicolumn{6}{|c|}{ 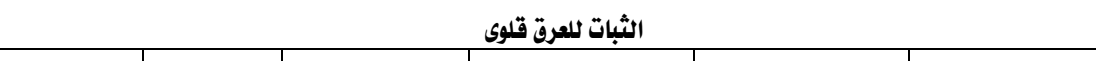 } \\
\hline \multirow{3}{*}{ ا 0.01 دال } & \multirow{3}{*}{5.024} & 5 & 5.303 & 26.515 & بين المجموعات \\
\hline & & 12 & 1.056 & 12.667 & داخل المجموعات \\
\hline & & 17 & & 39.182 & المجموع \\
\hline \multicolumn{6}{|c|}{ حامضى } \\
\hline \multirow{3}{*}{ ا 0.01 دال } & \multirow{3}{*}{6.985} & 5 & 4.498 & 22.492 & بين المجموعات \\
\hline & & 12 & 0.644 & 7.728 & 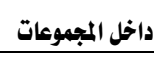 \\
\hline & & 17 & & 30.220 & المجموع \\
\hline \multicolumn{6}{|c|}{ الثبات للضوs } \\
\hline \multirow{3}{*}{ ا 0.01 دال } & \multirow{3}{*}{6.358} & 5 & 10.020 & 50.100 & بين المجموعات \\
\hline & & 12 & 1.576 & 18.912 & 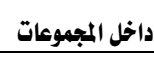 \\
\hline & & 17 & & 69.012 & الججموع \\
\hline
\end{tabular}

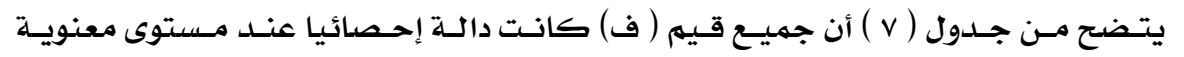

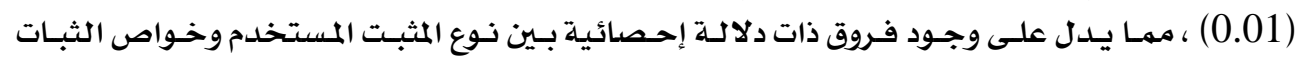

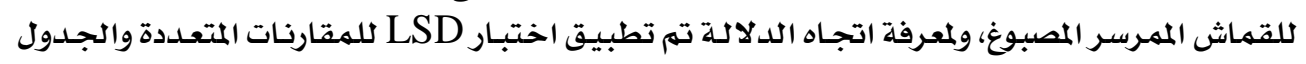

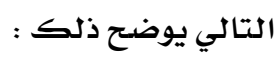




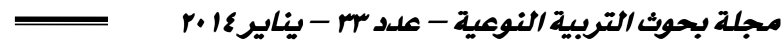

ا_الثبات للفسيل :

جدول ( ^ ) اختبار LSD للمقارنات المتعددة لتأثير نوع المثبت على الثبات للغسيل

\begin{tabular}{|c|c|c|c|c|c|c|c|}
\hline \multicolumn{3}{|c|}{ مصببوغ وممرسر } & \multicolumn{3}{|c|}{ مصبوغ بلدون مرسرة } & \multirow{2}{*}{\multicolumn{2}{|c|}{ الثبات للفسيل }} \\
\hline \multirow{8}{*}{$\begin{array}{c}\text { Tin } \\
2.000=\text { P }\end{array}$} & Chrome & Alum & Tin & Chrome & Alum & & \\
\hline & $4.000=p$ & $1.440=$ & $1.100=$ & $3.880=$ p & $1.000=$ & & \\
\hline & & & & & & Alum & \multirow{3}{*}{ مصبوغ بدون } \\
\hline & & & & & $* * 2.880$ & Chrome & \\
\hline & & & & $* * 2.780$ & -0.100 & Tin & \\
\hline & & & -0.340 & $* * 2.440$ & $* 0.440$ & Alum & \multirow{3}{*}{ مصبوغ وممرسر } \\
\hline & & $* * 2.560$ & $* * 2.900$ & -0.120 & $* * 3.000$ & Chrome & \\
\hline & $* * 2.000$ & $* 0.560$ & $* * 0.900$ & $* * 1.880$ & $* * 1.000$ & Tin & \\
\hline
\end{tabular}

يتضح من جدول (^) أن :

كلا مسن العينـات الممـرسـرة والمصبوغة باستخدام مثبـت Chrome والعينـات غير الممرسـرة

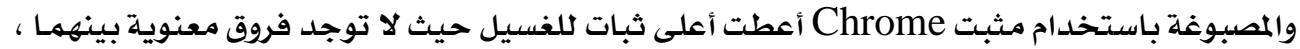

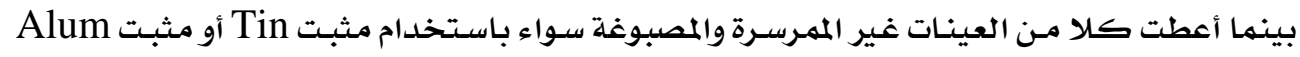

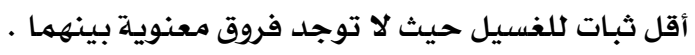

r.الثبات للاحتكاك :

أولا : الثبات لاحتكاك ( الجاف ) :

جدول ( ه ) اختبار LSD للمقارنات المتعددة لتأثير نوع المثبت على الثبات للاحتكاك (الجاف )

\begin{tabular}{|c|c|c|c|c|c|c|c|}
\hline \multicolumn{3}{|c|}{ مصبوغ وممرسر } & \multicolumn{3}{|c|}{ مصبوغ بلدون مرسرة } & \multirow{3}{*}{\multicolumn{2}{|c|}{ جاف }} \\
\hline \multirow{8}{*}{$\begin{array}{c}\text { Tin } \\
3.140=\mathrm{P} \\
\end{array}$} & Chrome & Alum & Tin & Chrome & Alum & & \\
\hline & $3.910=\hat{p}$ & $3.110=A$ & $3.000=p$ & $3.850=p$ & $2.000=\beta$ & & \\
\hline & & & & & & Alum & \multirow{3}{*}{ مصبوغ بلدون } \\
\hline & & & & & $* * 1.850$ & Chrome & \\
\hline & & & & $* * 0.850$ & $* * 1.000$ & Tin & \\
\hline & & & -0.110 & $* 0.740$ & $* * 1.110$ & Alum & \multirow{3}{*}{ مصبوغ وممرسر } \\
\hline & & $* * 0.800$ & $* * 0.910$ & -0.060 & $* * 1.910$ & Chrome & \\
\hline & $* 0.770$ & -0.030 & -0.140 & $* 0.710$ & $* * 1.140$ & Tin & \\
\hline
\end{tabular}

يتضح من جدول (q) أن: 


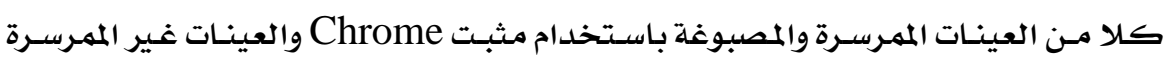

والمصبوغة باستخدام مثبت Chromeأعطت أعلى ثبات للاحتكاك حيث لا توجد فروق معنوية بينهما

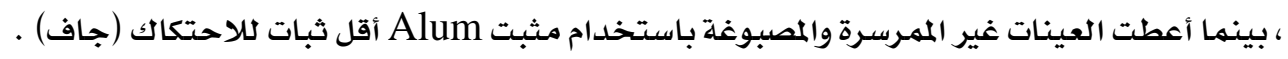
ثانيا : الثبات للاحتكاك ( الرطب ) :

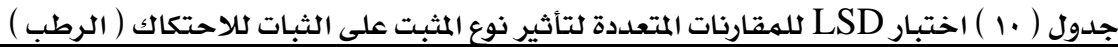

\begin{tabular}{|c|c|c|c|c|c|c|c|}
\hline \multicolumn{3}{|c|}{ مصبوغ وممرسر } & \multicolumn{3}{|c|}{ مصبوغ بلدون مرسرة } & \multirow{3}{*}{\multicolumn{2}{|c|}{ رطب }} \\
\hline \multirow{8}{*}{$\begin{array}{c}\text { Tin } \\
4.000=p\end{array}$} & Chrome & Alum & Tin & Chrome & Alum & & \\
\hline & $3.990=$ & $3.980=$ & $1.950=p$ & $3.320=p$ & $3.330=p$ & & \\
\hline & & & & & & Alum & \multirow{3}{*}{ مصبوغ بلدون } \\
\hline & & & & & -0.010 & Chrome & \\
\hline & & & & $* * 1.370$ & $* * 1.380$ & Tin & \\
\hline & & & $* * 2.030$ & $* 0.660$ & $* 0.650$ & Alum & \multirow{3}{*}{ مصبوغ وممرسر } \\
\hline & & -0.010 & $* * 2.040$ & $* 0.670$ & $* 0.660$ & Chrome & \\
\hline & -0.010 & -0.020 & $* * 2.050$ & $* 0.680$ & $* 0.670$ & Tin & \\
\hline
\end{tabular}

يتضح من جدول (. ) أن:

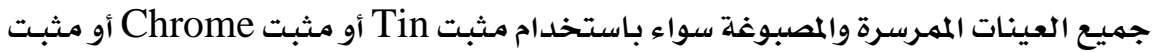

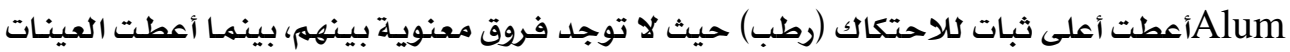

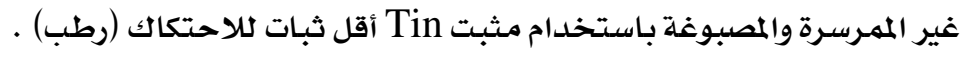

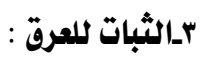

أولا : الثبات للعرق ( قلوى ) :

جدول ( 11 ) اختبار LSD للمقارنات المتعددة لتأثير نوع المثبت على الثبات للعرق (قلوى)

\begin{tabular}{|c|c|c|c|c|c|c|c|}
\hline \multicolumn{3}{|c|}{ مصبوغ وممرسر } & \multicolumn{3}{|c|}{ مصببوغ بلدون مرسرة } & \multirow{3}{*}{\multicolumn{2}{|c|}{ قلوى }} \\
\hline \multirow{8}{*}{$\begin{array}{c}\text { Tin } \\
3.970=\end{array}$} & Chrome & Alum & Tin & Chrome & Alum & & \\
\hline & $3.980=$ & $3.990=$ & $3.000=p$ & $3.960=R$ & $3.210=p$ & & \\
\hline & & & & & & Alum & \multirow{3}{*}{ ملدون مبرغ } \\
\hline & & & & & $* 0.750$ & Chrome & \\
\hline & & & & $* * 0.960$ & -0.210 & Tin & \\
\hline & & & $* * 0.990$ & -0.030 & $* 0.780$ & Alum & \multirow{3}{*}{ وممرسر } \\
\hline & & -0.010 & $* * 0.980$ & $-\cdot \cdot r \cdot$ & $* 0.770$ & Chrome & \\
\hline & -0.010 & -0.020 & $* * 0.970$ & -0.010 & $* 0.760$ & Tin & \\
\hline
\end{tabular}




$$
\text { يتضح من جدول (11) : }
$$

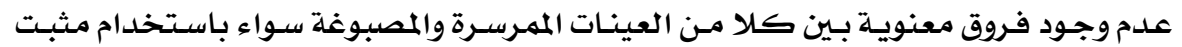

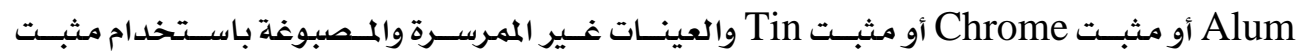

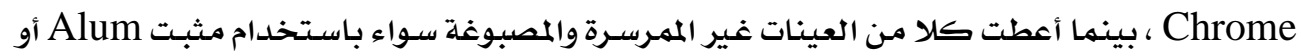

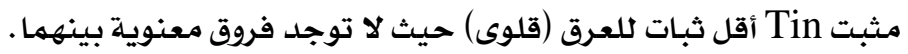
ثانيا : الثبات للعرق (حامضى) :

\begin{tabular}{|c|c|c|c|c|c|c|c|}
\hline \multicolumn{3}{|c|}{ مصبوغ وممرسر } & \multicolumn{3}{|c|}{ مصببوغ بلدون مرسرة } & \multirow{3}{*}{\multicolumn{2}{|c|}{ حامضى }} \\
\hline Tin & Chrome & Alum & Tin & Chrome & Alum & & \\
\hline \multirow[t]{7}{*}{$3.460=$ P } & $4.000=R$ & $3.120=\hat{~}$ & $3.000=p$ & $3.480=p$ & $2.610=p$ & & \\
\hline & & & & & & Alum & \multirow{3}{*}{ مصبوغ بلدون } \\
\hline & & & & & $* * 0.870$ & Chrome & \\
\hline & & & & $* 0.480$ & -0.390 & Tin & \\
\hline & & & -0.120 & -0.360 & $* 0.510$ & Alum & \multirow{3}{*}{ مصبوغ وممرسر } \\
\hline & & $* * 0.880$ & $* * 1.000$ & $* 0.520$ & $* * 1.390$ & Chrome & \\
\hline & $* 0.540$ & -0.340 & $* 0.460$ & -0.020 & $* * 0.850$ & Tin & \\
\hline
\end{tabular}

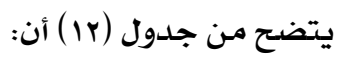

العينات الممـرسرة والمصبوغة باستخدام مثبت Chrome أعطت أعلى ثبات للعرق (حامضى)

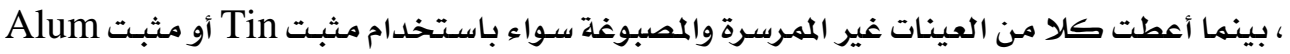

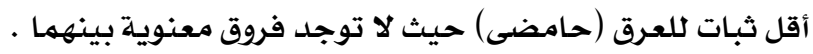

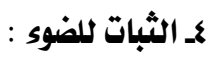

\begin{tabular}{|c|c|c|c|c|c|c|c|}
\hline \multicolumn{3}{|c|}{ مصبوغ وممرسر } & \multicolumn{3}{|c|}{ مصبوغ بلدون مرسرة } & \multirow{3}{*}{\multicolumn{2}{|c|}{ الثبات للضوs }} \\
\hline \multirow{8}{*}{$\begin{array}{c}\text { Tin } \\
6.990=\end{array}$} & Chrome & Alum & Tin & Chrome & Alum & & \\
\hline & $6.950=\boldsymbol{p}$ & $6.100=A$ & $6.000=p$ & $5.970=A$ & $5.220=A$ & & \\
\hline & & & & & & Alum & \multirow{3}{*}{ مصبوغ بلدون } \\
\hline & & & & & $* 0.750$ & Chrome & \\
\hline & & & & -0.030 & $* 0.780$ & Tin & \\
\hline & & & -0.100 & -0.130 & $* * 0.880$ & Alum & \multirow{3}{*}{ مصبوغ وممرسر } \\
\hline & & $* * 0.850$ & $* * 0.950$ & $* * 0.980$ & $* * 1.730$ & Chrome & \\
\hline & -0.040 & $\pm * 0.890$ & $* * 0.990$ & $\$ * 1.020$ & $* * 1.770$ & Tin & \\
\hline
\end{tabular}

جدول ( سا ) اختبار LSD للمقارنات المتعددة لتأثير نوع المثبت على الثبات للضوء 


$$
\text { يتضح من جدول (rا) أن : }
$$

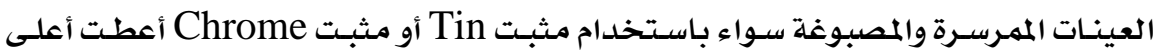

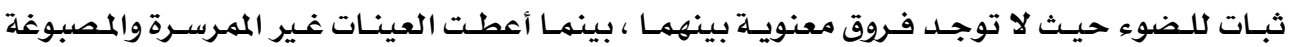
باستخدام مثبت Alum أقل ثبات للضوء ** تقييم الجودة الكلية لتأثير نوع المثبت على الخواص الطبيعية والميكانيكية وكفاءة الصباغة للقماش المثرسـر المصبوغ: جدول (ع ا) تقييم الجودة الكلية لتأثير نوع المثبت على الخواص الطبيعية والميكانيكية وكفاءة الصباغة للقماث المهرسر المصبوغ

\begin{tabular}{|c|c|c|c|c|c|c|c|c|c|c|c|c|c|c|}
\hline \multirow[t]{2}{*}{ الترتيب } & \multirow{2}{*}{ الجتييه } & \multirow{2}{*}{ للضوك الثبات } & \multicolumn{2}{|c|}{ الثبات للعرق \% } & \multicolumn{2}{|c|}{ الثبات للإحتكاك } & \multirow{2}{*}{ للفسيل الثبات } & \multicolumn{2}{|c|}{ نسبة الاستطالة \% } & \multicolumn{2}{|c|}{ قوة الشد ٪\% } & \multirow{2}{*}{ عمى اللون } & \multirow[t]{2}{*}{ الاختبار } & \multirow[t]{2}{*}{ العينة } \\
\hline & & & حهضي & ق ق قلوي & رطب & جاف & & اللحمة & السداء & اللحمة & السداs & & & \\
\hline 6 & 661.93 & 68.75 & 50.00 & 70.00 & 70.00 & 40.00 & 20.00 & 87.50 & 75.00 & 63.75 & 70.00 & 46.93 & Alum & مصبوغ \\
\hline 3 & 794.82 & 75.00 & 70.00 & 80.00 & 70.00 & 70.00 & 70.00 & 87.50 & 82.50 & 67.50 & 72.50 & 49.82 & Chrom & \multirow{2}{*}{ مرسرة } \\
\hline 5 & 662.24 & 75.00 & 60.00 & 60.00 & 30.00 & 60.00 & 20.00 & 85.00 & 75.00 & 65.00 & 66.25 & 65.99 & Tin & \\
\hline 4 & 787.50 & 75.00 & 60.00 & 80.00 & 80.00 & 60.00 & 30.00 & 90.00 & 80.00 & 77.50 & 91.25 & 63.75 & Alum & \multirow{3}{*}{ ومبرغ } \\
\hline 1 & 933.75 & 81.25 & 80.00 & 80.00 & 80.00 & 70.00 & 80.00 & 95.00 & 87.50 & 82.50 & 97.50 & 100.00 & Chrom & \\
\hline 2 & 841.91 & 81.25 & 70.00 & 80.00 & 80.00 & 60.00 & 40.00 & 87.50 & 87.50 & 75.00 & 88.75 & 91.91 & Tin & \\
\hline
\end{tabular}

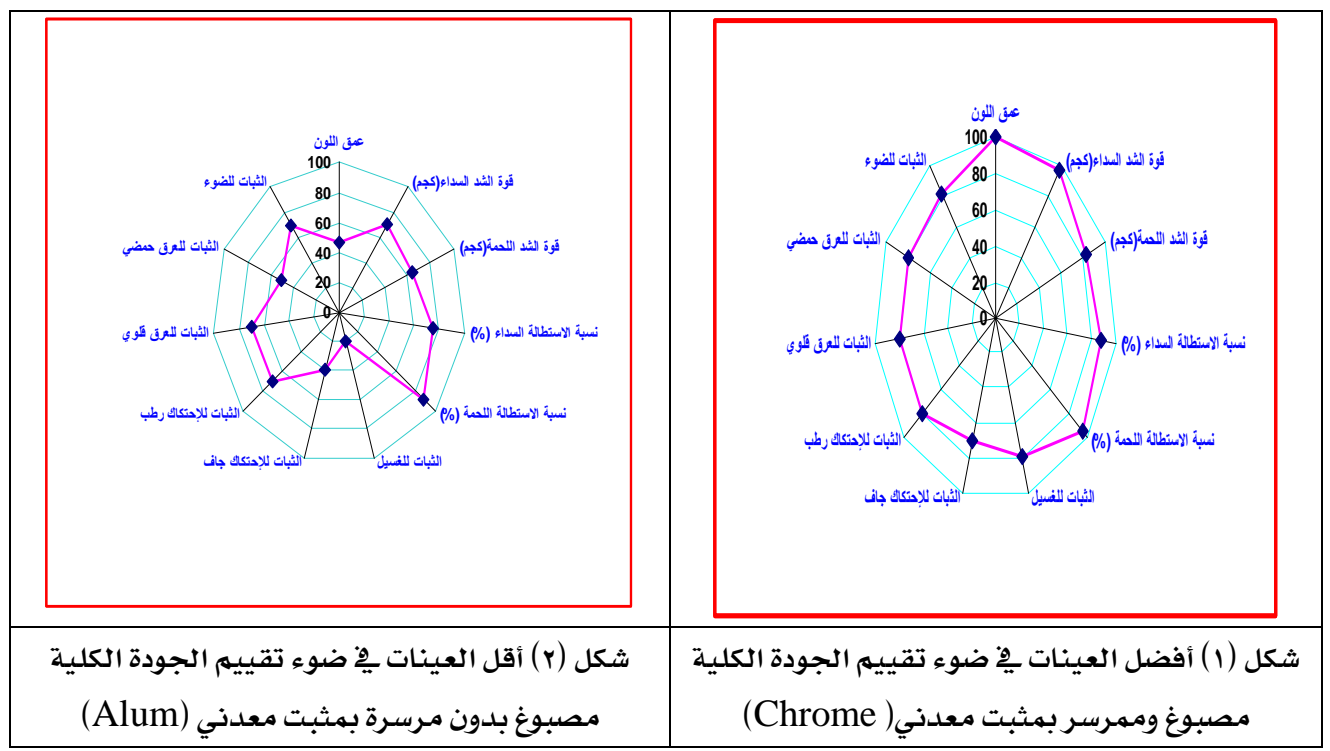




\section{مجلة بحوث التربية النوعية - عدد بr - بيناير}

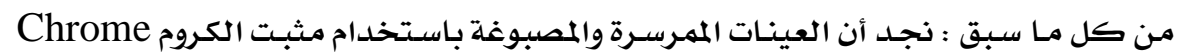

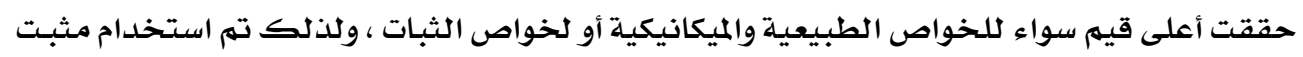

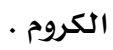
الفرض الثاني :

توجد فروق ذات دلالة إحصائية بين تركيز الصودا الكاويـة فى عمليـة المرسـرة والخـواص

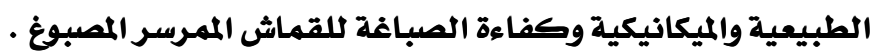

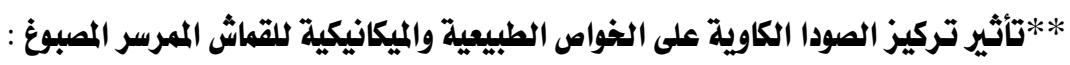
جدول (10)

\begin{tabular}{|c|c|c|c|c|c|}
\hline الدلالة & قيمة (ف) & درجات الحرية & متوسط المربعات & مجموع المربعات & \\
\hline \multicolumn{6}{|c|}{ ع/S عمق اللون } \\
\hline \multirow{2}{*}{0.010} & \multirow{2}{*}{29.824} & 3 & 38.797 & 116.390 & بين المجموعات \\
\hline & & 8 & 1.301 & 10.407 & داخل المجموعات \\
\hline & & 11 & & 126.797 & المجموع \\
\hline \multicolumn{6}{|c|}{ قوة الشد (كجم) سلداء } \\
\hline \multirow{3}{*}{0.010} & \multirow{2}{*}{15.648} & 6 & 120.714 & 724.286 & بين المجموعات \\
\hline & & 14 & 7.714 & 108.000 & داخل المجموعات \\
\hline & & 20 & & 832.286 & المجموع \\
\hline \multicolumn{6}{|c|}{ لحمة } \\
\hline \multirow{3}{*}{0.010} & \multirow{2}{*}{9.591} & 6 & 54.804 & 328.826 & بين المجموعات \\
\hline & & 14 & 5.714 & 80.000 & داخل المجموعات \\
\hline & & 20 & & 408.826 & المجموع \\
\hline \multicolumn{6}{|c|}{ نسبة الإستطالة (٪) سلداء } \\
\hline \multirow{3}{*}{0.010} & \multirow{2}{*}{5.991} & 6 & 60.260 & 361.561 & بين المجموعات \\
\hline & & 14 & 10.059 & 140.827 & داخل المجموعات \\
\hline & & 20 & & 502.388 & المجموع \\
\hline \multicolumn{6}{|c|}{ لحمة } \\
\hline \multirow{3}{*}{0.010} & \multirow{2}{*}{9.107} & 6 & 81.100 & 486.598 & بين المجهوعات \\
\hline & & 14 & 8.905 & 124.667 & داخل المجموعات \\
\hline & & 20 & & 611.265 & المجموع \\
\hline
\end{tabular}

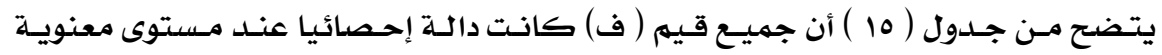

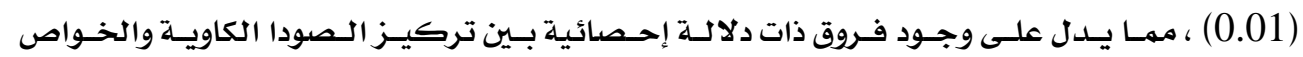

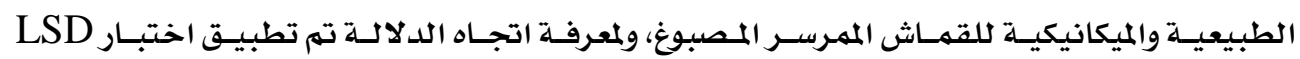

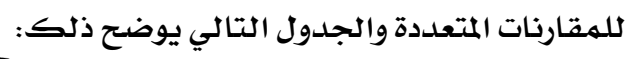


جدول ( 17 ) اختبار LSD للمقارنات المتعددة لتأثير تركيز الصودا الكاوية على عمق اللون

\begin{tabular}{|c|c|c|c|c|c|}
\hline \multicolumn{3}{|c|}{ مصبوغ وممرسر } & \multirow{2}{*}{$\begin{array}{c}\text { مصبوغ بلدون مرسرة } \\
\text { (صفر صودا) = } 6.900 \\
\text { مبرة }\end{array}$} & \multirow{2}{*}{\multicolumn{2}{|c|}{ ع/S عمق اللون }} \\
\hline صودا ro. & صودا •. Pو r & صودا •10 & & & \\
\hline & & & & فر صودا) & مصبوغ بدون م \\
\hline & & & $* 0.800$ & صودا •10 & \\
\hline & & $* * 3.000$ & $* * 2.200$ & صودا .. P & مصبوغ وممرسر \\
\hline & $* * 4.700$ & $* * 7.700$ & **6.900 & صودا • ص ro & \\
\hline
\end{tabular}

يتضح من جدول (17) :

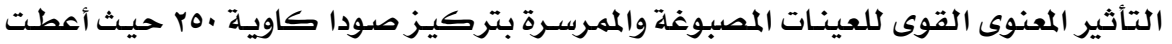

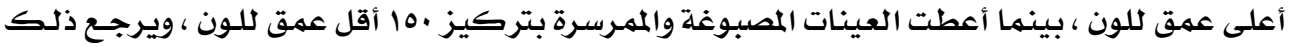

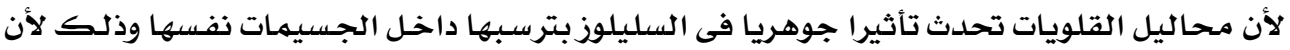

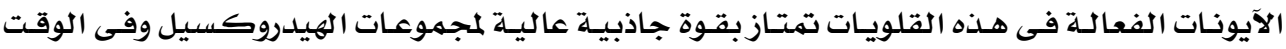

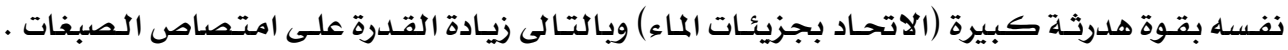

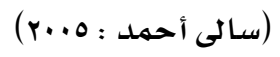

rقوة الشد (كجم) :

أولا : قوة الشد فى اتجاه السداء :

جدول ( IV ) اختبار LSD للمقارنات المتعددة لتأثير تركيز الصودا الكاوية على قوة الشد في اتجاه السداء

\begin{tabular}{|c|c|c|c|c|c|c|c|c|}
\hline \multicolumn{3}{|c|}{ مصبوغ وممرسر } & \multirow{3}{*}{ مصبوغ بلدون مرسرة } & \multicolumn{3}{|c|}{ أبيض وممرسر } & \multirow{3}{*}{\multicolumn{2}{|c|}{ سل ساء }} \\
\hline \multirow{9}{*}{ r صودا • ro } & صودا .. r & صودا . 10 & & صودا PO ro & صودا •. p & صودا •10 & & \\
\hline & $68.000=p$ & $65.000=\mathrm{P}$ & & $70.000=A$ & $66.000=\mathrm{p}$ & $62.000=\mathrm{p}$ & & \\
\hline & & & & & & & صودا 10. & \multirow{3}{*}{ وممرسر } \\
\hline & & & & & & $* * 4.000$ & 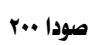 & \\
\hline & & & & & $* * 4.000$ & $* * 8.000$ & صودا • ص ro & \\
\hline & & & & $* * 12.000$ & $* * 8.000$ & $* * 4.000$ & \multicolumn{2}{|c|}{ مصبوغ بلدون مرسرة } \\
\hline & & & $* * 7.000$ & $* * 5.000$ & $* 1.000$ & $* * 3.000$ & صودا •10 & \multirow{3}{*}{ مصربرغ } \\
\hline & & $* * 3.000$ & $* * 10.000$ & $* 2.000$ & $* 2.000$ & $* * 6.000$ & صودا .. P P & \\
\hline & $* * 10.000$ & $* * 13.000$ & $* * 20.000$ & $* * 8.000$ & $* * 12.000$ & $* * 16.000$ & 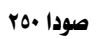 & \\
\hline
\end{tabular}

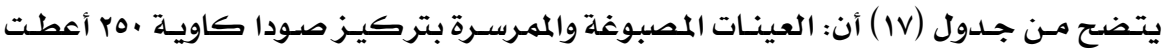

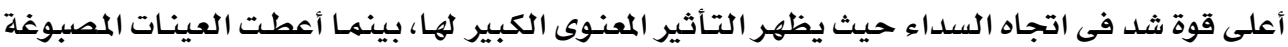




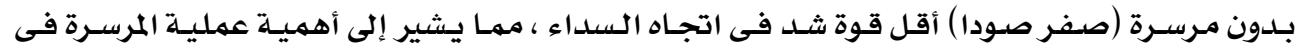
تحسين قوة الشد فى اتجاه السداء . ثانيا : قوة الشد فى اتجاه اللحمة : جدول ( 1 ) ) اختبار LSD للمقارنات المتعددة لتأثير تركيز الصودا الكاوية على قوة الشد في اتجاه اللحمة

\begin{tabular}{|c|c|c|c|c|c|c|c|c|}
\hline \multicolumn{3}{|c|}{ مصببغ وممرسر } & \multirow{3}{*}{\begin{tabular}{|c|} 
مصبوغ بلدون مرسرة \\
مفر = صودا 54.100 \\
\end{tabular}} & \multicolumn{3}{|c|}{ أبيض وممرسر } & \multirow{3}{*}{\multicolumn{2}{|c|}{ لحمة }} \\
\hline \multirow{9}{*}{ 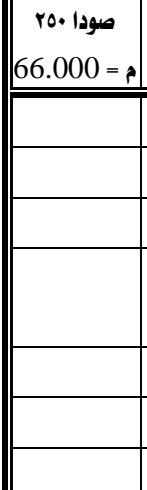 } & صودا .. r & صودا .10 & & صودا • ص ro & صودا . r T & صودا • 10 & & \\
\hline & $59.200=$ & $55.000=$ & & $59.000=A$ & $56.000=p$ & $54.000=\rho$ & & \\
\hline & & & & & & & صودا •10 & \multirow{3}{*}{ وممرسر } \\
\hline & & & & & & $* 2.000$ & صودا .. p & \\
\hline & & & & & $* * 3.000$ & $* * 5.000$ & صودا PO ro & \\
\hline & & & & $* * 4.900$ & *1.900 & -0.100 & \multicolumn{2}{|c|}{ مصبوغ بدون مرسرة } \\
\hline & & & -0.900 & $* * 4.000$ & $* 1.000$ & $* 1.000$ & صودا +10 & \multirow{3}{*}{ مصبوغ } \\
\hline & & $* * 4.200$ & $* * 5.100$ & -0.200 & $* * 3.200$ & $* * 5.200$ & صودا ..r & \\
\hline & $* * 6.800$ & $* * 11.000$ & $* * 11.900$ & $* * 7.000$ & $* * 10.000$ & $* * 12.000$ & صودا ro r p & \\
\hline
\end{tabular}

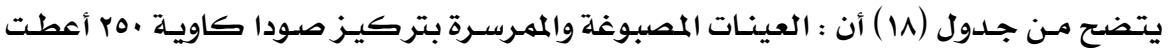

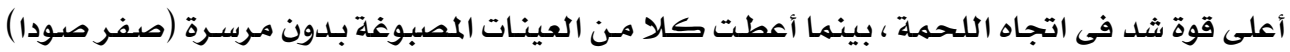

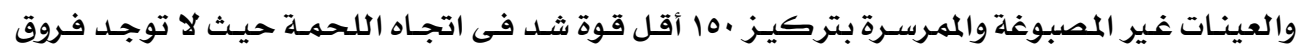

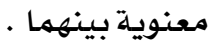

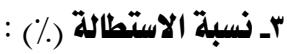
أولا : نسبة الاستطالة فى اتجاه السداء : جدول (19) اختبارLSD للمقارنات المتعددة لتأثير تركيز الصودا الكاوية على نسبـة الاستطالة فى اتجاه السداء

\begin{tabular}{|c|c|c|c|c|c|c|c|c|}
\hline \multicolumn{3}{|c|}{ مصبوغ ومهرسر } & \multirow{3}{*}{ مصبوغ بلدون مرسرة } & \multicolumn{3}{|c|}{ أبيض ومهرسر } & \multirow{3}{*}{\multicolumn{2}{|c|}{ سلداs }} \\
\hline صودا . PO & صودا •.r & صودا •10 & & صودا PO ro & & & & \\
\hline \multirow[t]{8}{*}{$17.500=$} & $16.510=$ & $16.100=$ & & $16.500=$ ? & $16.000=P$ & $15.000=$ a & & \\
\hline & & & & & & & صودا •10 & \multirow{3}{*}{ وممرسي } \\
\hline & & & & & & $* 1.000$ & صودا +.r & \\
\hline & & & & & $* 0.500$ & $* * 1.500$ & صودا .0 r & \\
\hline & & & & -0.020 & $* 0.520$ & $* * 1.520$ & \multicolumn{2}{|c|}{ مصبوغ بلدوز مرسرة } \\
\hline & & & $* 0.420$ & $* 0.400$ & -0.100 & $* 1.100$ & صودا -10 & \multirow{3}{*}{ ومبوغ } \\
\hline & & $* 0.410$ & -0.010 & -0.010 & $* 0.510$ & $* * 1.510$ & صودا +.r & \\
\hline & *0.990 & $* * 1.400$ & $* 0.980$ & $* 1.000$ & $* * 1.500$ & $* * 2.500$ & صودا . ص ro & \\
\hline
\end{tabular}




$$
\text { يتضح من جدول (19) أن: }
$$

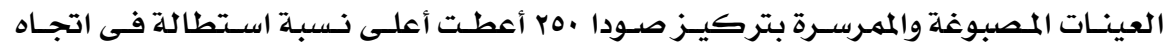

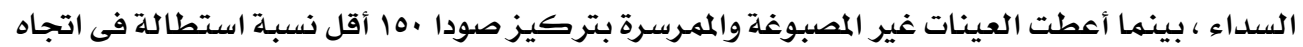

ثانيا : نسبة الاستطالة فى اتجاه اللحمة :

جدول( • اختبار LSD للمقارنات المتعددة لتأثير تركيز الصودا الكاويةعلى نسبة الاستطالة فى اتجاه اللحمة

\begin{tabular}{|c|c|c|c|c|c|c|c|c|}
\hline \multicolumn{3}{|c|}{ مصبوغ وممرسر } & \multirow{3}{*}{ مصبوغ بلدون مرسرة } & \multicolumn{3}{|c|}{ أبيض وممرسر } & \multirow{3}{*}{\multicolumn{2}{|c|}{ لحمة }} \\
\hline صودا PO P & صودا •.r & صودا +10 & & صودا +ro & صودا •.r & صودا •10 & & \\
\hline \multirow[t]{8}{*}{$19.200=$ P } & $17.100=$ & $17.550=$ & & $19.000=P$ & $17.000=P$ & $16.500=?$ & & \\
\hline & & & & & & & صودا •10 & \multirow{3}{*}{ بيض وممرسر } \\
\hline & & & & & & $* 0.500$ & صودا ..r & \\
\hline & & & & & $* * 2.000$ & $* * 2.500$ & صودا . ص ro & \\
\hline & & & & $* * 1.500$ & $* 0.500$ & $* 1.000$ & \multicolumn{2}{|c|}{ مصبوغ بلدون مرسرة } \\
\hline & & & -0.050 & $* * 1.450$ & $* 0.550$ & $* 1.050$ & صودا •10 & \multirow{3}{*}{ ومبرغ } \\
\hline & & $* 0.450$ & $* 0.400$ & $* * 1.900$ & -0.100 & $* 0.600$ & صودا •.r & \\
\hline & $* * 2.100$ & $* * 1.650$ & $* * 1.700$ & -0.200 & $* * 2.200$ & $* * 2.700$ & صودا +0 ro & \\
\hline
\end{tabular}

يتــح مـن جـدول ( •r ) : عـدم وجـود فـروق بـين العينـات المصبـوغة والممرسـرة بتركيـز صـودا

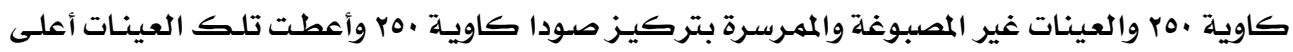
نسبـة استطالة فى اتجـاه اللحمهة ، بينهما أعطت العينات غير المصبوغة والممـرسـرة بتركيز صودا كاويـة

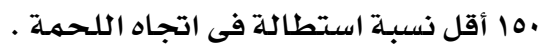

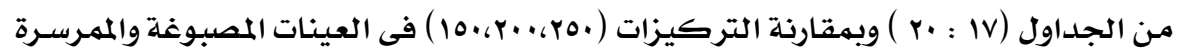
بنفس التركيزات فى العينات غير المصبوغة والممـرسرة نجد أن العينات المصبيوغة والممـرسرة أعطت إمـا

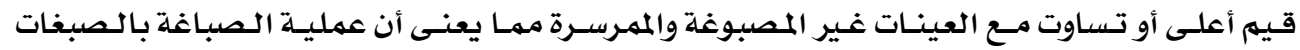

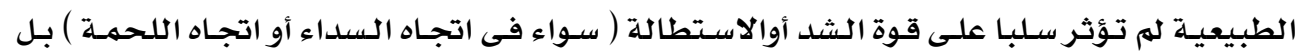




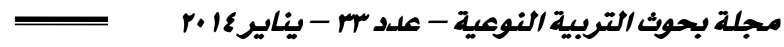

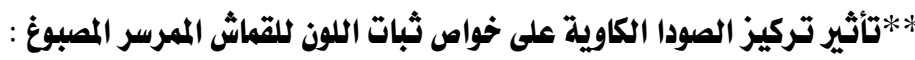

جدول ( ا Y ) تحليل التباين لتأثير تركيز الصودا الكاوية على خواص الثبات للقماش الممرسر المصبوغ

\begin{tabular}{|c|c|c|c|c|c|}
\hline الدلالة & قيمة (ف) & درجات الحرية & متوسط المربعات & مجموع المربعات & \\
\hline \multicolumn{6}{|c|}{ الثبات للفسيل } \\
\hline \multirow{2}{*}{0.0101} & \multirow{2}{*}{6.006} & 3 & 6.507 & 19.520 & بين المجموعات \\
\hline & & 8 & 1.083 & 8.667 & داخل المجموعات \\
\hline & & 11 & & 28.187 & المجموع \\
\hline \multicolumn{6}{|c|}{ الثبات للاحتكاك جاف } \\
\hline \multirow{2}{*}{0.0101} & \multirow{2}{*}{5.468} & 3 & 6.726 & 20.177 & بين المجموعات \\
\hline & & 8 & 1.230 & 9.840 & داخل المجموعات \\
\hline & & 11 & & 30.017 & المجموع \\
\hline \multicolumn{6}{|c|}{ رطب } \\
\hline \multirow{2}{*}{0.0101} & \multirow{2}{*}{5.590} & 3 & 5.795 & 17.385 & بين المجموعات \\
\hline & & 8 & 1.037 & 8.293 & داخل المجموعات \\
\hline & & 11 & & 25.678 & المجموع \\
\hline \multicolumn{6}{|c|}{ الثبات للعرق قلوى } \\
\hline \multirow{3}{*}{0.0101} & \multirow{2}{*}{5.501} & 3 & 6.766 & 20.298 & بين المجموعات \\
\hline & & 8 & 1.230 & 9.840 & داخل المجموعات \\
\hline & & 11 & & 30.138 & المجموع \\
\hline \multicolumn{6}{|c|}{ حامضى } \\
\hline \multirow{2}{*}{0.0101} & \multirow{2}{*}{5.456} & 3 & 6.733 & 20.199 & بين المجموعات \\
\hline & & 8 & 1.234 & 9.872 & داخل المجموعات \\
\hline & & 11 & & 30.071 & المجموع \\
\hline \multicolumn{6}{|c|}{ الثبات للضوs } \\
\hline \multirow{3}{*}{0.0101} & \multirow{2}{*}{6.964} & 3 & 16.975 & 50.925 & بين المجموعات \\
\hline & & 8 & 2.438 & 19.500 & داخل المجموعات \\
\hline & & 11 & & 70.425 & المجموع \\
\hline
\end{tabular}

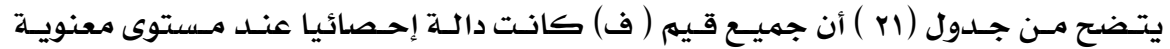

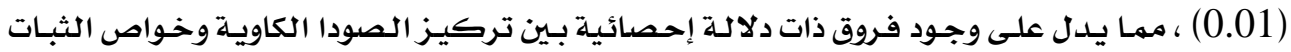

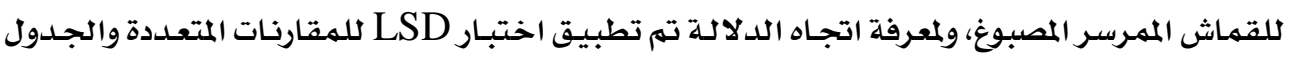
التالي يوضـح ذلك : 


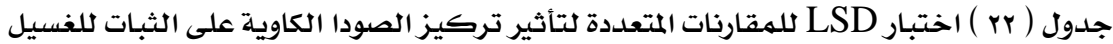

\begin{tabular}{|c|c|c|c|c|c|}
\hline \multicolumn{3}{|c|}{ مصببغ وممرسر } & مصبوغ بدون مرسرة & \multirow{3}{*}{\multicolumn{2}{|c|}{ الثبات للفسيل }} \\
\hline صودا ro ro & Pودا P. P & صودا •10 & (صفر صودا) & & \\
\hline \multirow[t]{5}{*}{$4.000=$ P } & $3.490=p$ & $3.000=p$ & $3.500=A$ & & \\
\hline & & & & صفر صودا) & مصبوغ بلدون مرر \\
\hline & & & $* 0.500$ & صودا .10 & \multirow{3}{*}{ مصبوغ وممرسر } \\
\hline & & $* 0.490$ & -0.010 & صودا r. صو & \\
\hline & $* 0.510$ & $* * 1.000$ & $* 0.500$ & صودا . ص ro & \\
\hline
\end{tabular}

$$
\text { يتضح من جدول (rr) أن: }
$$

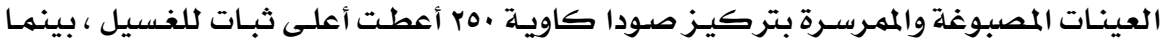

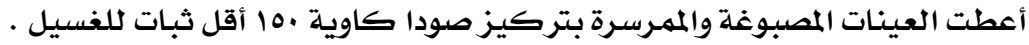

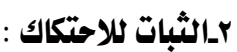

أولا : الثبات كلاحتكاك (الجاف ) :

جدول ( س ) اختبار LSD للمقارنات المتعددة لتأثير تركيز الصودا الكاوية على الثبات للاحتكاك (الجاف)

\begin{tabular}{|c|c|c|c|c|c|}
\hline \multicolumn{3}{|c|}{ مصبوغ وممرسر } & مصبوغ بلدون مرسرة & \multirow{3}{*}{\multicolumn{2}{|c|}{ جاف }} \\
\hline 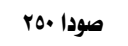 & صودا •.. P & صودا •10 & (صفر صودا) & & \\
\hline \multirow[t]{5}{*}{$3.980=p$} & $3.000=p$ & $3.970=p$ & $3.960=$ & & \\
\hline & & & & صفر صودا) & مصببوغ بدون مرة \\
\hline & & & -0.010 & صودا .10 & \multirow{3}{*}{ مصبوغ وممرسر } \\
\hline & & $* * 0.970$ & $* * 0.960$ & صودا ب. r & \\
\hline & $* * 0.980$ & -0.010 & -0.020 & صودا PO P & \\
\hline
\end{tabular}

يتضح من جدول (r) :

عدم وجود فروق بـين العينـات المصبوغة والممبرسـرة بكل مـن تركيز صودا كاويـة . Y0 ،صودا

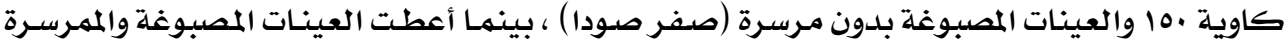

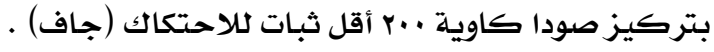


ثانيا : الثبات للاحتكاك ( الرطب ) :

جدول ( ع ) اختبار LSD للمقارنات المتعددة لتأثير تركيز الصودا الكاوية على الثبات للاحتكاك (الرطب)

\begin{tabular}{|c|c|c|c|c|c|}
\hline \multicolumn{3}{|c|}{ مصبوغ وممرسر } & مصبوغ بلدون مرسرة & \multirow{3}{*}{\multicolumn{2}{|c|}{ رطب }} \\
\hline 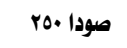 & 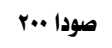 & صودا •10 & (صفر صودا) & & \\
\hline \multirow[t]{5}{*}{$4.000=p$} & $3.980=\mathrm{s}$ & $3.170=\rho$ & $3.140=p$ & & \\
\hline & & & & (صودا) & مصبوغ بدون مرس \\
\hline & & & -0.030 & صودا 10. & \multirow{3}{*}{ تصبوغ وممرسر } \\
\hline & & $* * 0.810$ & $* * 0.840$ & 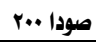 & \\
\hline & -0.020 & $* * 0.830$ & $* * 0.860$ & صودا ro. r r & \\
\hline
\end{tabular}

يتضح من جدول (צ) :

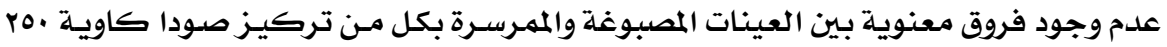

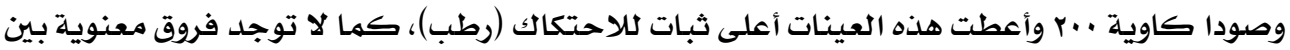

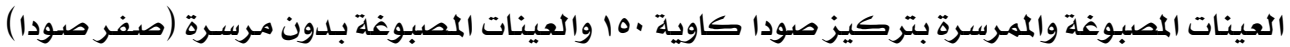

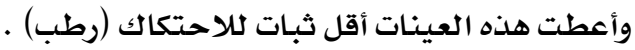

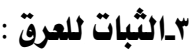
أولا : الثبات للعرق (قلوى) :

جدول ( ب ) اختبار LSD للمقارنات المتعددة لتأثير تركيز الصودا الكاوية على الثبات للعرق (قلوى)

\begin{tabular}{|c|c|c|c|c|c|}
\hline & مصبوغ وممري & & مصبوغ بلدون مرسرة & \multirow{3}{*}{\multicolumn{2}{|c|}{ 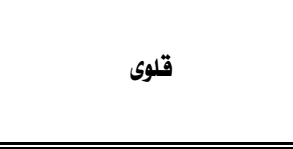 }} \\
\hline صودا • ص ro & 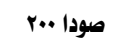 & صودا •10 & (صفر صودا) & & \\
\hline \multirow[t]{5}{*}{$3.970=\mathrm{R}$} & $3.990=p$ & $3.100=p$ & $4.000=p$ & & \\
\hline & & & & \multicolumn{2}{|c|}{ مصبوغ بلدون مرسرة (صفر صودا) } \\
\hline & & & $* * 0.900$ & صودا •10 & \multirow{3}{*}{ وممبرغ } \\
\hline & & $* * 0.890$ & -0.010 & 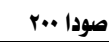 & \\
\hline & -0.020 & $* * 0.870$ & -0.030 & Pودا Po ro & \\
\hline
\end{tabular}

$$
\text { يتضح من جدول (ro) : }
$$

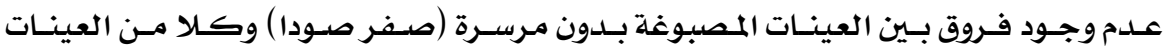

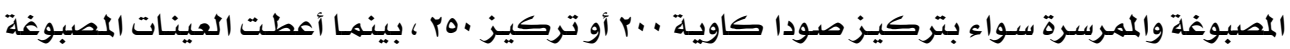
والممرسرة بتركيز صودا كاوية لم 10 أقل ثبات للعرق(قلوىى). 
لـتأثير طروف عملية المرسرة على تحسين خواص أقهشة مكملات /لملابس المصبوغة بالصبغات الطبيعية

ثانيا : الثبات للعرق ( حامضى ) :

جدول ( ب r ) اختبار LSD للمقارنات المتعددة لتأثير تركيز الصودا الكاوية على الثبات للعرق (حامضى)

\begin{tabular}{|c|c|c|c|c|c|}
\hline \multicolumn{3}{|c|}{ مصبوغ وممرسر } & مصبوغ بدون مرسرة & \multirow{3}{*}{\multicolumn{2}{|c|}{ حامضى }} \\
\hline صودا • صو r & 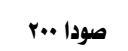 & صودا •10 & (صفر صودا) & & \\
\hline \multirow[t]{5}{*}{$4.000=p$} & $3.960=p$ & $3.000=p$ & $3.530=p$ & & \\
\hline & & & & صودا) & مصبوغ بلدون مرس \\
\hline & & & $* 0.530$ & صودا +10 & \multirow{3}{*}{ مصبوغ وممرسر } \\
\hline & & $* * 0.960$ & $* 0.430$ & Pودا •. Pود & \\
\hline & -0.040 & $* * 1.000$ & $* 0.470$ & صودا + صو & \\
\hline
\end{tabular}

يتضح من جدول (דr) :

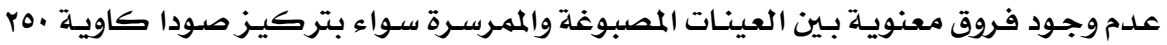

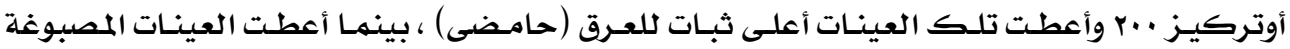

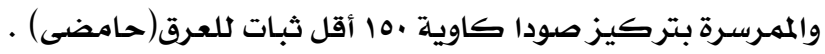

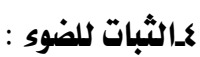

جدول ( LSD للمقارنات المتعددة لتأثير تركيز الصودا الكاوية على الثبات للضوء

\begin{tabular}{|c|c|c|c|c|c|}
\hline \multicolumn{3}{|c|}{ مصبوغ وممرسر } & مصبوغ بلدون مرسرة & \multirow{3}{*}{\multicolumn{2}{|c|}{ الثبات للضوs }} \\
\hline ro. صودا ro & صودا .. P & صودا . 10 & (صفر صودا) & & \\
\hline \multirow{5}{*}{$6.940=$} & $6.000=p$ & $5.110=p$ & $5.990=$ & & \\
\hline & & & & فر صودا) & مصبوغ بلدون مرا \\
\hline & & & $* * 0.880$ & صودا .10 & \multirow{3}{*}{ مصببوغ وممرسر } \\
\hline & & $* * 0.890$ & -0.010 & صودا •. r & \\
\hline & $* * 0.940$ & $* * 1.830$ & $* * 0.950$ & ro. صودا ro & \\
\hline
\end{tabular}

يتضح من جدول (rV) أن :

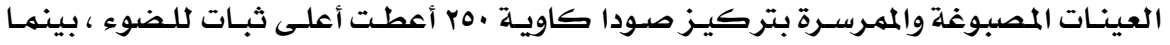

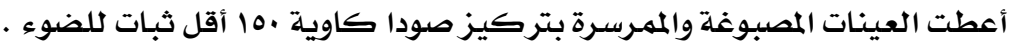




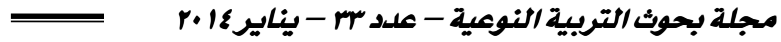

**تقييي الجودة الكلية لتأثير تركيز الصودا الكاوية على الخـواص الطبيعيـة والميكانيكيـة وكفـاءة الـصباغة

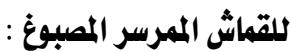

جدول(ץ (ب)تقييم الجودة الكلية لتأثير تركيز الصودا الكاوية على الخواص الطبيعية والميكانيكية وكفاءة الصباغة للقماش الممرسر المصبوغ

\begin{tabular}{|c|c|c|c|c|c|c|c|c|c|c|c|c|c|c|}
\hline \multirow[t]{2}{*}{ |الترتيب } & \multirow{2}{*}{ الجتييم } & \multirow{2}{*}{ الثبات } & \multicolumn{2}{|c|}{ الثبات للعرق \% } & \multicolumn{2}{|c|}{$\mid \begin{array}{c}\text { الثبات للإحتكاك } \\
\%\end{array}$} & \multirow{2}{*}{ 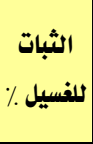 } & \multicolumn{2}{|c|}{ نسبة الاستطالة } & \multicolumn{2}{|c|}{ قوة الشد ٪ } & \multirow{2}{*}{ اللون \% عق } & \multirow[t]{2}{*}{ الاختبار } & \multirow[t]{2}{*}{ العينة } \\
\hline & & & حمضي & قلوي & رطب & جاف & & اللحمة & | السداء & اللحمة & السداء & & & \\
\hline 3 & 795.00 & 75.00 & 70.00 & 80.00 & 70.00 & 70.00 & 70.00 & 87.50 & 82.50 & 67.50 & 72.50 & 50.00 & صودا & مرسبرة \\
\hline 4 & 760.45 & 68.75 & 60.00 & 70.00 & 70.00 & 70.00 & 60.00 & 87.50 & 80.00 & 68.75 & 81.25 & 44.20 & صودا 150 & \\
\hline 2 & 837.19 & 75.00 & 80.00 & 80.00 & 80.00 & 60.00 & 70.00 & 85.00 & 82.50 & 73.75 & 85.00 & 65.94 & صودا 200 & | مصمرسر \\
\hline 1 & 933.75 & 81 & 80 & 80 & 80.00 & 70 & 80 & 95.00 & 87.50 & 82.50 & 97.50 & 100 & صودا 250 & \\
\hline
\end{tabular}

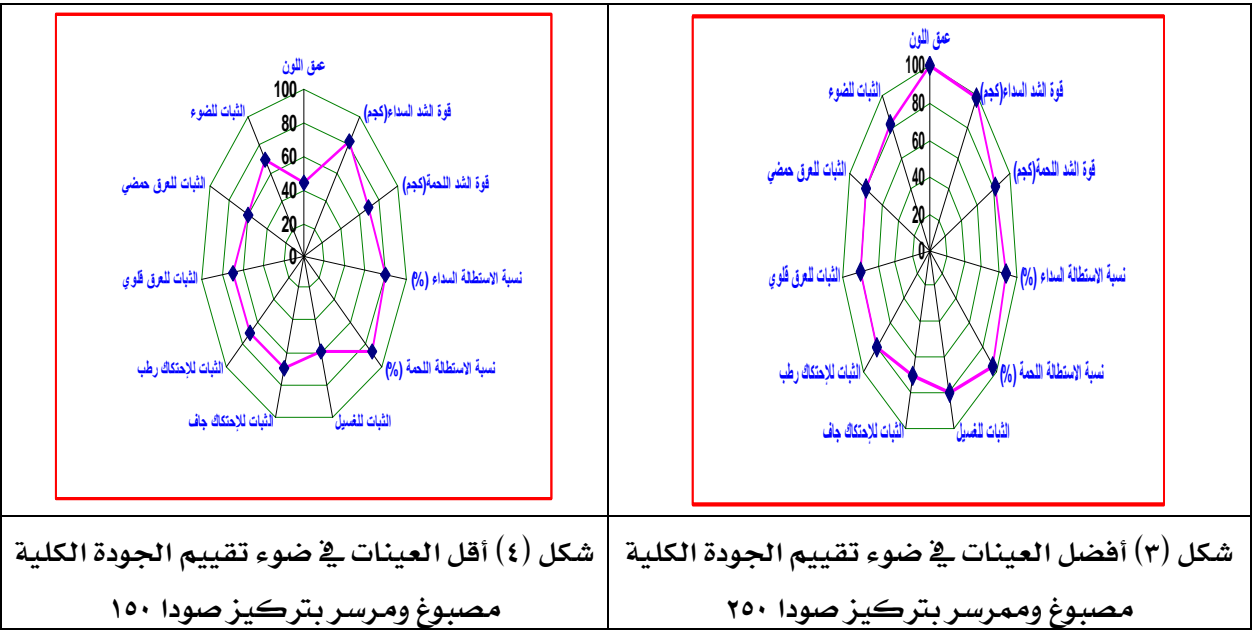

من كل ما سبق : نجد أن العينات المصبوغة والممرسـرة باستخلدام تركيز صـودا كاويـة

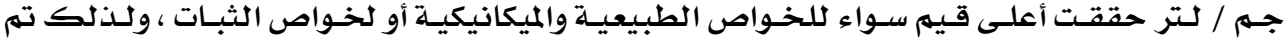

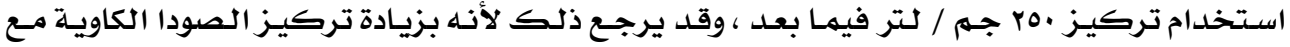

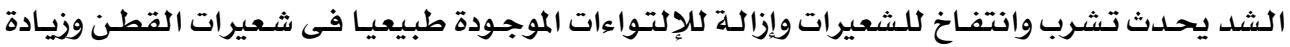

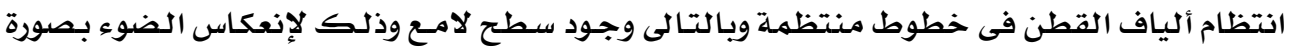




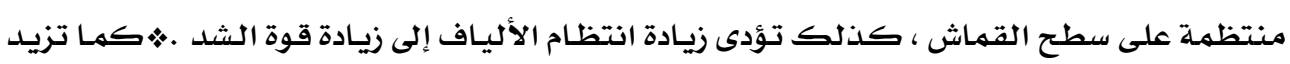

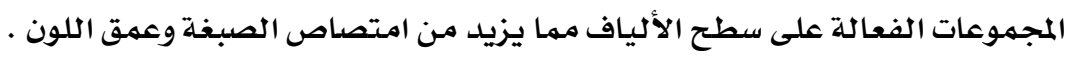
الفرض الثالث : المجوعاث الفعاث

توجد فروق ذات دلالـة إحصائية بـين زمـن الغمـر فـى الصودا الكاويـة والخـواص الطبيعيـة

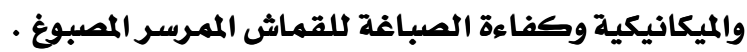

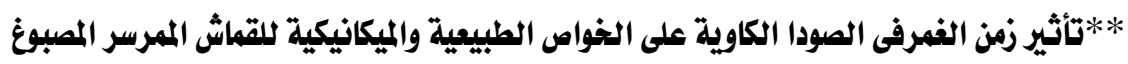

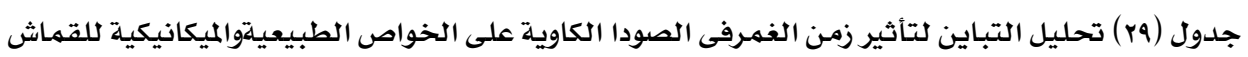

\begin{tabular}{|c|c|c|c|c|c|}
\hline \multicolumn{6}{|c|}{ الممرسر المصبيوغ } \\
\hline الدلالة & قيمة (ف) & درجات الحرية & متوسط المربعات & مجموع المربعات & \\
\hline \multicolumn{6}{|c|}{ ع/S عمق اللون } \\
\hline \multirow{3}{*}{0.01 دال } & \multirow{2}{*}{30.798} & 3 & 30.798 & 92.394 & بين المجموعات \\
\hline & & 8 & 1.000 & 8.000 & داخل المجموعات \\
\hline & & 11 & & 100.394 & المجموع \\
\hline \multicolumn{6}{|c|}{ قوة الشد (كجم) سلداء } \\
\hline \multirow{3}{*}{ - 0.01 دال } & \multirow{2}{*}{32.666} & 6 & 122.886 & 737.317 & بين المجموعات \\
\hline & & 14 & 3.762 & 52.667 & داخل المجموعات \\
\hline & & 20 & & 789.984 & المجموع \\
\hline \multicolumn{6}{|c|}{ لحمة } \\
\hline \multirow{3}{*}{ - 0.01 دال } & \multirow{2}{*}{19.898} & 6 & 251.095 & 1506.571 & بين المجموعات \\
\hline & & 14 & 12.619 & 176.667 & داخل المجموعات \\
\hline & & 20 & & 1683.238 & المجموع \\
\hline \multicolumn{6}{|c|}{ نسبة الاستطالة (\%) سداء } \\
\hline \multirow{2}{*}{0.010} & \multirow{2}{*}{12.216} & 6 & 72.182 & 433.092 & بين المجموعات \\
\hline & & 14 & 5.909 & 82.727 & داخل المجموعات \\
\hline & & 20 & & 515.819 & المجموع \\
\hline \multicolumn{6}{|c|}{ لحمة } \\
\hline \multirow{3}{*}{0.01 دار } & \multirow{2}{*}{11.305} & 6 & 11.305 & 67.831 & بين المجموعات \\
\hline & & 14 & 1.000 & 14.000 & داخل المجموعات \\
\hline & & 20 & & 81.831 & المجموع \\
\hline
\end{tabular}

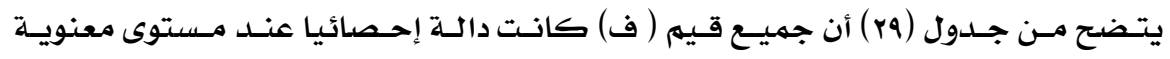

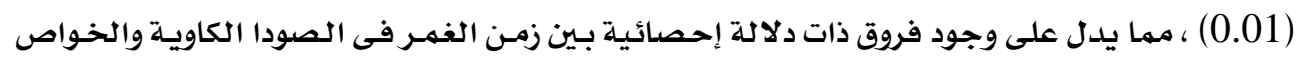

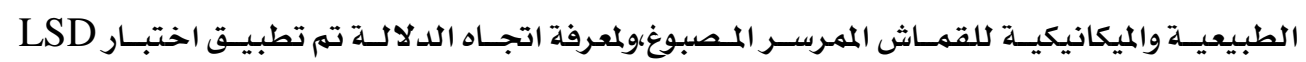

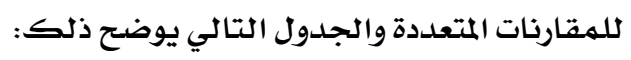


ا ـ عمق اللون K/S :

جدول ( • ) اختبار LSD للمقارنات المتعددة لتأثير زمن الغمر فى الصودا الكاوية على عمق اللون

\begin{tabular}{|c|c|c|c|c|c|}
\hline \multicolumn{3}{|c|}{ مصبوغ وممرسر } & \multirow{2}{*}{ مصبوغ بلدون مرسرة } & \multirow{2}{*}{\multicolumn{2}{|c|}{ عق اللون }} \\
\hline \multirow[t]{5}{*}{ 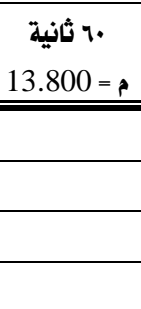 } & م = بـ ثانية & 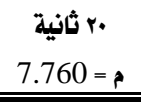 & & & \\
\hline & & & & & مصبوغ بلدو \\
\hline & & & $* 0.860$ & r. ثانية r. & \multirow{3}{*}{ مصبوغ وممرسر } \\
\hline & & $* * 3.560$ & $* * 4.420$ & •ـ ثانية & \\
\hline & $* * 2.480$ & $* * 6.040$ & $* * 6.900$ & ๆ ثانية & \\
\hline
\end{tabular}

يتضـح من جدول ( ب):

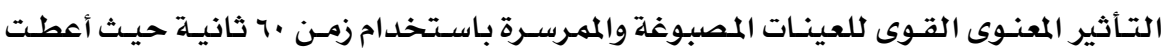

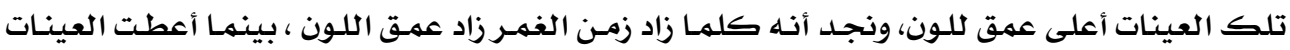

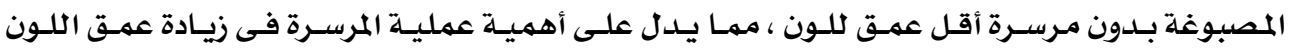

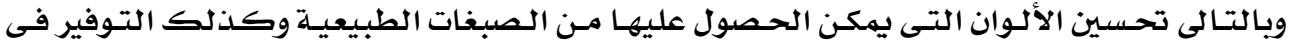

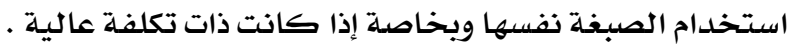

rـ قوة الشلد (كجم) :

أولا : قوة الشد فى اتجاه السداء :

جلدول(اب) اختبار LSD للمقارنات المتعددة لتأثير زمن الغمر فى الصودا الكاويةعلى قوةالشد فى اتجاه السداء

\begin{tabular}{|c|c|c|c|c|c|c|c|c|}
\hline \multicolumn{3}{|c|}{ مصبوغ وممرسر } & \multirow{3}{*}{ مصبوغ بلدون } & \multicolumn{3}{|c|}{ أبيض وممرسر } & \multirow{3}{*}{\multicolumn{2}{|c|}{ سلداs }} \\
\hline \multirow{9}{*}{ 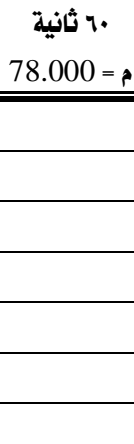 } & •ـ ثانية & r. ثانية r. & & ๆ ثانية . & • ثانية & ثانية r. & & \\
\hline & $74.000=R$ & $67.786=p$ & & $70.000=p$ & $68.000=R$ & $65.000=p$ & & \\
\hline & & & & & & & r ثانية r. & \multirow{3}{*}{ وممرسر } \\
\hline & & & & & & $* * 3.000$ & •ـ ثانية & \\
\hline & & & & & $* 2.000$ & $* * 5.000$ & . ثانية & \\
\hline & & & & $* * 12.000$ & $* * 10.000$ & $* * 7.000$ & \multicolumn{2}{|c|}{ مصبوغ بلدون مرسرة } \\
\hline & & & $* * 9.786$ & $* 2.213$ & -0.213 & $* * 2.786$ & r ثانية r. & \multirow{3}{*}{ مصببوغ } \\
\hline & & $* * 6.213$ & $* * 16.000$ & $* * 4.000$ & $* * 6.000$ & $* * 9.000$ & بـ ثانية & \\
\hline & $* * 4.000$ & $* * 10.213$ & $* * 20.000$ & $* * 8.000$ & $* * 10.000$ & $* * 13.000$ & . ثانية & \\
\hline
\end{tabular}

يتضح من جدول (ابr) أن:

العينات المصبوغة والممرسرة باستخدام زمن لج ثانيلة أعطت أعلى قوة شد فى اتجـاه السـداء ،

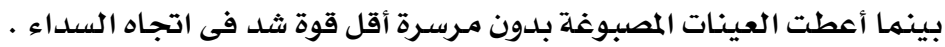


ثانيا : قوة الشد فى اتجاه اللحمة :

جدول(Yr)اختبار LSD للمقارنات المتعددة لتأثير زمن الغمر في الصودا الكاويةعلى قوةالشد في اتجاه اللحمة

\begin{tabular}{|c|c|c|c|c|c|c|c|c|}
\hline \multicolumn{3}{|c|}{ مصبوغ وممرسر } & \multirow{3}{*}{ مصبوغ بلدون } & \multicolumn{3}{|c|}{ أبيض وممرسر } & \multirow{3}{*}{\multicolumn{2}{|c|}{ لحمة ل لحم }} \\
\hline • " ثانية & • • ثانية & . & & • ثانية & • بـ ثانية & r ثانية & & \\
\hline $66.000=p$ & $60.000=p$ & $57.000=p$ & & $59.000=$ & $56.000=\beta$ & $55.000=\mathrm{A}$ & & \\
\hline & & & & & & & r ثانية r. & \\
\hline & & & & & & $* 1.000$ & • ب ثانية & \\
\hline & & & & & $* * 3.000$ & $* * 4.000$ & • • ثانية & \\
\hline & & & & $* * 5.000$ & $* 2.000$ & $* 1.000$ & ن مرسرة & مصبوغ بد \\
\hline & & & $* * 3.000$ & $* 2.000$ & $* 1.000$ & $* 2.000$ & r ثانية r. & \\
\hline & & $* * 3.000$ & $* * 6.000$ & $* 1.000$ & $* * 4.000$ & $* * 5.000$ & •ـ ثانية & \\
\hline & $* * 6.000$ & $* * 9.000$ & $* * 12.000$ & $* * 7.000$ & $* * 10.000$ & $* * 11.000$ & • ^ ثانية & \\
\hline
\end{tabular}

يتضح من جدول (بr) أن:

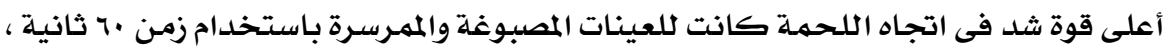

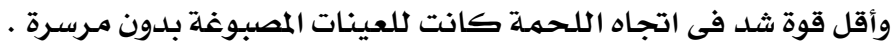

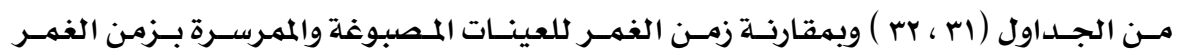

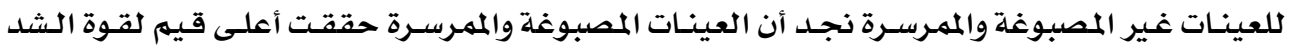

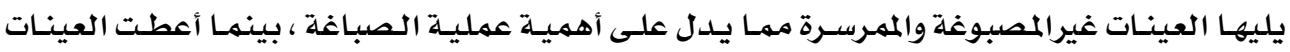

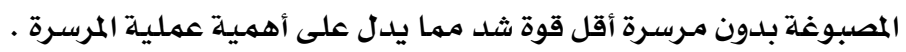

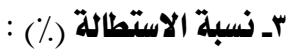

أولا : نسبة الاستطالة فى اتجاه السداء :

جدول (r) (بر)

اختباررLSD للمقارنات المتعددة لتأثير زمن الغمـر في الصودا الكاوية على نسبة الاستطالة فى اتجاه السداء

\begin{tabular}{|c|c|c|c|c|c|c|c|c|}
\hline \multicolumn{3}{|c|}{ مصبوغ وممرسر } & \multirow{3}{*}{ م مببوغ بلدون } & \multicolumn{3}{|c|}{ أبيض وممرسر } & \multirow{3}{*}{\multicolumn{2}{|c|}{ سلداs }} \\
\hline . ث ثانية & بـ ثانية & r ثانية r. & & . ثانية ๆ . & •ـ ثانية & ثانية r. & & \\
\hline \multirow[t]{8}{*}{$17.500=$} & $16.520=A$ & $15.100=A$ & & $16.500=P$ & $15.200=p$ & $15.000=$ R & & \\
\hline & & & & & & & r. & \multirow{3}{*}{ ومهرسر } \\
\hline & & & & & & -0.200 & • • ثانية & \\
\hline & & & & & $* * 1.300$ & $* * 1.500$ & . & \\
\hline & & & & -0.010 & $* * 1.310$ & $* * 1.510$ & \multicolumn{2}{|c|}{ مصببوغ بلدون مرسرة } \\
\hline & & & $* * 1.410$ & $* * 1.400$ & -0.100 & -0.100 & r ثانية r. & \multirow{3}{*}{ مصبرغ } \\
\hline & & $* * 1.420$ & -0.010 & -0.020 & $* * 1.320$ & $* * 1.520$ & • بـ ثانية & \\
\hline & $* 0.980$ & $* * 2.400$ & $* 0.990$ & $* 1.000$ & $* * 2.300$ & $* * 2.500$ & ๆ ثانية & \\
\hline
\end{tabular}




$$
\text { يتضح من جدول (rr) أن: }
$$

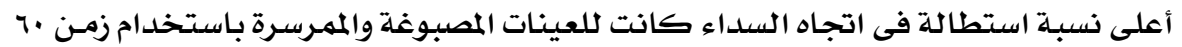

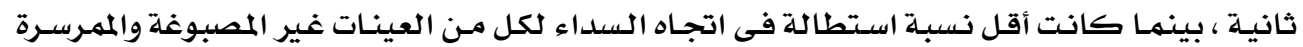

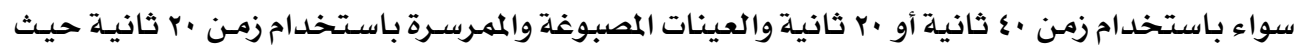

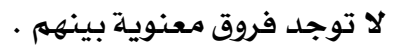

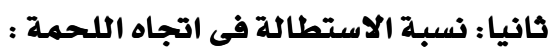

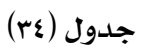

اختبار LSD للمقارنات المتعددة لتأثير زمن الغمـر في الصودا الكاويـة على نسبـة الاستطالة في اتجـاه اللحمـة

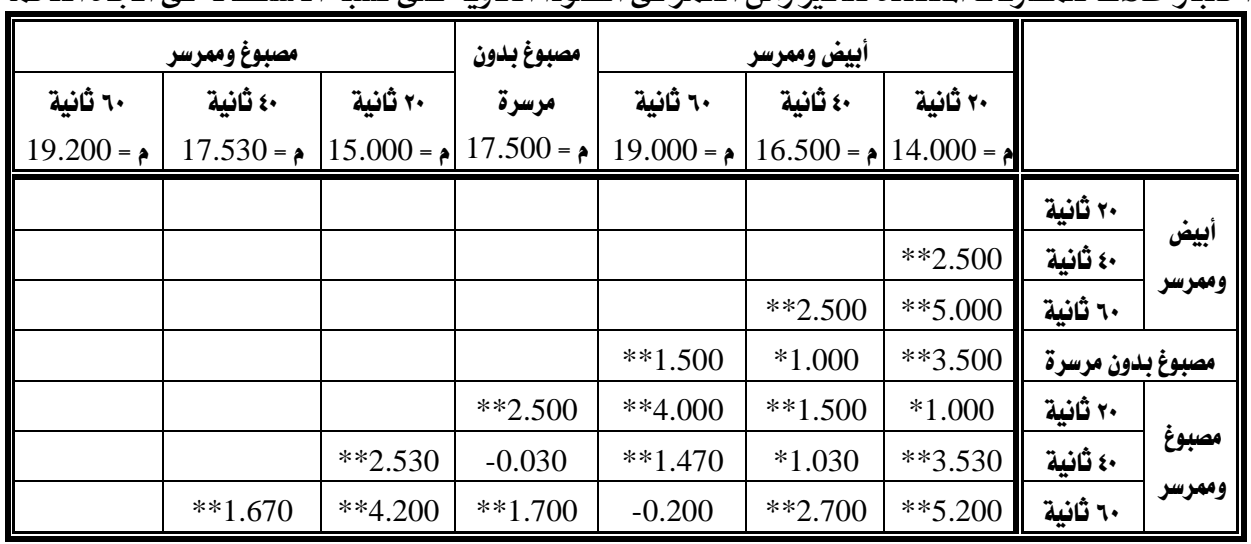

$$
\text { يتضح من جدول (ع) : }
$$

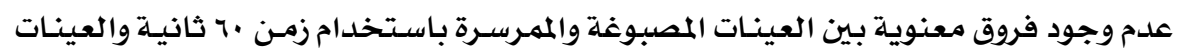

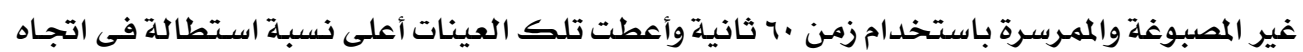

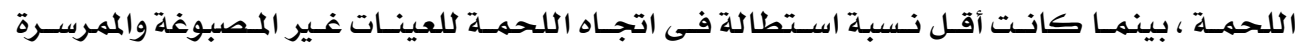

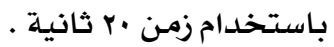




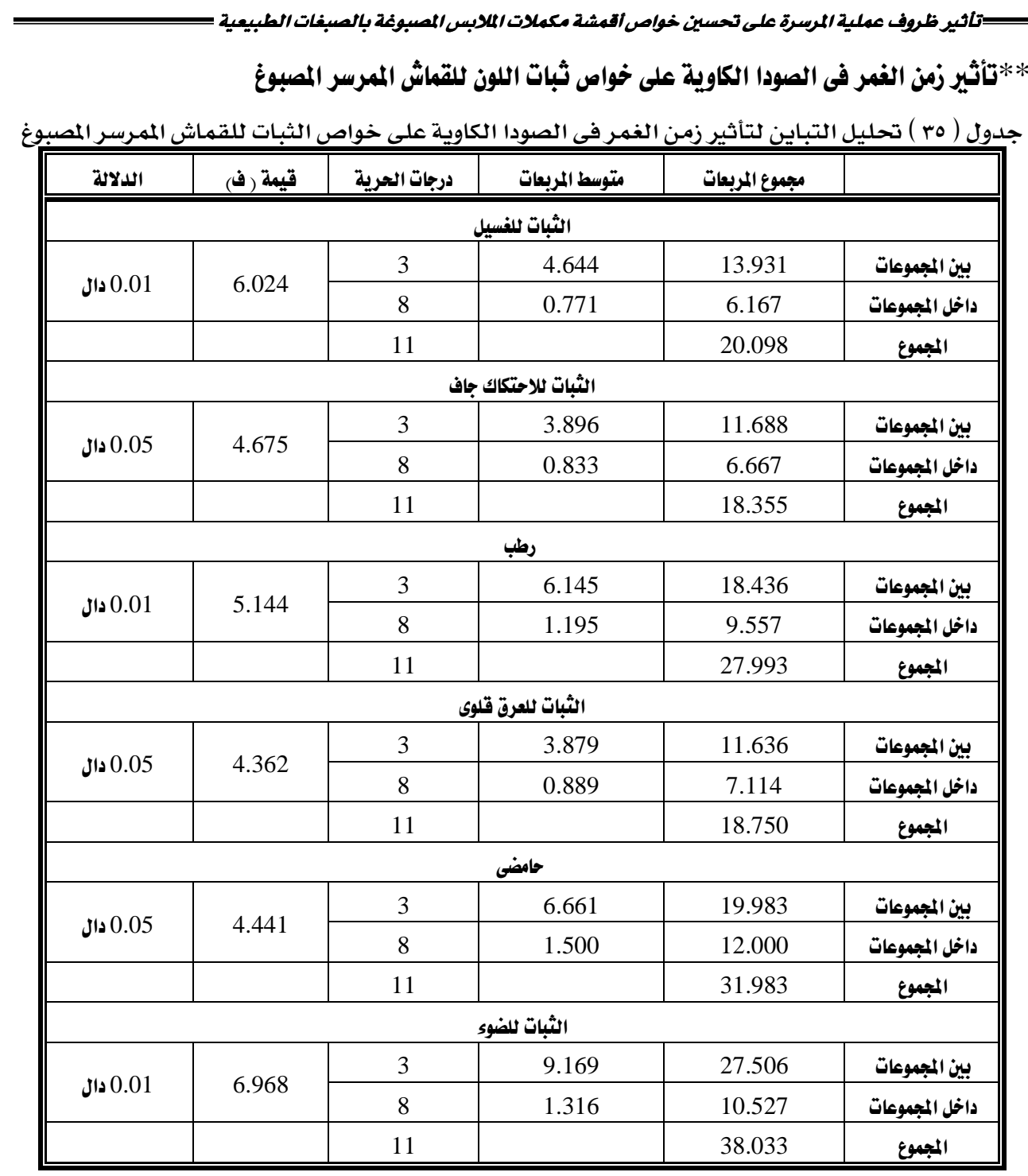

يتضح من جدول (ro ) أن جميع قيم ( ف) كانت دالـة إحصائيا سواءعند مستوى معنويـة

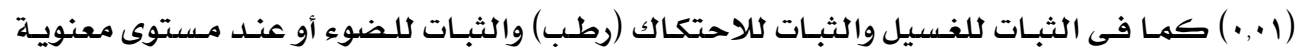

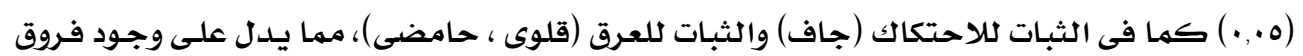

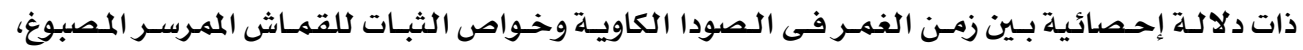

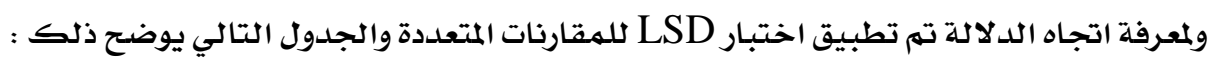




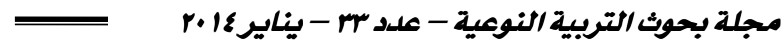

ا_الثبات للفسيل :

جدول ( بr ) اختبار LSD للمقارنات المتعددة لتأثير زمن الغمر في الصودا الكاوية على الثبات للغسيل

\begin{tabular}{|c|c|c|c|c|c|}
\hline \multicolumn{3}{|c|}{ مصبوغ وممرسر } & \multirow{3}{*}{ مصبوغ بلدون } & \multirow{2}{*}{\multicolumn{2}{|c|}{ الثبات للفسيل }} \\
\hline • † ثانية & • • ثانية & •r ثانية & & & \\
\hline $4.000=\beta$ & $3.550=p$ & $3.000=A$ & & & \\
\hline & & & & كرسرة & مصبو \\
\hline & & & $* 0.510$ & •r ثانية & \\
\hline & & $* 0.550$ & -0.040 & •؛ ثانية & \\
\hline & $* 0.450$ & $* * 1.000$ & $* 0.490$ & • 7 ثانية & קו \\
\hline
\end{tabular}

يتضح من جدول (بr) أن:

أعلى ثبات للغسيل كان للعينـات المصبوغة والممرسـرة باسـتخدام زمـن · ج ثانيـة ، وأقل ثبـات

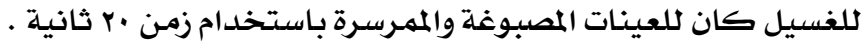

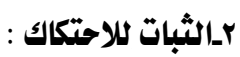

أولا : الثبات كلاحتكاك (جاف) :

جدول(rv) اختبارLSD للمقارنات المتعددة لتأثير زمن الغمر في الصودا الكاوية على الثبات للاحتكاك (جاف)

\begin{tabular}{|c|c|c|c|c|c|}
\hline \multicolumn{3}{|c|}{ مصبوغ وممرسر } & مصببغ بلدون مرسرة & \multirow{2}{*}{\multicolumn{2}{|c|}{ جاف }} \\
\hline \multirow[t]{5}{*}{$\begin{array}{c}\text {. } \\
3.260 \text { = ثانية } \\
\end{array}$} & م = ثـ ثانية & 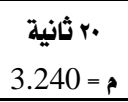 & م = = 3.210 & & \\
\hline & & & & ل برة & مصبوغ بلد \\
\hline & & & -0.030 & r. & \multirow{3}{*}{ مصبوغ وممرسر } \\
\hline & & $* 0.760$ & $* 0.790$ & •ـ ثانية & \\
\hline & $* 0.740$ & -0.020 & -0.050 & • † ثانية & \\
\hline
\end{tabular}

يتضح من جدول (rv) أن:

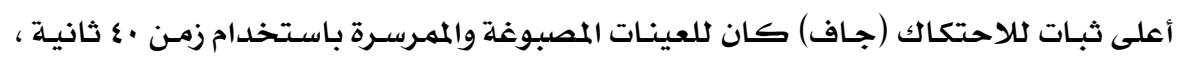

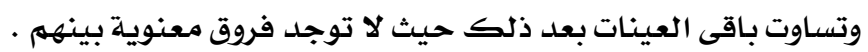


جدول (ی^)اختبارLSDD للمقارنات المتعددة لتأثير زمن الغمر في الصودا الكاوية على الثبات للاحتكاك (رطب)

\begin{tabular}{|c|c|c|c|c|c|}
\hline \multicolumn{3}{|c|}{ مصبوغ وممرسر } & مصبوغ بلدون & \multirow{3}{*}{\multicolumn{2}{|c|}{ رطب }} \\
\hline \multirow{6}{*}{ 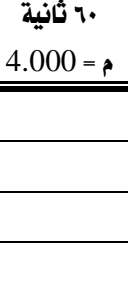 } & • ثـ ثانية & r ب ثانية & مرسرة & & \\
\hline & $3.540=$ & $3.000=p$ & $3.570=$ & & \\
\hline & & & & \multicolumn{2}{|c|}{ مصببوغ بلدون مرسرة } \\
\hline & & & $* 0.570$ & • ب ثانية & \multirow{3}{*}{ مصبوغ وممرسر } \\
\hline & & $* 0.540$ & -0.030 & •؛ ثـ ثنية & \\
\hline & $* 0.460$ & $* * 1.000$ & $* 0.430$ & • ب ثانية & \\
\hline
\end{tabular}

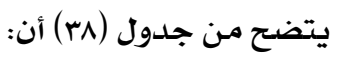

أعلى ثبات للاحتكاك (رطب) كان للعينـات المصبوغة والممبرسـرة باستخدام زمسن •ج ثانيـة ،

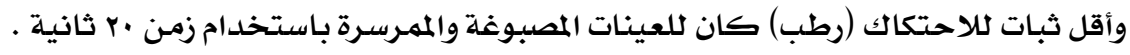

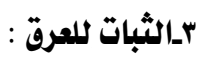

أولا : الثبات للعرق (قلوى) :

جدول (ه) اختبار LSD للمقارنات المتعددة لتأثير زمن الغمر فى الصودا الكاوية على الثبات للعرق (قلوى)

\begin{tabular}{|c|c|c|c|c|c|}
\hline \multicolumn{3}{|c|}{ مصبوغ وممرسر } & مصببوغ بلدون & \multirow{2}{*}{\multicolumn{2}{|c|}{ قلوى }} \\
\hline \multirow[t]{5}{*}{ 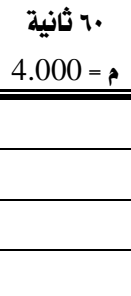 } & م = • ثانية 3.980 & م = • ب ثانية & 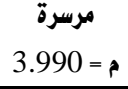 & & \\
\hline & & & & & مصبوغ بدون \\
\hline & & & $* 0.710$ & r. ثانية & \multirow{3}{*}{ مصبوغ وممرسر } \\
\hline & & $* 0.700$ & -0.010 & •ـ ثانية & \\
\hline & -0.020 & $* 0.720$ & -0.010 & . ثانية & \\
\hline
\end{tabular}

يتضح من جدول (rq):

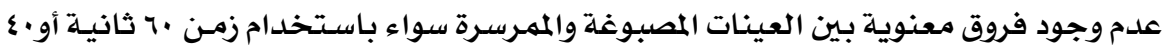

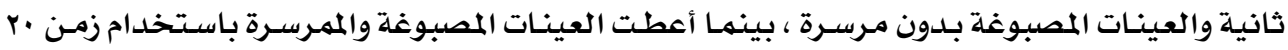

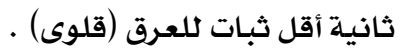


جدول( • ) اختبار LSD للمقارنات المتعددة لتأثير زمن الغمر فى الصودا الكاوية على الثبات للعرق (حامضى)

\begin{tabular}{|c|c|c|c|c|c|}
\hline \multicolumn{3}{|c|}{ مصبوغ وممرسر } & مصنوف غلدهن سوس ق & \multirow{2}{*}{\multicolumn{2}{|c|}{ حامضى }} \\
\hline \multirow[t]{5}{*}{ م = " ب ثانية } & م = • ثـ ثانية 3.980 & $\begin{array}{c}\text { م = r ثانية } \\
3.960\end{array}$ & $3.440=$ & & \\
\hline & & & & & مصبوغ \\
\hline & & & $* 0.520$ & •r ثانية & \multirow{3}{*}{ مصببوغ وممرسر } \\
\hline & & -0.020 & $* 0.540$ & •ـ ثانية & \\
\hline & -0.020 & -0.040 & $* 0.560$ & • ثانية & \\
\hline
\end{tabular}

يتضح من جدول (•ع):

عدم وجود فروق معنوية بين العينات المصبوغة والممرسرة سواء باستخدام زمن لج بـ ثانيـة أو ·ـ

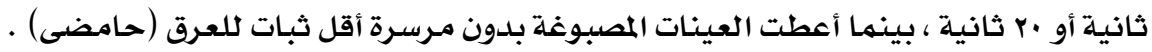

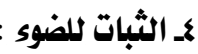

جدول (1) اختبار LSD للمقارنات المتعددة لتأثير زمن الغمر فى الصودا الكاوية على الثبات للضوء

\begin{tabular}{|c|c|c|c|c|c|}
\hline \multicolumn{3}{|c|}{ مصببوغ وممرسر } & \multirow{2}{*}{ مصبوغ بلدون مرسرة } & \multirow{2}{*}{\multicolumn{2}{|c|}{ الثبات للضوs }} \\
\hline \multirow[t]{5}{*}{ 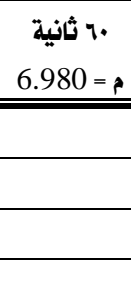 } & م = • ثانية 6.950 & $\begin{array}{c}\text { م = r ثانية } 5.990 \\
\text { • }\end{array}$ & & & \\
\hline & & & & \multicolumn{2}{|c|}{ مصبوغ بلدون مرسرة } \\
\hline & & & -0.010 & r. & \\
\hline & & $\pm \times 0.960$ & $\pm * 0.950$ & •ـ ثانية & \\
\hline & -0.030 & $* * 0.990$ & $* * 0.980$ & • & \\
\hline
\end{tabular}

يتضح من جدول (1) )

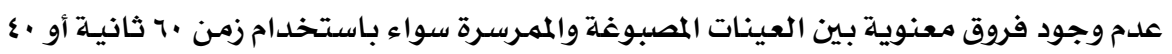

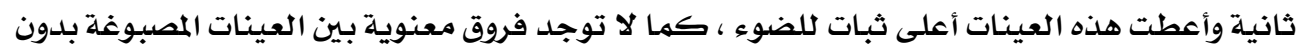

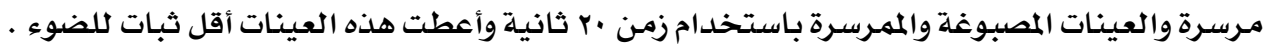


المصبوغ : *تييه الجودة الكلية لتأثير زمن الفمر فى الصودا الكاوية على الخواص الطبيعية والميكانيكية للقماش الممرسر

جدول(ץء) تقييم الجودة الكلية لتأثير زمن الغمرفى الصودا الكاوية على الخواص الطبيعية والميكانيكية

للقهماث الممـرسبر المصبوغ

\begin{tabular}{|c|c|c|c|c|c|c|c|c|c|c|c|c|c|c|}
\hline \multirow[t]{2}{*}{ |الترتيب } & \multirow{2}{*}{ الجتييم } & \multirow{2}{*}{ 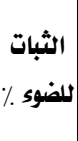 } & \multicolumn{2}{|c|}{ الثبات للعرق ٪ } & \multicolumn{2}{|c|}{ الثبات للإحتكاك } & \multirow{2}{*}{ | } & \multicolumn{2}{|c|}{ نسبة الاستطالة . } & \multicolumn{2}{|c|}{ قوة الشد ٪ } & \multirow{2}{*}{ اللون \% عق } & \multirow{2}{*}{ الاختبار } & \multirow{2}{*}{ العينة } \\
\hline & & & حمضي & قلوي & رطب & جاف & & | اللحمة | & | السلداء & اللحمة & | السلداء & & & \\
\hline 3 & 795.00 & 75.00 & 70.00 & 80.00 & 70.00 & 70.00 & 70.00 & 87.50 & 82.50 & 67.50 & 72.50 & 50.00 & 0 & مرسرة \\
\hline 4 & 777.48 & 75.00 & 80.00 & 70.00 & 60.00 & 70.00 & 60.00 & 75.00 & 75.00 & 71.25 & 85.00 & 56.23 & 20ثانية| & \\
\hline 2 & 880.78 & 81.25 & 80.00 & 80.00 & 70.00 & 80.00 & 70.00 & 87.50 & 82.50 & 75.00 & 92.50 & 82.03 & 40ثانية & \\
\hline 1 & 933.75 & 81.25 & 80.00 & 80.00 & 80.00 & 70.00 & 80.00 & 95.00 & 87.50 & 82.50 & 97.50 & 100 & 60ثانية & \\
\hline
\end{tabular}

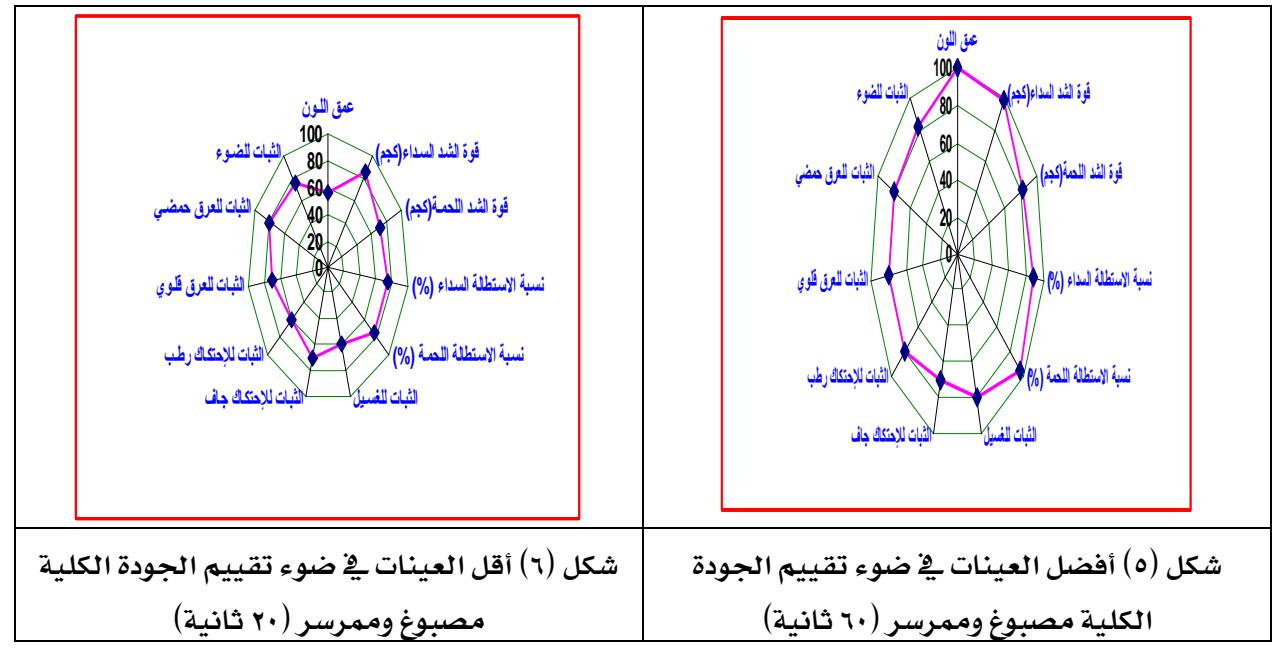

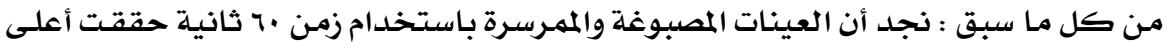

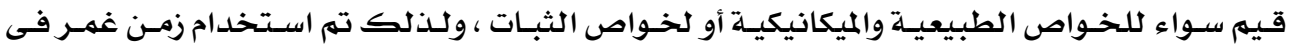

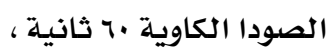

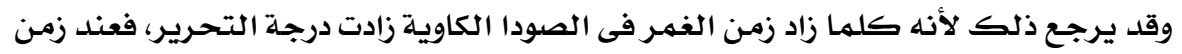

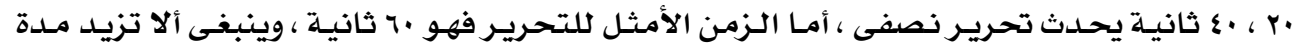

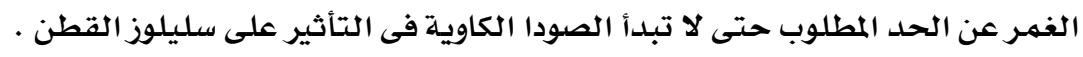




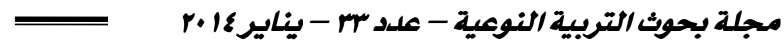

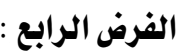

توجـد فـروق ذات دلالــة إحـصائية بـين درجـة حـرارة الـصودا الكاويـة والخـواص الطبيعيـة

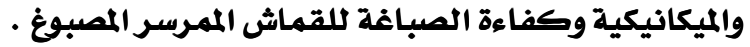

**تأثير درجة حرارة الصودا الكاوية على الخواص الطبيعية والميكانيكية للقماش الممرسر المصبوغ :

جدول(r) تحليل التباين لتأثير درجة حرارة الصودا الكاوية على الخواص الطبيعية والميكانيكية للقماش

\begin{tabular}{|c|c|c|c|c|c|}
\hline \multicolumn{6}{|c|}{ الممـرسر المصبـوغ } \\
\hline الدلالة & قيمة (ف) & درجات الحرية & متوسط المربعات & مجموع المربعات & \\
\hline \multicolumn{6}{|c|}{ ع/S عمق اللون } \\
\hline \multirow{3}{*}{ - 0.01 دال } & \multirow{2}{*}{23.876} & 2 & 30.668 & 61.336 & بين المجموعات \\
\hline & & 6 & 1.284 & 7.707 & داخل المجموعات \\
\hline & & 8 & & 69.043 & المجموع \\
\hline \multicolumn{6}{|c|}{ قوة الشد (كجم) سلداء } \\
\hline \multirow{3}{*}{0.01 دار } & \multirow{2}{*}{35.739} & 4 & 164.400 & 657.600 & بين المجموعات \\
\hline & & 10 & 4.600 & 46.000 & داخل المجموعات \\
\hline & & 14 & & 703.600 & المجهوع \\
\hline \multicolumn{6}{|c|}{ لحمة } \\
\hline \multirow{2}{*}{0.010} & \multirow{2}{*}{33.922} & 4 & 260.067 & 1040.267 & بين المجموعات \\
\hline & & 10 & 7.667 & 76.667 & داخل المجموعات \\
\hline & & 14 & & 1116.934 & المجموع \\
\hline \multicolumn{6}{|c|}{ نسبة الإستطالة (\%) سلداء } \\
\hline \multirow{2}{*}{0.010} & \multirow{2}{*}{12.917} & 4 & 12.917 & 51.666 & بين المجموعات \\
\hline & & 10 & 1.000 & 10.000 & داخل المجموعات \\
\hline & & 14 & & 61.666 & المجموع \\
\hline \multicolumn{6}{|c|}{ لحمة } \\
\hline \multirow{3}{*}{0.01 دال } & \multirow{2}{*}{22.454} & 4 & 28.442 & 113.767 & بين المجموعات \\
\hline & & 10 & 1.267 & 12.667 & داخل المجموعات \\
\hline & & 14 & & 126.434 & المجموع \\
\hline
\end{tabular}

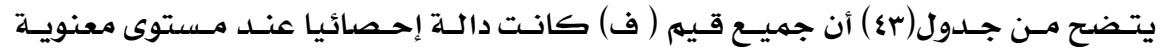

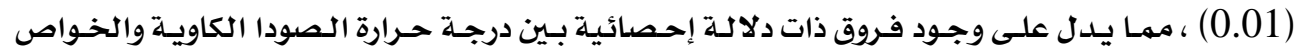

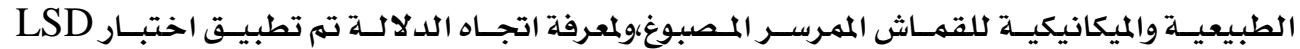

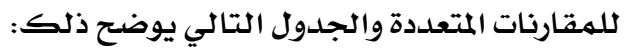


جدول (§ §) اختبار LSD للمقارنات المتعددة لتأثير درجة حرارة الصودا الكاوية على عمق اللون

\begin{tabular}{|c|c|c|c|c|}
\hline \multicolumn{2}{|c|}{ مصبوغ وممرسر } & \multirow{3}{*}{ مصبوغ بلدون مرسرة 6.900 م 6.90} & \multirow{3}{*}{\multicolumn{2}{|c|}{$\begin{array}{c}\text { عمق اللون } \\
\text { K/S }\end{array}$}} \\
\hline \multirow{5}{*}{$10.100=$ p } & درجة حرارة الفرفة & & & \\
\hline & $13.800=A$ & & & \\
\hline & & & \multicolumn{2}{|c|}{ مصبوغ بلدون مرسرة } \\
\hline & & $* * 6.900$ & درجة حرارة الفرفة & مصبوغ \\
\hline & $* * 3.700$ & $* * 3.200$ & ل00 درجة & 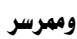 \\
\hline
\end{tabular}

$$
\text { يتضح من جدول (£乏) أن: }
$$

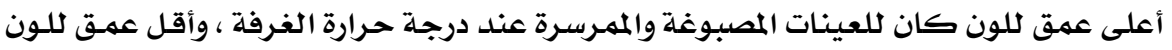

كان للعينات المصبوغة بدون مرسرة ، ويظهر التأثير المعنوى القوى بلين العينات العينات .

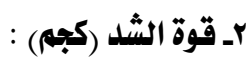

أولا : قوة الشد فى اتجاه السداء :

جدول(هء) اختبار LSD للهقارنات المتعددة لتأثير درجة حرارة الصودا الكاوية على قوة الشد في اتجاه السداء

\begin{tabular}{|c|c|c|c|c|c|c|}
\hline \multicolumn{2}{|c|}{ مصبوغ وممرسر } & \multirow{3}{*}{ مصببوغ بلدون } & \multicolumn{2}{|c|}{ أبيض وممرسر } & \multirow{3}{*}{\multicolumn{2}{|c|}{ سل ساء }} \\
\hline \multirow{7}{*}{ 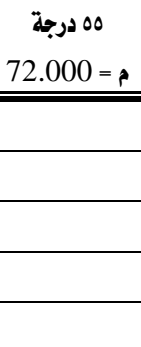 } & درجة حرارة الفرفة & & | 00 درجة & درجة حرارة الغرفة & & \\
\hline & $78.000=$ & & $66.000=p$ & $70.000=$ & & \\
\hline & & & & & درجة حرارة الفرفة & أبيض أبي \\
\hline & & & & $* * 4.000$ & 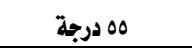 & وممرسر \\
\hline & & & $* * 8.000$ & $* * 12.000$ & \multicolumn{2}{|c|}{ مصبوغ بلدون مرسرة } \\
\hline & & $* * 20.000$ & $* * 12.000$ & $* * 8.000$ & درجة حرارة الفرفة & مصبوغ \\
\hline & $* * 6.000$ & $* * 14.000$ & $* * 6.000$ & $* 2.000$ & مه درجة & 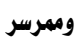 \\
\hline
\end{tabular}

$$
\text { يتضح من جدول (0ء) أن: }
$$

أعلى قوة شد فى اتجاه السداء كانت للعينات المصبوغة والممرسرة عند درجة حسرارة الغرفـة ،

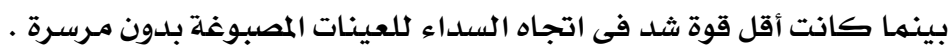


ثانيا : قوة الشد فى اتجاه اللحمة : جلدول( جـ اختبـار LSD للمقارنات المتعددة لتأثير درجـة حرارة الصودا الكاويـة على قوة الشد في اتجاه اللحمـة

\begin{tabular}{|c|c|c|c|c|c|c|}
\hline \multicolumn{2}{|c|}{ مصبوغ وممرسر } & \multirow{3}{*}{ مصبوغ بلدون مرسرة } & \multicolumn{2}{|c|}{ أبيض وممرسر } & \multirow{3}{*}{\multicolumn{2}{|c|}{ لحمة }} \\
\hline \multirow{7}{*}{ 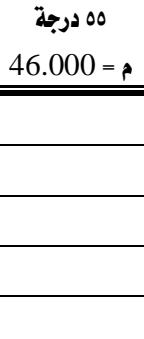 } & درجة حرارة الفرفة & & 00 درجة & درجة حرارة الفرفة & & \\
\hline & $66.000=R$ & & $42.000=\hat{P}$ & $59.000=$ & & \\
\hline & & & & & درجة حرارة الفرفة & \multirow{2}{*}{ أبيض وممرسر } \\
\hline & & & & $* * 17.000$ & ه د درجة & \\
\hline & & & $* * 12.000$ & $* * 5.000$ & \multicolumn{2}{|c|}{ مصبوغ بدون مرسرة } \\
\hline & & $* * 12.000$ & $* * 24.000$ & $* * 7.000$ & درجة حرارة الفرفة & مصبوغ \\
\hline & $* * 20.000$ & $* * 8.000$ & $* * 4.000$ & $* * 13.000$ & مه درجة & وممرسر \\
\hline
\end{tabular}

$$
\text { يتضح من جدول (Tء) أن: }
$$

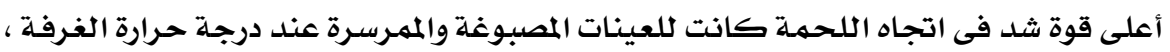

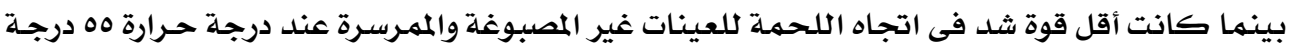

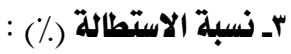

أولا : نسبة الاستطائة فى اتجاه السداء :

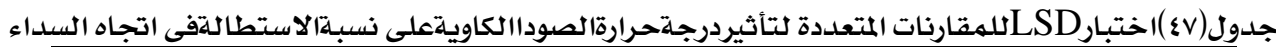

\begin{tabular}{|c|c|c|c|c|c|c|}
\hline \multicolumn{2}{|c|}{ مصبوغ وممرسر } & مصببوغ بلدون & & أبيض وم & \multirow{3}{*}{\multicolumn{2}{|c|}{ 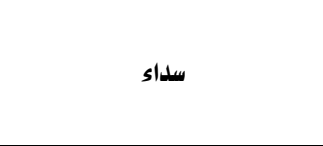 }} \\
\hline $ه 0$ درجة & درجة حرارة الفرفة & مرسرة & ه درجة & درجة حرارة الفرفة & & \\
\hline \multirow[t]{6}{*}{$14.000=p$} & $17.500=$ & $16.510=p$ & $12.500=\beta$ & $16.500=P$ & & \\
\hline & & & & & درجة حرارة الفرفة & \multirow{2}{*}{ أبيض وممرسر } \\
\hline & & & & $* * 4.000$ & ه درجة & \\
\hline & & & $* * 4.010$ & -0.010 & \multicolumn{2}{|c|}{ مصبوغ بلدون مرسرة } \\
\hline & & $* 0.990$ & $* * 5.000$ & $* 1.000$ & درجة حرارة الغرفة & \multirow{2}{*}{ مصبوغ وممرسر } \\
\hline & $* * 3.500$ & $* * 2.510$ & $* * 1.500$ & $* * 2.500$ & ه درجة & \\
\hline
\end{tabular}

$$
\text { يتضح من جدول (ع أن أن: }
$$

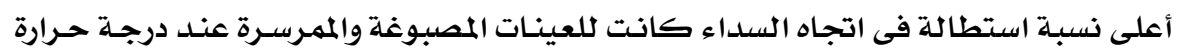

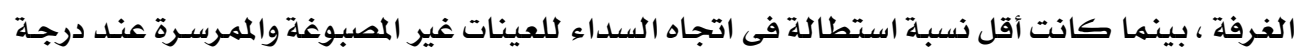
حرارة 00 درجة مئوية . 


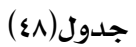

اختبارLSD للمقارنات المتعددة لتأثيردرجةحرارةا الصوداالكاويةعلى نسبـةالاستطالةفى اتجاه اللحمة

\begin{tabular}{|c|c|c|c|c|c|c|}
\hline \multicolumn{2}{|c|}{ مصببوغ وممرسر } & \multirow{3}{*}{ مصبوغ بلدون } & \multicolumn{2}{|c|}{ أبيض وممرسر } & \multirow{3}{*}{\multicolumn{2}{|c|}{ لحمة }} \\
\hline ه درجة & درجة حرارة الفرفة & & ه درجة & درجة حرارة الفرفة & & \\
\hline \multirow[t]{6}{*}{$13.000=$ P } & $19.000=P$ & & $12.500=\hat{P}$ & $18.990=p$ & & \\
\hline & & & & & درجة حرارة الغرفة & \\
\hline & & & & $* * 6.490$ & ه درجة & \\
\hline & & & $* * 5.000$ & $* * 1.490$ & \multicolumn{2}{|c|}{ مصبوغ بلدون مرسرة } \\
\hline & & $* * 1.500$ & $* * 6.500$ & -0.010 & درجة حرارة الفرفة & مصبوغ \\
\hline & $* * 6.000$ & $* * 4.500$ & $* 0.500$ & $* * 5.990$ & ه درجة & ومهرسر \\
\hline
\end{tabular}

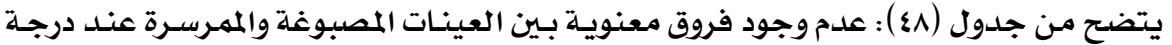

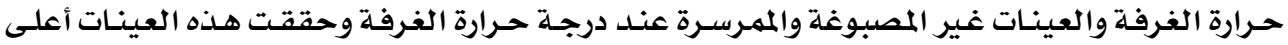

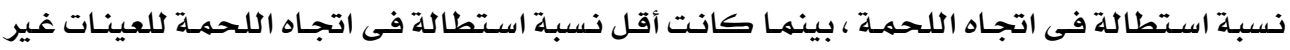

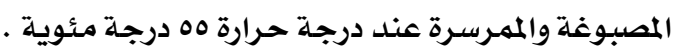

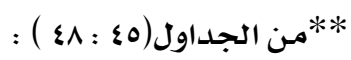

وبهقارنة درجتى حرارة الصودا الكاويـة فى العينـات المصبوغة والممرسـرة بـنفس درجتى الحـرارة

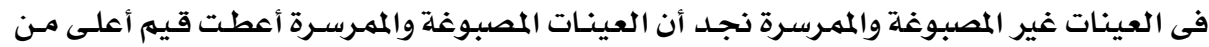

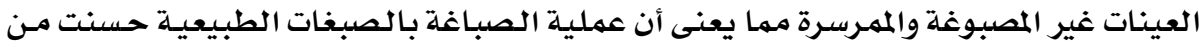

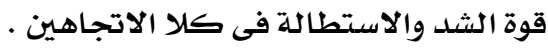

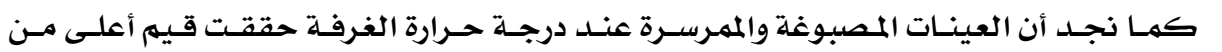

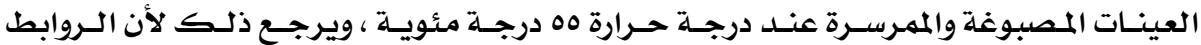

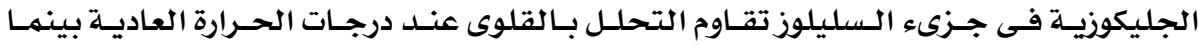

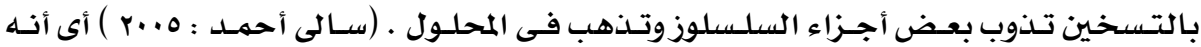

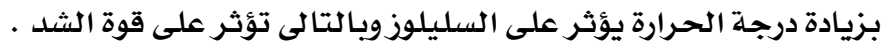




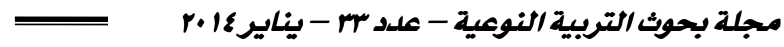

**تأثير درجة حرارة الصودا الكاوية على خواص ثبات اللوذ للقماش الممرسر المصبوغ :

جدول(هء)تحليل التباين لتأثير درجة حرارة الصودا الكاوية على خواص الثبـات للقماش الممرسر المصببوغ

\begin{tabular}{|c|c|c|c|c|c|}
\hline الدلالة & قيمة (ف) & درجات الحرية & متوسط المربعات & مجموع المربعات & \\
\hline \multicolumn{6}{|c|}{ الثبات للفسيل } \\
\hline \multirow{3}{*}{0.01 دال } & \multirow{2}{*}{5.914} & 2 & 4.908 & 9.817 & بين المجموعات \\
\hline & & 6 & 0.830 & 4.980 & داخل المجموعات \\
\hline & & 8 & & 14.797 & المجموع \\
\hline \multicolumn{6}{|c|}{ الثبات للاحتكاك جاف } \\
\hline \multirow{3}{*}{0.0101} & \multirow{2}{*}{6.209} & 2 & 4.918 & 9.836 & بين المجموعات \\
\hline & & 6 & 0.792 & 4.752 & داخل المجموعات \\
\hline & & 8 & & 14.588 & المجموع \\
\hline \multicolumn{6}{|c|}{ رطب } \\
\hline \multirow{3}{*}{0.01 دال } & \multirow{2}{*}{5.008} & 2 & 4.449 & 8.898 & بين المجموعات \\
\hline & & 6 & 0.888 & 5.331 & داخل المجموعات \\
\hline & & 8 & & 14.229 & المجموع \\
\hline \multicolumn{6}{|c|}{ الثبات للعرق قلوى } \\
\hline \multirow{2}{*}{0.640 غير دال } & \multirow{2}{*}{0.480} & 2 & 0.961 & 1.921 & بين المجموعات \\
\hline & & 6 & 2.000 & 12.000 & داخل المجموعات \\
\hline & & 8 & & 13.921 & المجموع \\
\hline \multicolumn{6}{|c|}{ حامضى } \\
\hline \multirow{3}{*}{0.05 دال } & \multirow{2}{*}{3.424} & 2 & 2.317 & 4.635 & بين المجموعات \\
\hline & & 6 & 0.677 & 4.061 & ل \\
\hline & & 8 & & 8.696 & المجموع \\
\hline \multicolumn{6}{|c|}{ الثبات للضوs } \\
\hline \multirow{3}{*}{0.01 داJ } & \multirow{2}{*}{5.310} & 2 & 23.388 & 46.776 & بين المجموعات \\
\hline & & 6 & 4.404 & 26.427 & داخل المجموعات \\
\hline & & 8 & & 73.203 & المجموع \\
\hline
\end{tabular}

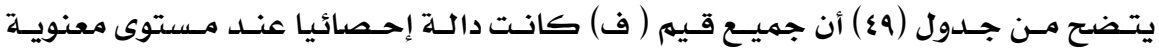

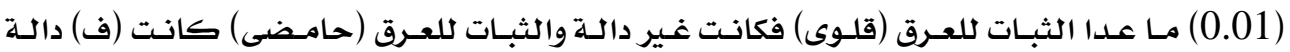

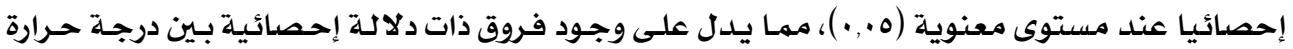

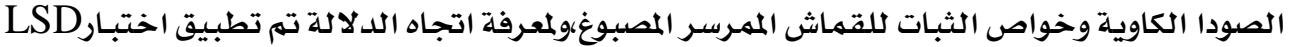

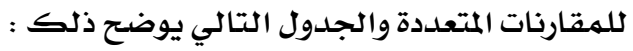


جــول ( •ه ) اختبـار LSD للمقارنات المتعددة لتأثير درجـة حرارة الصودا الكاويـة على الثبـات للغسيل

\begin{tabular}{|c|c|c|c|c|}
\hline \multicolumn{2}{|c|}{ مصبوغ وممرسر } & \multirow{2}{*}{ مصبوغ بلدون مرسرة } & \multirow{2}{*}{\multicolumn{2}{|c|}{ الثبات للفسيل }} \\
\hline \multirow{4}{*}{ 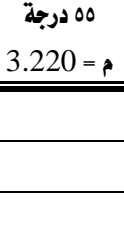 } & درجة حرارة الفرفة & & & \\
\hline & & & \multicolumn{2}{|c|}{ مصبوغ بلدون مرسرة } \\
\hline & & $* * 0.850$ & درجة حرارة الفرفة & \multirow{2}{*}{ مصبوغ وممرسر } \\
\hline & $* 0.780$ & -0.070 & ه درجة & \\
\hline
\end{tabular}

يتضح من جلدول ( .0) أن: العينات المصبوغة والممرسرة عند درجة حـرارة الغرفة أعطت أعلى

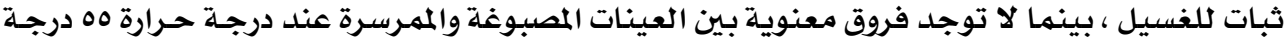
مئوية والعينات المصبوغة بلدون مـرسرة .

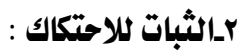

أولا : الثبات كلاحتكاك (جاف) :

جلدول (ه) اختبار LSD للمقارنات المتعددة لتأثير درجة حرارة الصودا الكاوية على الثبات للاحتكاك (جاف)

\begin{tabular}{|c|c|c|c|c|}
\hline \multicolumn{2}{|c|}{ مصبوغ وممرسر } & \multirow{3}{*}{ مصبوغ بلدون مرسرة } & \multirow{3}{*}{\multicolumn{2}{|c|}{ جاف }} \\
\hline ه درجة & درجة حرارة الفرفة & & & \\
\hline \multirow[t]{4}{*}{$4.000=p$} & $3.200=?$ & & & \\
\hline & & & \multicolumn{2}{|c|}{ مصبوغ بلدون مرسرة } \\
\hline & & -0.020 & درجة حرارة الفرفة & مصبوغ \\
\hline & $* * 0.800$ & $* * 0.820$ & مه درجة & وممرسر \\
\hline
\end{tabular}

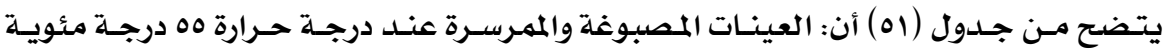
أعطت أعلى ثبات للاحتكاك (جاف) ،بينما لا توجد فروق معنوية بين العينات المصبيوغة والممرسرة عند درجة حرارة الغرفة والعينات المصبيوغة بـدون مـرسـرة . ثانيا : الثبات كلاحتكاك (رطب) :

جلدول (LSD للمقارنات المتعددة لتأثير درجة حرارة الصودا الكاوية على الثبات للاحتكاك (رطب)

\begin{tabular}{|c|c|c|c|c|}
\hline \multicolumn{2}{|c|}{ مصبوغ وممرسر } & \multirow{3}{*}{ مصبوغ بلدون مرسرة } & \multirow{3}{*}{ 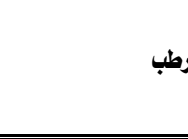 } & \\
\hline 00 درجة & درجة حرارة الفرفة & & & \\
\hline \multirow[t]{4}{*}{$3.000=P$} & $4.000=\hat{R}$ & & & \\
\hline & & & \multicolumn{2}{|c|}{ مصبوغ بلدون مرسرة } \\
\hline & & $\$ 0.490$ & درجة حرارة الفرفة & مصبوغ \\
\hline & \pm 1.000 & \pm 0.510 & مه درجة & وممرسر \\
\hline
\end{tabular}




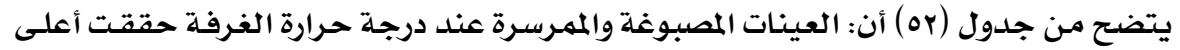

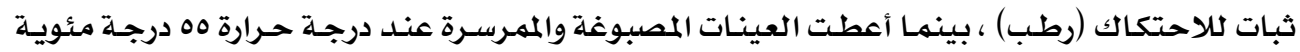

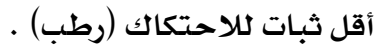
بـالثبات للعرق الثبات للعرق (حامضى) :

جدول (rه ) اختبار LSD للمقارنات المتعددة لتأثير درجة حرارة الصودا الكاوية على الثبات للعرق (حامضى)

\begin{tabular}{|c|c|c|c|c|}
\hline \multicolumn{2}{|c|}{ مصبوغ وممرسر } & \multirow{2}{*}{ مصبوغ بدون مرسرة } & \multirow{2}{*}{\multicolumn{2}{|c|}{ حامضى }} \\
\hline \multirow[t]{4}{*}{$3.950=$} & درجة حرارة الفرفة & & & \\
\hline & & & \multicolumn{2}{|c|}{ مصبوغ بلدون مرسرة } \\
\hline & & $* 0.740$ & درجة حرارة الفرفة & مصبوغ \\
\hline & -0.050 & $* 0.690$ & هه درجة & وممرسر \\
\hline
\end{tabular}

يتضح من جدول (هo):

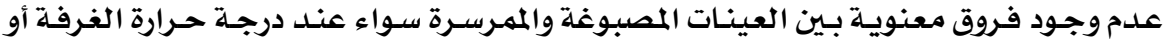

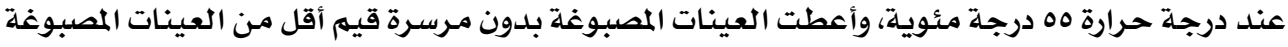
والممرسبرة . كـالثبات للضوك : والمرسرة

\begin{tabular}{|c|c|c|c|c|}
\hline \multicolumn{2}{|c|}{ مصبوغ وممرسر } & \multirow{2}{*}{ مصبوغ بدون مرسرة } & \multirow{2}{*}{\multicolumn{2}{|c|}{ الثبات للضوء }} \\
\hline 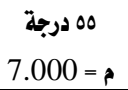 & درجة حرارة الفرفة & & & \\
\hline & & & \multicolumn{2}{|c|}{ مصبوغ بدون مرسرة } \\
\hline & & $* 0.500$ & درجة حرارة الفرفة & مصبوغ \\
\hline & $* 0.500$ & $* * 1.000$ & ل 00 درجة & وممرسر - ل ممر \\
\hline
\end{tabular}

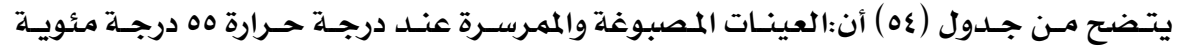

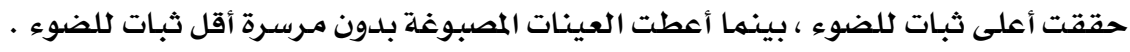




\section{**تقيييم الجودة الكلية لتأثير درجة حرارة الصودا الكاوية على الخواص الطبيعية والميكانيكية للقماش الممرسر}

جدول (هه) تقييم الجودة الكلية لتأثير درجة حرارة الصودا الكاوية على الخواص الطبيعية والميكانيكية للقهماش الممـرسر المصبوغ

\begin{tabular}{|c|c|c|c|c|c|c|c|c|c|c|c|c|c|c|}
\hline \multirow[t]{2}{*}{ الترتيب } & \multirow{2}{*}{ الكقييم } & \multirow{2}{*}{ الضبوs } & \multicolumn{2}{|c|}{ الثبات للعرق ٪ } & \multicolumn{2}{|c|}{ الثبات للإحتكاك } & \multirow{2}{*}{$\begin{array}{c}\text { للفسيل } \\
\text { \% } \\
\end{array}$} & \multicolumn{2}{|c|}{ نسبة الاستطالة } & \multicolumn{2}{|c|}{ قوة الشد ٪ } & \multirow{2}{*}{ | اللون \% } & \multirow[t]{2}{*}{ الاختبار } & \multirow[t]{2}{*}{ العينة } \\
\hline & & & حضي & قلوي & رطب & جاف & & اللحمة & السداء & اللحمة | & |السلاء & & & \\
\hline 3 & 795.00 & 75.00 & 70.00 & 80.00 & 70.00 & 70.00 & 70.00 & 87.50 & 82.50 & 67.50 & 72.50 & 50.00 & 0 & مصبوغ \\
\hline 1 & 933.75 & 81.25 & 80.00 & 80.00 & 80.00 & 70.00 & 80.00 & 95 & 87.50 & 82.50 & 97.50 & 100 & الفرفة & مصببوغ \\
\hline 2 & 813.19 & 87.50 & 80.00 & 80.00 & 60.00 & 80.00 & 70.00 & 65.00 & 70.00 & 57.50 & 90.00 & 73.19 & 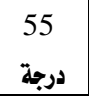 & وممرسر \\
\hline
\end{tabular}

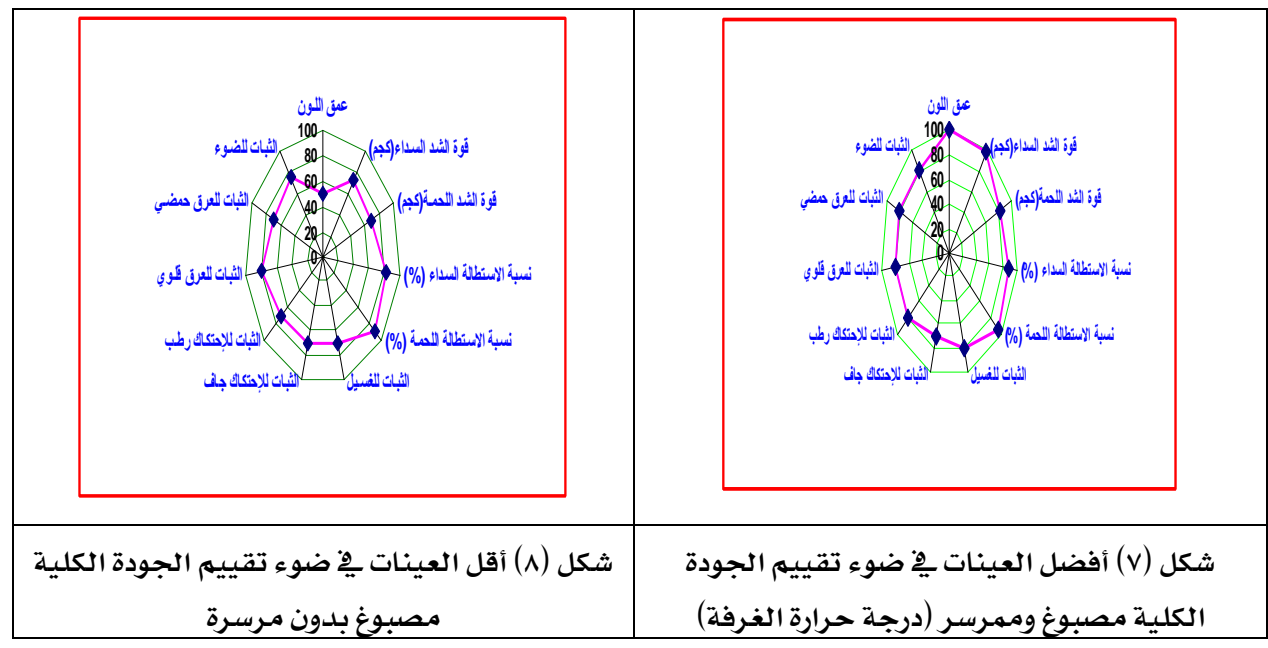

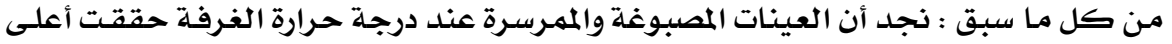

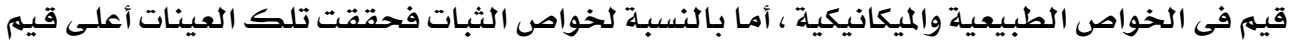

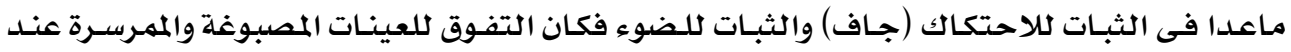

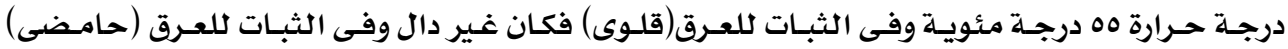

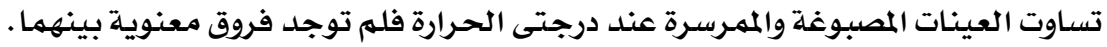


ا - الاستفادة مـن عمليـة المرسرة فى تحسـين خاصية قوة الشد لكلأقمشـة التى تحتاج لذلك . ץ- إجـراء المرسـرة لكلأقهشة المراد صبياغتها حيـث يؤدى ذلك لزيـادة امتصـاص الصبغـة وبالتـالى

$$
\text { زيادة عمق اللون. }
$$

r- تشجيع استخدام الصبغات الطبيعية والعمل على تطوير أسواقها لكونها صديقة للبيئـة . ع- البحث عـن نباتـات جديدة للحصول على تأثيرات لونيـة جديدة ومحاولـة التوصل لـدرجات

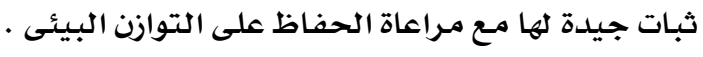
0- التوسـع فى دراسـة الصبـات الطبيعيـة لتحسسين خواصهها وتقليـل اسـتخدام المثبـتات المعدنيـة معها

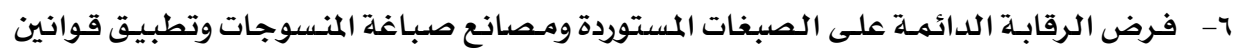
حماية المستهلك والاتفاقيات البيئية المحلية والدولية.

ا - نشوة عبد الرعوف توفيق عبد الحليهم : " تأثير بعض التراكيب البنائيـة للأقمشـة السليولوزيلة والمعالجـات الأولية والتجهيز على بعض خواصها الوظيفية وقابليتها للتنظيف "، رسالة دكتوراه غير منشورة، كليـة

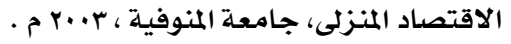
ץ- نبيل عبد البـاسط إبراهيه : " التحضيرات الأولية لكلألياف السليلوزية ومخلوطاتها " ، الاتجاهـات الحديثة فى تحضير وتجهيـز الأليـاف النسـجية ، الطبعـة الثانيـة ، أكاديميـة البحث العلمسى والتكنولوجيـا ، وزارة

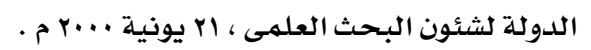

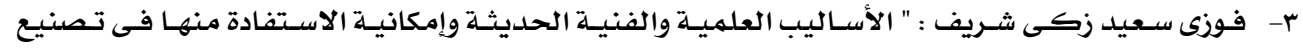

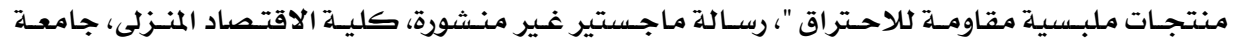
المنوفيـة، ع...

ع - على على حبيث : " نحو وضع خريطة تكنولوجيـة (Roadmap) للصناعة النسجية في مصر " ، مشروع

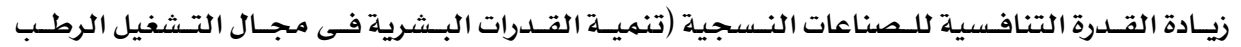
للمنسوجات) ، الجزء الأول ، غرفة الصناعات النسجية المصرية ، القاهرة ، ب. . r م . ه- على على حبـيث : "التطـورفى كيميـاء وتكنولوجيـا المـواد النسسجية "، الاتجاهـات الحديثـة فى تحضير وتجهيز الألياف النسجية ، الطبعة الثانية ، أكاديمية البحث العلمـى والتكنولوجيـا ، وزارة الدولـة لشئون

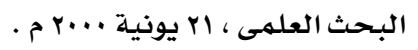

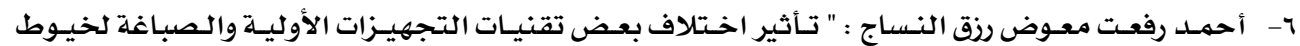
الحياكة القطنيـة والمخلوطلة على خواصهها الوظيفيـة " ، رسـالة ماجستير غير منشورة ، كليـة التربيـة

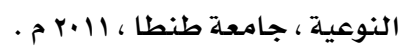

7-Vasugi Raja, Coimbatore, V Subramaniam: "Effect of mercerization on cotton fabrics properties", The Indian Textile Journal, March 2003. 


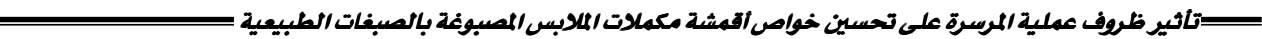

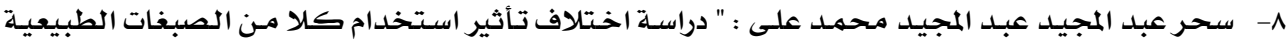
والـصناعيـة على متانـة المنسسوجات المختلفـة " ، رسـالة مـاجستير غـير منسشورة ، كليـة الاقتصـاد المنززلى ،

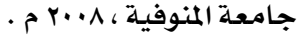

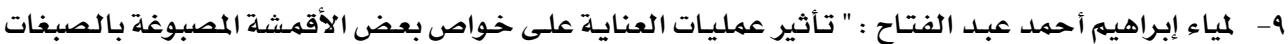

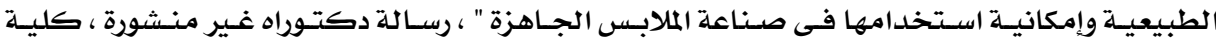
الاقتصساد المنزلى ، جامعة المنوفية ، ع. - م م .

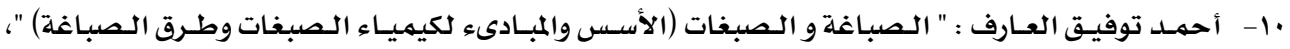
الاتجاهـات الحلديثة فى تحضير وتجهيـز الأليـاف النسسجية ، الطبعـة الثانيـة ، أكاديهيـة البحث العلمـى والتكنولوجيا ، وزارة الدولة لشئون البحث العلهى ، اب يونية ، ... م م .

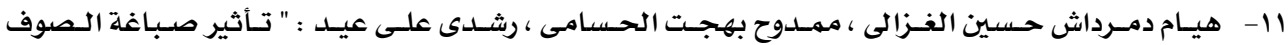
كـالصبيخات الطبيعيـة على بعض خواص الأداء الوظيفى للهنتج النهائى " ، مجلـة الاقتصساد المنزلى ، كلية

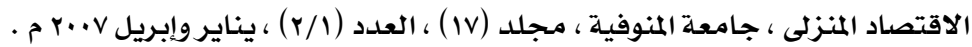

12-Alessandra Carrubba: "Vegetable extracts as natural sources of dyes", Acta horticulture, No. 457, 1998.

13-Jani, M.L.C.: "Present status of natural dyes”, Colourage, Vol 46, July 1999.

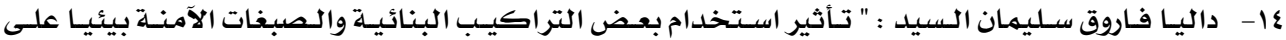
الخواص الوظيفية لأقهشة ملابس الأطفال "،رسالة دكتوراه غير منشورة،كلية الاقتصساد المنزلى،جامعـة

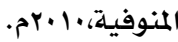

ها - رحاب طه حسين شريدح : " تأثير اختلاف عدة الأقمشة الأطلسيـة المنتجـة ببعض أسـاليب الغزل المختلفـة على قابليتها للتجهيزوالصبـاغة الصديقة للبيئة " ، رسـالة مـاجستير غير منشورة ، كليـة التربية النوعيـة

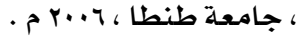

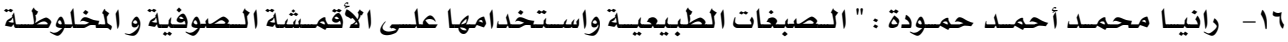
المستخدمة فى مـلابس الأطفال " ، رسالة مـاجستير غير منشورة ، كليـة الاقتصاد المنزلى ، جامعة المنوفيـة $\cdot+r \cdot r^{\prime}$

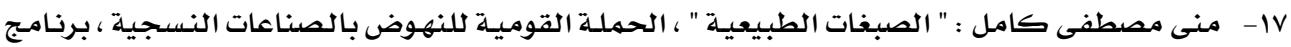
تنهيـة القوى البشريـة ، أكاديهية البحث العلهى والتكنولوجيا ، المركز القومى للبحـوث ، الجـزء الثانى ، $\cdot+r \cdot \varepsilon$

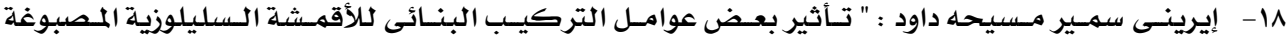

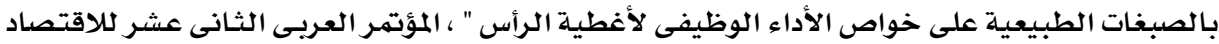

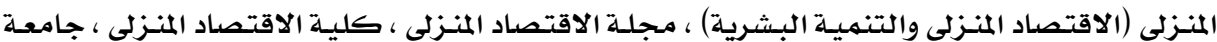

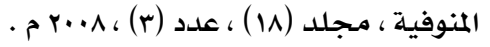

19-Sanad , Suzan H. , A.A.Ramadam : " Effect of dyeing cotton fabrics with natural dye (Henna) and synthetic dye (Remazol blue) on some mechanical 
properties and stability to light exposure " , cotton research institute , Giza , 2004.

•r- رثدى على أحمد عيد ، حنان حسنى يشار ، رشا محمـد نجيب مبـارك : " إمكانية الاستفادة مـن التطريز

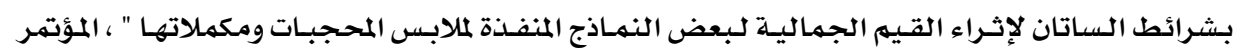

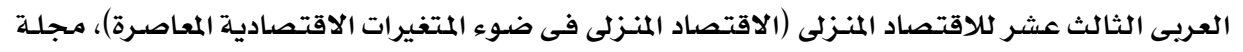

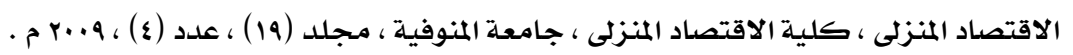

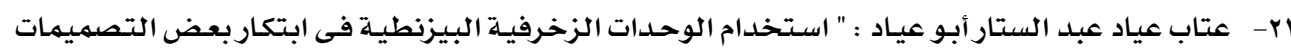

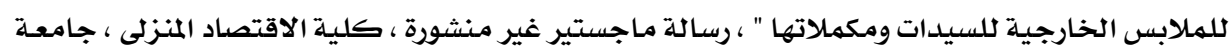

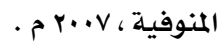

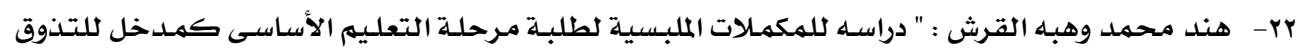

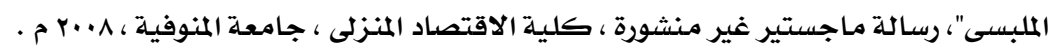

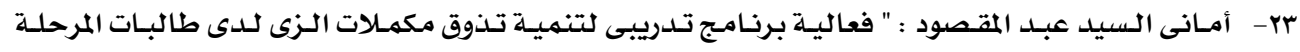

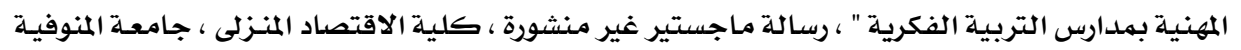
- r...9، §ץ- منار محمد رشاد معروف محمد : " إمكانية الاستفادة من الخواص الحرارية للأقمشة الصناعية فى إثراء

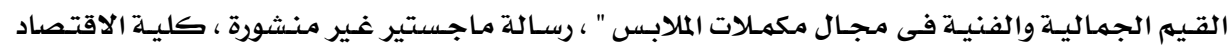

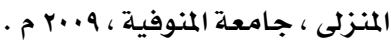

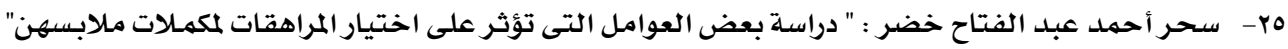

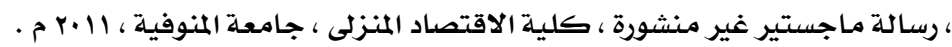

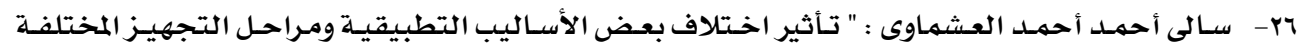

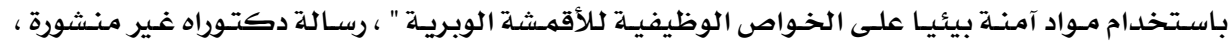
كلية الاقتصاد المنزلى، جامعة المنوفية ، ه . Y م . 
ב-تأثير ظروف عملية المرسرة على تحسين خواص أقمشة مكملات /لمابس المصبوغة بالصبغات الطبيعية

The Effect Of Conditions Mercerization Process To Improve The Properties Of Clothing Accessories Fabrics Which Dyed By Natural Dyes

Dr. Assmaa Samy Abd-ELaty * Dr. Rania Mohemed Ahmed ${ }^{* *}$

\section{Abstract}

Highlights the great importance of the textile industry and knitting as well as the finishing industry (including desizing, scouring, bleaching, mercerization(accourding to the type of material and the final product), dyeing, printing, finishing) in meeting the needs of the garment industry, and expand prosperity and enable them to compete in domestic and international markets, and the concomitantof high added value, as well as by raising the efficiency and level of processing industry exports a great deal of value-added processed fabrics rather large exported in the form of raw material.It is necessary to comply with the legislation on textiles following the environmentally cleaner production methods to maintain a presence in the market and increase competitiveness.

The phenomenon of finery phenomenon humanitarian impression by man since ancient times it is difficult to determine the date of this relationship which has evolved succession times and in different regions and also the impact factors of civilization-changing, but something remains constant and connected no matter how different these factors, namely the human desire to decking. And clothing accessories with significant economic value where it can be changed by using a single uniform on more than one occasion, and the accessories are the final touch that without it the external appearance of the individual not completed, and therefore clothing accessories phenomenon worthy of study and research.

So interested in current research studying the effect of conditions mercerization process to improve the properties of clothing accessories

* Lecturers: Clothes and Textiles, Home Economics Department, Faculty of Specific Education, Tanta University

A* Ass. Prof. of Clothes and Textile, Home Economics Department, Faculty of Specific

Education, Tanta University 
fabrics which dyed by natural dyes and in order to: Identify the effect metal mordants on fabrics mercerized and dyed by natural dyes, to reach the most appropriate (concentration of soda caustic, time to the process of immersion in caustic soda, temperature of caustic soda) achieves the highest quality of fabrics under research, recognize the difference between samples mercerized and dyed and both of samples mercerized without dye and dyed samples without merce.

Testing has been made: tensile strength, percentage elongation, color depth, Tests for color fastness to (washing, rubbing (dry, wet), perspiration (alkaline, acidic), light) and then was to use the method statistical manner and conduct quality assessment of the results of these tests, and the most important the findings of the research:

1- Samples mercerized and dyed using Chrome mordant achieved the highest values of the measured properties.

2- Samples dyed and mercerized using caustic soda concentration of 250 $\mathrm{g} / \mathrm{l}$ achieved the highest values of the measured properties.

3- Samples dyed and mercerized using immersion time in soda 60 seconds achieved the highest values of the measured properties.

4- Samples dyed and mercerized at room temperature achieved the highest values of the physical properties and mechanical, but for the properties of stability those samples achieved highest values except in the color fastness to rubbing (dry) and color fastness to light was the superiority of the samples dyed and mercerized at a temperature of $55^{\circ} \mathrm{C}$ and in the color fastness to perspiration (alkaline) was not D. At the color fastness to perspiration (acidic) samples dyed and mercerized were equal in both degree of the heat where did no significant differences between them. 